UNIVERSIDADE DE SÃO PAULO - USP

Programa de Ciência Ambiental - Procam

NAOKA SERA FURUITI

\title{
A atuação do Ministério Público no \\ LICENCIAMENTO AMBIENTAL DE \\ EMPREENDIMENTOS DE GERAÇÃO DE ENERGIA
}

SÃo PAULO

2009 
NAOKA SERA FURUITI

\title{
A atuaÇão do Ministério Público no \\ LICENCIAMENTO AMBIENTAL DE EMPREENDIMENTOS DE GERAÇÃO DE ENERGIA
}

Dissertação apresentada ao Programa de PósGraduação em Ciência Ambiental da Universidade de São Paulo para a obtenção do título de Mestre em Ciência Ambiental.

Orientador: Prof. Dr. Pedro Leite da Silva Dias

\author{
SÃo PAUlO
}

2009 
AUTORIZO A REPRODUÇÃO E DIVULGAÇÃO TOTAL OU PARCIAL DESTE TRABALHO, POR QUALQUER MEIO CONVENCIONAL OU ELETRÔNICO, PARA FINS DE ESTUDO E PESQUISA, DESDE QUE CITADA A FONTE.

Catalogação na Publicação

Programa de Ciência Ambiental da Universidade de São Paulo

Sera Furuiti, Naoka

A atuação do Ministério Público no licenciamento ambiental de empreendimentos de geração de energia / Naoka Sera Furuiti; orientador Pedro Leite da Silva Dias - São Paulo, 2009.

167 f. : fig.

Dissertação (Mestrado - Programa de Pós-gradução em Ciência Ambiental) Programa de Ciência Ambiental da Universidade de São Paulo.

1. Ministério Público. 2. Licenciamento ambiental - estudo de impacto ambiental. 3. Direito ambiental. 4. Políticas de energia. I. Título. 
SERA FURUITI, Naoka. A atuação do Ministério Público no licenciamento ambiental de empreendimentos de geração de energia. 2009. 167 f. Dissertação (mestrado) - Programa de Ciência Ambiental, Universidade de São Paulo, São Paulo.

\title{
ERRATA
}

\author{
Folha Linha Onde se lê \\ Leia-se
}




\title{
FOLHA DE APROVAÇÃO
}

\section{Naoka Sera Furuiti}

A atuação do Ministério Público no licenciamento ambiental de empreendimentos de geração de energia

Dissertação apresentada ao Programa de Ciência Ambiental da Universidade de São Paulo para a obtenção do título de Mestre.

Aprovada em:

\author{
Banca Examinadora
}

Prof. Dr. Pedro Leite da Silva Dias

Instituto de Astronomia, Geofísica e

Ciências Atmosféricas - USP

Assinatura:

Prof. Dr. Wagner Costa Ribeiro

Departamento de Geografia -

Faculdade de Filosofia, Letras e

Ciências Humanas - USP

Assinatura:

Profa. Dra. Cristiane Derani

Universidade Católica de Santos

- UNISANTOS

Assinatura: 
Para Ken, Lie e Edson. Sempre. 


\section{AGRADECIMENTOS}

Ao Professor Pedro Leite da Silva Dias, para quem não há palavras para demonstrar a gratidão pela confiança, pelo incentivo, pelos ensinamentos para a pesquisa e para a vida, por saber tanto e ainda assim contagiar com a sua incessante sede de saber mais.

Ao Professor Wagner Costa Ribeiro, por ter ensinado, como mestre e cidadão ambiental, a pensar nas inquietações sobre o mundo atual e fazê-las refletir na pesquisa acadêmica.

À Professora Cristiane Derani, por ter iluminado, com seu vasto conhecimento e sua visão crítica, o caminho ético e seguro do Direito Ambiental dentro da pesquisa interdisciplinar.

À Professora Maria Assunção da Silva Dias, pelo apoio direto e indireto na realização desta pesquisa.

Ao Dr. Carlos Alberto Salles pela costumeira atenção e, juntamente com o Dr. Daniel Fink, pela dignidade com que representa o Ministério Público do Estado de São Paulo. E ao Dr. Clério Rodrigues da Costa, por fazer o mesmo pelo Estado.

Aos administradores públicos e professores Fernando Rei, Germano Seara Filho e José Goldemberg, pela contribuição a esta pesquisa e à gestão do meio ambiente paulista.

Aos meus pais, aos meus irmãos e às minhas cunhadas, aos quais devo os meus primeiros passos na vida.

Aos meus sobrinhos, por terem-me feito acreditar que a humanidade tem futuro.

Aos meus amigos e colegas, especialmente à Neusa Seincman, que me acompanha desde o processo seletivo para o Mestrado, à Ana Claudia Franco, que me subsidiou com informações valiosas, e à Rebeca Lovro da Silva, pelo apoio no escritório.

Ao Programa de Ciência Ambiental da USP e àqueles que dela fazem parte, pela oportunidade de realização do curso de Mestrado. 
"... os direitos não nascem todos de uma vez. Nascem quando devem ou podem nascer. Nascem quando o aumento do poder do homem sobre o homem - que acompanha inevitavelmente o progresso técnico, isto é, o progresso da capacidade do homem de dominar a natureza e os outros homens - ou cria novas ameaças à liberdade do indivíduo ou permite novos remédios para as suas indigências: ameaças que são enfrentadas através de demandas de limitações do poder; remédios que são providenciados através da exigência de que o mesmo poder intervenha de modo protetor."

Norberto Bobbio 


\section{RESUMO}

SERA FURUITI, Naoka. A atuação do Ministério Público no licenciamento ambiental de empreendimentos de geração de energia. 2009. 167 f. Dissertação (mestrado) - Programa de Ciência Ambiental, Universidade de São Paulo, São Paulo, 2009.

Este trabalho tem por objetivo analisar como o Ministério Público brasileiro tem exercido a função inovadora que lhe foi atribuída pela Constituição Federal de 1988 para zelar pelo efetivo respeito dos Poderes Públicos e dos serviços de relevância pública ao direito constitucional do meio ambiente ecologicamente equilibrado, especificamente no tocante à sua atuação em processos de licenciamento ambiental. Para tal fim, adotou-se a metodologia de estudo de caso, com o levantamento de dados junto aos órgãos oficiais (Ministério Público do Estado de São Paulo, Secretaria de Meio Ambiente do Estado de São Paulo, Poder Judiciário, Ministério de Minas e Energia, Agência Nacional de Energia e Eletricidade) e entrevistas com atores representativos dos segmentos envolvidos ou com o caso estudado, associado à revisão legislativa e bibliográfica. $\mathrm{O}$ caso concreto foi escolhido a partir da delimitação do recorte geográfico e temporal: as pesquisas limitaram-se ao Estado de São Paulo, aos processos de licenciamento conduzidos pela Secretaria de Meio Ambiente do Estado de São Paulo e à atuação do Ministério Público do Estado de São Paulo, no período compreendido entre 2001 e 2006. Verificou-se que, especialmente a partir da Constituição Federal de 1988, as atribuições e prerrogativas do Ministério Público brasileiro, sem similares no sistema político de outros Estados ocidentais, conferiram-lhe o papel de promover a coercibilidade das normas de proteção ambiental e, ainda, atuar em foro alternativo ao Poder Judiciário para o gerenciamento de conflitos ambientais. Restando incontroversa a relevância de sua atuação na proteção do meio ambiente, constatou-se que, no tocante à fiscalização de processos de licenciamento ambiental conduzidos pelo órgão licenciador, na prática essa atuação acaba por ensejar novos conflitos com a Administração Pública, com reflexos sobre os atores envolvidos com o projeto sob discussão no processo de licenciamento ambiental. Propostas para seu equacionamento são analisadas neste trabalho.

Palavras-chave: Ministério Público; Licenciamento ambiental - estudo de impacto ambiental; Direito ambiental; Políticas de Energia. 


\begin{abstract}
SERA FURUITI, Naoka. The District Attorney's action on environmental licencing of energy generation projects. 2009. 167 f. Dissertation (Masters degree) - Post Graduation Program in Environmental Science, University of São Paulo, São Paulo, 2009.

This research seeks to evaluate how the District Attorney Office of Brazil ("Ministério Público") has been performing the innovating function of watching over the effective respect of the Public Power and relevant public services regarding the constitutionally right to an ecologically-balanced environment, attributed to it by the Federal Constitution of 1988, wish specific focus on environmental licensing processes. With such purpose, based on the case study methodology, a collection of data within official bodies (District Attorney of São Paulo State, Environmental Protection Agency of the State of São Paulo, Judiciary Power, Mine and Electricity Ministry, National Agency of Energy and Electricity) has been performed, as well as interviews with representative players of the involved segments, legislative and bibliographic reviews. Choice of case study was determined by the scope definition of space and time: researches were limited to the State of São Paulo, to the environmental licensing procedures conducted by the State Environmental Protection Agency and the performance of the District Attorney of São Paulo State, in the period comprehended between 2001 and 2006. Main findings include the fact that, due to the unique role of responsibilities and authority given to the District Attorney Office of Brazil by the Federal Constitution of 1988, it is responsible to promote the effectiveness of the environmental protection legislation as well as acting alternatively to the Judiciary System in the resolution of environmentally-based conflicts and the uncontroversial relevance of its role on the protection of the environment. However, when analyzing its role on the monitoring of environmental licensing processes conducted by the administrative licensing authorities, it was also identified that new conflicts with the Public Administration arise, with reflexes on all actors involved in the environmental licensing process. Purposes for its solution are analyzed in this work.
\end{abstract}

Keywords: District Attorney Office; Environmental licensing - environmental impact study; Environmental law; Energy policies. 


\section{SIGLAS E ABREVIATURAS}

ANEEL Agência Nacional de Energia e Eletricidade

CAO Centro de Apoio Operacional do Ministério Público do Estado de São Paulo

CAO-UMA Centro de Apoio Operacional de Urbanismo e Meio Ambiente do Ministério Público do Estado de São Paulo

CETESB Companhia de Tecnologia de Saneamento Ambiental (Companhia Ambiental do Estado de São Paulo desde 07.08.2009)

CF-88 Constituição da República Federativa do Brasil de 1988

CONAMA Conselho Nacional do Meio Ambiente

CONSEMA Conselho Estadual do Meio Ambiente

DAIA Departamento de Avaliação de Impacto Ambiental

EIA Estudo de Impacto Ambiental

EIA-RIMA Estudo de Impacto Ambiental e respectivo Relatório de Impacto ao Meio Ambiente

IAG-USP Instituto de Astronomia, Geofísica e Ciências Atmosféricas da USP

IBAMA Instituto Brasileiro do Meio Ambiente e Recursos Naturais Renováveis

IBGE Instituto Brasileiro de Geografia e Estatística

INPE Instituto Nacional de Pesquisas Espaciais

MME Ministério de Minas e Energia

MP Ministério Público

MPE-SP Ministério Público do Estado de São Paulo

ONG Organização Não-governamental

$\mathrm{PCH} \quad$ Pequena Central Hidrelétrica

PPT Programa Prioritário de Termeletricidade

PRAD Plano de Recuperação de Áreas Degradadas

RAMS Regional Atmospheric Modeling System

RAP Relatório de Avaliação Preliminar

RRA Relatório de Regularização Ambiental

RIMA Relatório de Impacto ao Meio Ambiente

SMA Secretaria de Meio Ambiente do Estado de São Paulo

TAC Termo de Compromisso de Ajustamento de Conduta

UHE Usina Hidroelétrica

USP Universidade de São Paulo

UTE Usina Termoelétrica 


\section{LISTA DE ILUSTRAÇÕES}

\begin{tabular}{|c|c|c|}
\hline Figura 1 & $\begin{array}{l}\text { Capacidade de geração de energia elétrica instalada no País classificada } \\
\text { por Estado }\end{array}$ & 22 \\
\hline Figura 2 & $\begin{array}{l}\text { Dados da atuação do Ministério Público do Estado de São Paulo na } \\
\text { defesa do meio ambiente }\end{array}$ & 31 \\
\hline Figura 3 & $\begin{array}{l}\text { Estrutura organizacional da Secretaria de Meio Ambiente do Estado de } \\
\text { São Paulo até o advento do Decreto 54.653, de 05.08.2009 }\end{array}$ & 55 \\
\hline Figura 4 & $\begin{array}{l}\text { Pedidos protocolados entre 1997-2006 no Departamento de Avaliação } \\
\text { de Impacto Ambiental classificados por categoria }\end{array}$ & 102 \\
\hline Figura 5 & $\begin{array}{l}\text { Pedidos protocolados entre 1997-2006 no Departamento de Avaliação } \\
\text { de Impacto Ambiental classificados por matriz energética }\end{array}$ & 103 \\
\hline Figura 6 & $\begin{array}{l}\text { Pedidos protocolados entre 1997-2006 no Departamento de Avaliação } \\
\text { de Impacto Ambiental classificados pelo ano de início do processo }\end{array}$ & 103 \\
\hline
\end{tabular}




\section{LISTA DE ANEXOS}

\begin{tabular}{|l|l|c|}
\hline Anexo 1 & $\begin{array}{l}\text { Dados quantitativos da atuação do Ministério Público do Estado de São } \\
\text { Paulo na tutela do meio ambiente }\end{array}$ & 151 \\
\hline Anexo 2 & $\begin{array}{l}\text { Estrutura organizacional da Secretaria de Meio Ambiente } \\
\text { (após o advento do Decreto Estadual 54.653, de 05.08.2009) }\end{array}$ & 152 \\
\hline Anexo 3 & $\begin{array}{l}\text { Síntese do processo de licenciamento da Usina Termoelétrica de Santa } \\
\text { Branca na Secretaria de Meio Ambiente do Estado de São Paulo }\end{array}$ & 153 \\
\hline Anexo 4 & \begin{tabular}{l} 
Síntese do andamento processual da Ação Civil Pública no 42/00 \\
\hline Anexo 5
\end{tabular} & Síntese do andamento processual da Ação Civil Pública n ${ }^{\circ}$ 505/01 \\
\hline
\end{tabular}




\section{SUMÁRIO}

\begin{tabular}{|c|c|}
\hline 1. INTRODUÇÃO: EXPLICITAÇÃO DOS OBJETIVOS & 15 \\
\hline 1.1 DELIMITAÇÃO DA PESQUISA & 19 \\
\hline 1.1.1 Limite material & 20 \\
\hline 1.1.2 Limite espacial & 22 \\
\hline 1.1.3 Limite temporal & 24 \\
\hline 1.2 PROCEDIMENTO METODOLÓGICO & 26 \\
\hline 1.3 O ENFOQUE INTERDISCIPLINAR & 28 \\
\hline 1.4 RELEVÂNCIA DO TEMA & 31 \\
\hline 2. CONTEXTUALIZAÇÃO & 34 \\
\hline 2.1 CONFLITOS AMBIENTAIS E O DIREITO & 34 \\
\hline 2.2 PROTEÇÃO AMBIENTAL EM OUTROS PAÍSES & 38 \\
\hline 2.3 POLÍTICAS DE ENERGIA E OS CONFLITOS AMBIENTAIS & 43 \\
\hline 3. LICENCIAMENTO AMBIENTAL E ESTUDO DE IMPACTO AMBIENTAL & 49 \\
\hline 3.1 PREVISÃO LEGAL DO LICENCIAMENTO E DO ESTUDO DE IMPACTO AMBIENTAL & 49 \\
\hline 3.2 O PROCESSO DE LICENCIAMENTO AMBIENTAL NO ESTADO DE SÃO PAULO & 55 \\
\hline 4. O MINISTÉRIO PÚBLICO NA TUTELA DO MEIO AMBIENTE & 64 \\
\hline 4.1 EVOLUÇÃO HISTÓRICA E O MINISTÉRIO PÚBLICO BRASILEIRO ATUAL & 64 \\
\hline 4.1.1 Princípios institucionais e mecanismos de controle & 68 \\
\hline 4.1.2 Instrumentos judiciais e extraprocessuais do Ministério Público & 72 \\
\hline 4.2 A ESTRUTURA INSTITUCIONAL DO MINISTÉRIO PÚBLICO DO ESTADO DE SÃO PAULO & 77 \\
\hline 4.3 BASE JURÍDICA PARA A ATUAÇÃO NO LICENCIAMENTO AMBIENTAL & 83 \\
\hline $\begin{array}{l}\text { 5.MECANISMOS DE CONTROLE DO LICENCIAMENTO AMBIENTAL E } \\
\text { DO ESTUDO DE IMPACTO AMBIENTAL }\end{array}$ & 89 \\
\hline 6. COLETA DE DADOS & 101 \\
\hline $\begin{array}{l}\text { 6.1 DADOS DE LICENCIAMENTO AMBIENTAL DE EMPREENDIMENTO DE GERAÇÃO DE } \\
\text { ENERGIA- SECRETARIA DE MEIO AMBIENTE DO ESTADO DE SÃO PAULO }\end{array}$ & 101 \\
\hline 6.2 DESCRIÇÃO DO PROJETO DA USINA TERMOELÉTRICA DE SANTA BRANCA & 106 \\
\hline 6.3 O LICENCIAMENTO AMBIENTAL DA USINA TERMOELÉTRICA DE SANTA BRANCA & 110 \\
\hline 6.4 INTERVENÇÕES JUDICIAIS NO LICENCIAMENTO AMBIENTAL DA UTE SANTA BRANCA & 122 \\
\hline 6.4.1 Ação civil pública $\mathrm{n}^{\circ} 40 / 00$ & 123 \\
\hline 6.4.2 Ação civil pública $\mathrm{n}^{\circ} 505 / 01$ & 125 \\
\hline 7. ENTREVISTAS & 129 \\
\hline 8. ANÁLISE E CONCLUSÕES & 131 \\
\hline REFERÊNCIAS BIBLIOGRÁFICAS & 138 \\
\hline NORMAS REFERENCIADAS & 146 \\
\hline ANEXOS & 151 \\
\hline
\end{tabular}




\section{INTRODUÇÃO: EXPLICITAÇÃO DOS OBJETIVOS}

Este trabalho tem por objetivo analisar como o Ministério Público brasileiro (MP) tem exercido a função inovadora que lhe foi atribuída pela Constituição Federal de 1988 (CF-88) para zelar pelo efetivo respeito dos Poderes Públicos e dos serviços de relevância pública ao direito constitucional do meio ambiente ecologicamente equilibrado ${ }^{1}$.

Com enfoque na fiscalização de processos de licenciamento ambiental de empreendimentos de geração de energia elétrica, pretende-se contrapor atribuições administrativas e jurisdicionais no gerenciamento dos conflitos entre, por um lado, a demanda crescente de energia estimada pelos órgãos oficiais, e por outro, a proteção do meio ambiente.

Perseguindo tal objetivo, o trabalho deteve-se em descrever institucionalmente o MP - em particular o Ministério Público do Estado de São Paulo (MPE-SP) -, refletir sobre a complexidade técnico-jurídica do licenciamento ambiental e do Estudo de Impacto Ambiental (EIA) e respectivo Relatório de Impacto ao Meio Ambiente (RIMA), e, subsidiariamente, levantar dados sobre processos de licenciamento ambiental de empreendimentos de geração de energia conduzidos pela Secretaria de Meio Ambiente do Estado de São Paulo (SMA).

Adotou-se a metodologia de estudo de caso, com o levantamento de dados junto aos órgãos oficiais - MPE-SP, SMA, Poder Judiciário, Ministério de Minas e Energia (MME), Agência Nacional de Energia e Eletricidade (ANEEL) - e entrevistas com atores representativos dos segmentos envolvidos, associados à revisão bibliográfica.

\footnotetext{
${ }^{1}$ Conforme previsto na CF-88, artigo 129, inciso II (BRASIL, 1988).
} 
O caso concreto foi escolhido a partir da delimitação do recorte geográfico e temporal: as pesquisas limitaram-se ao Estado de São Paulo, aos processos de licenciamento conduzidos pela SMA e à atuação do MPE-SP, no período compreendido entre 2001 e 2006.

Dados que extrapolem essas delimitações estão referenciados apenas para efeito de contextualização ou quando se demonstraram relevantes para extrair informações necessárias à adequada percepção dos fatos para o presente estudo.

O trabalho foi estruturado para inicialmente apresentar, de forma isolada, em capítulos independentes, os elementos envolvidos no objeto de estudo, para ao final contrapô-los, em uma análise crítica da fiscalização exercida pelo MP sobre o licenciamento ambiental conduzido pela Administração Pública.

Assim, na parte introdutória, está apresentada a delimitação das premissas da pesquisa científica: o que (limite material), onde (limite espacial), quando (limite temporal), como (procedimento metodológico) e por que (relevância do tema).

Para alicerçar as bases de conhecimento relevantes para o desenvolvimento do estudo proposto, o capítulo de contextualização trata dos conflitos envolvendo a proteção do meio ambiente e a utilização de seus recursos, da proteção ambiental em outros países (inclusive buscando identificar funções similares às do MP no Direito Comparado) e do cenário de demanda e geração de energia elétrica para, então, inserir a crise energética de 2001 e as políticas de energia dela resultantes, com seus reflexos no licenciamento ambiental. 
O terceiro e o quarto capítulos avaliam os tópicos centrais da pesquisa: respectivamente, o licenciamento ambiental e o EIA, e depois o MP, com detalhamento sobre a estrutura e o funcionamento da SMA e do MPE-SP. Concluída a análise individualizada, o quinto capítulo consiste numa análise conjunta dos tópicos principais, identificando as circunstâncias previstas estruturalmente para a intervenção do MP no processo de licenciamento ambiental.

No sexto capítulo tem-se a análise dos dados levantados na SMA e no Poder Judiciário (complementados por entrevistas), que têm relação com o caso estudado em profundidade - a Central Termoelétrica de Santa Branca (UTE Santa Branca) -, cuja licença ambiental emitida pela SMA foi cancelada pelo Poder Judiciário por iniciativa do MPE-SP.

Sendo assim, nesse capítulo é apresentada a descrição do projeto da UTE Santa Branca, a sua inserção na política de gestão da crise do déficit energético, as etapas do licenciamento ambiental às quais foi submetido junto à SMA (especialmente aquelas em que houve participação do MP - ou que, pelo modelo de licenciamento adotado pela SMA, estaria prevista sua participação) e as intervenções na esfera judicial propostas pelo MPE-SP.

Como as questões alegadas como impeditivas para o licenciamento ambiental da UTE Santa Branca e que foram submetidas à apreciação do Poder Judiciário pelo MPE-SP tiveram suas decisões definitivas proferidas antes do final deste estudo ${ }^{2}$, foi possível a avaliação completa do caso, do protocolo do pedido de licenciamento na SMA até o encerramento das pendências judiciais relacionadas a esse processo administrativo.

\footnotetext{
${ }^{2}$ Conforme será analisado no item 6.4, a última decisão aplicável ao licenciamento ambiental da UTE Santa Branca transitou em julgado em fevereiro de 2009 e o respectivo processo foi arquivado em 06.07.2009.
} 
Ao longo desse período, ocorreram alterações estruturais na SMA e na Companhia de Tecnologia de Saneamento Ambiental (Cetesb), atualmente denominada Companhia Ambiental do Estado de São Paulo, tendo sido mantida a mesma sigla.

O mesmo ocorreu com o MPE-SP, no tocante ao seu Centro de Apoio Operacional (CAO). No período em estudo, havia o Centro de Apoio Operacional de Urbanismo e Meio Ambiente (CAO-UMA), cujas atribuições passaram para uma coordenadoria dentro do CAO Cível e para o Centro de Apoio Operacional à Execução.

Para efeito metodológico, a análise realizada baseou-se na estrutura existente à época em que o licenciamento ambiental do projeto UTE Santa Branca estava em curso, ao mesmo tempo em que as alterações implantadas estão devidamente referenciadas ao longo do trabalho.

Dado o enfoque interdisciplinar e, por conseguinte, sua preocupação em contribuir para mais do que uma área específica do conhecimento, procurou-se oferecer explicações sobre conceitos que, embora cotidianos para leitores com formação em determinadas ciências, apresentar-se-iam compreensivelmente estranhos para outros de formações diversas, o que naturalmente lhes traria dificuldades para a correta compreensão do trabalho ora apresentado.

Ainda nesta parte introdutória, cabe mencionar que o presente trabalho insere-se na linha de pesquisa "Planejamento, Conservação e Desenvolvimento Socioambiental" do Programa de Pós-graduação em Ciência Ambiental da Universidade de São Paulo. 


\subsection{DELIMITAÇÃo DA PESQUISA}

Expandindo a clássica atuação na esfera persecutória penal, a CF-88 conferiu ao MP atribuições inovadoras que, somadas às suas prerrogativas e aos instrumentos que lhe foram fornecidos pela legislação infraconstitucional - o inquérito civil ${ }^{3}$, o termo de compromisso de ajustamento de conduta (TAC) ${ }^{4}$, a ação civil pública $^{5}$ e a ação de improbidade administrativa ${ }^{6}$ -, tornaram-no uma instituição sem similares dentro do ordenamento pátrio e internacional.

O ponto de partida deste trabalho vem da função institucional introduzida pelo inciso II do artigo 129 do texto constitucional:

Artigo 129, II - zelar pelo efetivo respeito dos Poderes Públicos e dos serviços de relevância pública aos direitos assegurados nesta Constituição, promovendo as medidas necessárias a sua garantia.

Para cumprir essa e outras atribuições inovadoras, a CF-88 conferiu ao MP uma autonomia sem precedentes para, amparado na legitimidade constitucional, fiscalizar a atuação dos órgãos subordinados aos três Poderes (Executivo, Legislativo e Judiciário), dos quais não faz parte, sendo deles independente ${ }^{7}$.

\footnotetext{
${ }^{3}$ Conforme será analisado no item 4.1.2 deste trabalho, o inquérito civil é um procedimento investigatório destinado a apurar a ocorrência de danos efetivos ou potenciais ao meio ambiente (entre outros direitos).

${ }^{4}$ Conforme será analisado no item 4.1.2 deste trabalho, o TAC consiste em um acordo formal entre o causador do dano ambiental e a autoridade ambiental, por meio do qual aquela assume o dever de adequar a sua conduta às exigências legais, sujeito à fiscalização desta, sob pena de incorrer nas sanções previstas no próprio instrumento em caso de descumprimento.

${ }^{5}$ Conforme será analisado no item 4.1.2 deste trabalho, a ação civil pública é uma ação que pode ser proposta pelos entes legitimados, para a finalidade de tutelar, entre outros direitos, a proteção do meio ambiente.

6 A ação de improbidade administrativa consiste em um tipo de ação que visa a apurar e punir a prática de ilícitos na administração pública direta e indireta, além de recuperar os prejuízos em favor dos cofres públicos.

${ }^{7}$ No Título IV ("Da organização dos Poderes") da CF-88, os Poderes Legislativo, Executivo e Judiciário estão apresentados, respectivamente, nos Capítulos I, II e III. Já o MP está no Capítulo IV - "Funções essenciais à justiça”, juntamente com (i) a Advocacia Pública, cuja finalidade é a de representar o Estado judicial e extrajudicialmente, além de prestar consultoria e assessoramento jurídico para o Poder Executivo; (ii) a Advocacia Privada, representada pelos advogados que não seguem carreira pública; e (iii) a Defensoria Pública, que se presta à orientação jurídica e à defesa dos necessitados (BRASIL, 1988).
} 
Com base naquele dispositivo constitucional, conjugado com o artigo 225 , caput da CF-88, que atribui ao Poder Público e à coletividade o dever de defender e preservar o meio ambiente ecologicamente equilibrado $^{8}$, o MP passou a tomar assento em foros de discussão para a formulação de textos normativos e também a acompanhar processos de licenciamento ambiental conduzidos pelos órgãos administrativos de gestão ambiental.

Definidos o ponto de partida e os objetivos que se pretende alcançar, foram delimitados os recortes para a realização da presente pesquisa.

\subsubsection{Limite material}

Será examinado o MP no exercício da atribuição de fiscalizar e controlar a condução de processos de licenciamento ambiental pelos órgãos da Administração Pública, sendo ainda apreciados os conflitos ambientais envolvidos nessa atuação.

Para tanto, serão analisadas a base jurídica do MP para o exercício dessa atribuição, bem como suas diretrizes institucionais, na medida em que estas foram sendo identificadas. Serão ainda objeto de análise os instrumentos extrajudiciais - o inquérito civil e o TAC - de que dispõe essa instituição e que contribuíram para o grande diferencial na sua atuação, tornandoo um ator representativo no gerenciamento de conflitos.

\footnotetext{
${ }^{8}$ CF-88, artigo 225: "Todos têm direito ao meio ambiente ecologicamente equilibrado, bem de uso comum do povo e essencial à sadia qualidade de vida, impondo-se ao Poder Público e à coletividade o dever de defendê-lo e preservá-lo para as presentes e futuras gerações" (BRASIL, 1988).
} 
Esse trabalho abrangerá a análise do MP de forma geral, seguida pela avaliação específica em relação à estrutura e à forma de organização dessa instituição em São Paulo (Estado que se adotou como recorte geográfico), de forma que o destaque será dado ao MPE-SP. Da mesma forma, o CAO e o CAO-UMA referenciados também são aqueles ligados ao MPE-SP.

A pesquisa também se deterá ao licenciamento ambiental e ao EIA, previstos na Política Nacional do Meio Ambiente como seus instrumentos ${ }^{9}$ e, no caso daquele último, elevado à égide constitucional ${ }^{10}$ pela $\mathrm{CF}-88$.

A partir dessa base teórica, o trabalho passará a identificar a atuação daquela instituição, na prática, sobre o licenciamento ambiental de um caso concreto, tanto na esfera judicial quanto na extrajudicial ou administrativa.

Ressalta-se que não serão discutidos neste trabalho temas estritamente jurídicos como os relacionados à legitimidade processual daquela instituição para a tutela de direitos difusos e coletivos, aos instrumentos de tutela coletiva ou à sua relação com o Estado Democrático de Direito, tão intrínsecos às disciplinas do Direito.

Outro recorte da pesquisa sob o ponto de vista material é o foco dado a essa intervenção sobre projetos relacionados à geração de energia elétrica, sendo daí referenciados dados oficiais sobre demanda e capacidade de geração nacional e do Estado de São Paulo.

\footnotetext{
${ }^{9}$ A Política Nacional do Meio Ambiente foi instituída pela Lei Federal 6.938/81, cujo artigo 9 , caput, III e IV, dispõe que: "São instrumentos da Política Nacional do Meio Ambiente: (...) III - a avaliação de impactos ambientais; IV- o licenciamento e a revisão de atividades efetiva ou potencialmente poluidoras" (BRASIL, 1981).

${ }^{10}$ CF-88, artigo 225, § 1: "Para assegurar a efetividade desse direito, incumbe ao Poder Público (...) IV - exigir, na forma da lei, para instalação de obra ou atividade potencialmente causadora de significativa degradação do meio ambiente, estudo prévio de impacto ambiental, a que se dará publicidade" (BRASIL, 1988).
} 


\subsubsection{Limite espacial}

Por questão metodológica, o limite espacial está representado pelo Estado de São Paulo, onde se encontra a maior capacidade de geração de energia elétrica instalada no País, com 521 empreendimentos em operação gerando 22.635.406,90 kW de potência, representando 21,54\% da energia gerada no País, enquanto o Brasil possui no total 2.102 empreendimentos em operação gerando 105.106.201 kW $\mathrm{kW}^{11}$, conforme demonstrado na figura abaixo:

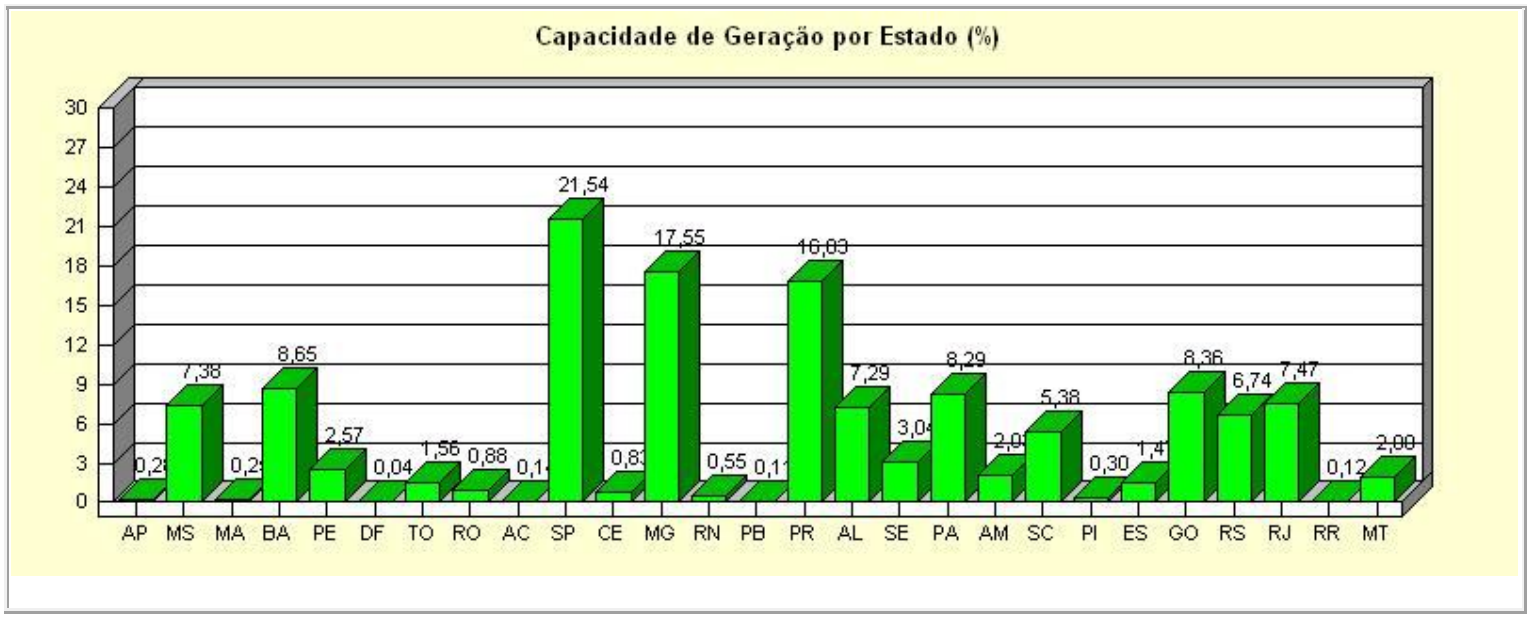

Figura 1 -Capacidade de geração de energia elétrica instalada classificada por Estado (ANEEL, 2009).

Também é o Estado com maior consumo de energia elétrica: enquanto o total nacional em novembro de 2008 foi de $33.766 \mathrm{GWh}^{12}$, no mesmo período, 10.269 GWh (pouco mais de $30 \%$ ) foram consumidos no Estado de São Paulo ${ }^{13}$.

${ }^{11}$ Dados extraídos do Banco de Informações de Geração da ANEEL, nos arquivos "Capacidade Geração Brasil" e "Resumo Estadual" (ANEEL, 2009).

12 Conforme dados da Empresa de Pesquisa Energética (2008), criada pela Lei Federal 10.847/04 como uma empresa pública vinculada ao MME, com a finalidade de desenvolver estudos e pesquisas destinados a subsidiar o planejamento do setor energético brasileiro.

${ }^{13}$ Conforme dados informados pela Secretaria de Saneamento e Energia do Estado de São Paulo (2008). 
Do consumo paulista, $45,7 \%$ foram destinados à classe industrial, $26,2 \%$ ao segmento residencial, $17,4 \%$ à classe comercial e os restantes $10,7 \%$ em outras categorias não discriminadas nos dados oficiais.

Ao mesmo tempo, o Estado de São Paulo é uma das unidades da Federação onde os problemas ambientais são notoriamente acirrados, especialmente considerando-se os níveis de poluição e a apropriação de recursos naturais ${ }^{14}$.

Com a limitação geográfica determinada, este estudo contemplará os processos de licenciamento ambiental conduzidos pela SMA e a atuação do MPE-SP sobre aqueles, tendo em vista a maior representatividade das instituições estaduais no assunto em estudo.

De fato, é competência do órgão estadual realizar o licenciamento ambiental de empreendimentos considerados efetiva ou potencialmente poluidores e a atribuição do órgão federal é suplementar, exceto nos casos excepcionais previstos na legislação em que a atuação do órgão ambiental federal é principal, especialmente naqueles em que haja envolvimento de mais de um estado da Federação ${ }^{15}$. No mais, prepondera a competência do órgão estadual.

\footnotetext{
${ }^{14}$ Essa característica se deve, fundamentalmente, às condições de sua Capital (Município de São Paulo) e das regiões que são próximas a esta, como o Grande ABC, Campinas e Baixada Santista, além de cidades que compreendem aglomerações urbanas em processo de conurbação, como São José dos Campos, Sorocaba e Jundiaí (IBGE, 2007).

${ }^{15}$ Conforme previsto na Política Nacional do Meio Ambiente, Lei Federal 6.938/81, artigo 10: “A construção, instalação, ampliação e funcionamento de estabelecimentos e atividades utilizadoras de recursos ambientais, considerados efetiva e potencialmente poluidores, bem como os capazes, sob qualquer forma, de causar degradação ambiental, dependerão de prévio licenciamento de órgão estadual competente, integrante do Sistema Nacional do Meio Ambiente e do Instituto Brasileiro do Meio Ambiente e Recursos Naturais Renováveis em caráter supletivo, sem prejuízo de outras licenças exigíveis. (...) $\S 4^{\circ}$ Compete ao Instituto Brasileiro do Meio Ambiente e Recursos Naturais Renováveis o licenciamento previsto no caput deste artigo, no caso de atividades e obras com significativo impacto ambiental, de âmbito nacional ou regional" (BRASIL, 1981, grifo nosso). No mesmo sentido, a Resolução do Conselho Nacional do Meio Ambiente 237/97 (1997).
} 
É semelhante o que ocorre com relação ao MP e ao Judiciário: a competência da Justiça

Estadual é residual, ou seja, é tudo o que restar da exclusão das justiças especiais (eleitoral, militar, trabalhista) ${ }^{16}$ e da Justiça Federal ${ }^{17}$. Assim, cabe ao MPE atuar quando não se tratar de atribuição reservada ao MP federal quando a União Federal tiver interesse no feito.

\subsubsection{Limite temporal}

O levantamento documental abrange o período compreendido entre 2001, o ano da crise do déficit energético (que ficou popularmente conhecida como "Apagão"), e 2006, o ano em que se iniciaram os trabalhos de campo, inclusive ${ }^{18}$.

O descompasso entre a capacidade de geração de energia elétrica instalada e o aumento da sua demanda, que acabou resultando na crise energética de 2001, motivou o Governo federal a lançar políticas públicas para estimular a produção urgente de energia, entre as quais se destacou o Programa Prioritário de Termeletricidade (PPT) ${ }^{19}$.

\footnotetext{
${ }^{16}$ As chamadas justiças especiais estão descritas na CF-88: Justiça do Trabalho, que dirime as relações de trabalho (artigos 111-117); Justiça Eleitoral, que trata das questões eleitorais (artigos 118-121) e Justiça Militar, à qual compete processar e julgar os crimes militares (artigos 122-124) (BRASIL, 1988).

${ }_{17}$ A Justiça Federal é regulamentada pela Lei Federal 5.010/66, tendo como competência tratar de casos que envolvem os entes federais e questões de soberania nacional, estando o seu rol de competência descrito de forma taxativa no artigo 109 da CF-88 e, como tal, não pode ser complementado, ampliado ou reduzido a não ser por emenda constitucional (COSTA MACHADO, 2008).

${ }^{18}$ Em situações excepcionais, alguns dados que fogem dessa delimitação temporal foram considerados nesta pesquisa, de forma referenciada, quando pertinentes a fatos que se demonstraram relevantes para contemplar a integralidade do estudo proposto ou para permitir a contextualização com a atualidade dos fatos descritos no presente trabalho.

${ }^{19}$ O PPT foi instituído pelo Decreto Federal 3.371/00 (BRASIL, 2000).
} 
Também devido à então farta disponibilidade de gás natural ${ }^{20}$, as termelétricas foram consideradas a alternativa mais rápida e efetiva para suprir a carência de energia na época, em comparação com a predominante matriz hidroelétrica do País.

Por essa razão, foram editadas medidas provisórias $^{21}$, por sua vez regulamentadas por resolução administrativa ${ }^{22}$, as quais, entre outras providências, previram diferenciações no processo de licenciamento ambiental de empreendimentos de geração de energia elétrica, visando à agilidade na emissão das respectivas licenças ambientais.

Dentro desse contexto político, 2001 foi o ano em que o plenário do Conselho Estadual de Meio Ambiente (Consema) apreciou pela primeira $v^{23} z^{23}$ viabilidade ambiental de uma usina termoelétrica no Estado de São Paulo ${ }^{24}$.

Ressalta-se que a delimitação da pesquisa para o período e para o espaço geográfico definidos não significa que seus resultados se circunscrevem a determinadas datas e locais. Pela própria metodologia do estudo de caso, a proposta é que, a partir de um recorte bem definido, seus resultados extrapolem para outras situações de tempo e espaço, em conformidade com a generalização analítica preceituada por Yin $(2005)^{25}$.

\footnotetext{
${ }^{20}$ Por conta do contrato de compra e venda entre Yacimientos Petroliferos Fiscales Bolivianos e Petrobras S.A celebrado em agosto de 1996, conforme será detalhado no item 2.3.

${ }^{21}$ Conforme será analisado no item 2.3, as medidas emergenciais para a gestão da crise energética foram previstas inicialmente pela Medida Provisória 2.147/01 e as que a sucederam.

${ }^{22}$ Conforme será analisado no item 2.3, foi publicada a Resolução Conama 279/01 para regulamentar as Medidas Provisórias de gestão da crise energética de 2001 (Medida Provisória 2.147/01 e as que a sucederam).

${ }^{23}$ O Consema foi criado pelo Decreto Estadual 20.903/83. Portanto, esse Conselho existe desde antes da criação da SMA, criada em 1996. Os dados relacionados às votações foram obtidas no banco de dados das resoluções e moções emanadas por aquele conselho desde a sua criação.

${ }^{24}$ Conforme será analisado no item 6.1, a primeira UTE cuja viabilidade ambiental foi discutida pelo Consema foi a da Central de Co-geração da Baixada Santista - CCBS em 29.01.2001, sendo que no mesmo ano seguiramse as da Central de Cogeração Capuava e Usina Termelétrica Duke 1-UTE D1.

${ }^{25}$ Conforme será visto no item 1.2 , pela generalização analítica, o pesquisador pode gerar proposições teóricas que extrapolam para outros contextos.
} 


\subsection{Procedimento Metodológico}

A metodologia adotada para esta pesquisa é a do estudo de caso, por preencher os requisitos apontados por Yin (2005): (i) o fato de as perguntas que subsidiam a pesquisa poderem ser agrupadas em "como" e "por que": "como o MP atuou no licenciamento ambiental" e "por que atuou desse modo"; (ii) inexistência de controle por parte do pesquisador sobre os acontecimentos que serão examinados; (iii) o fato de tratar-se de pesquisa voltada para um fenômeno contemporâneo; e (iv) a existência de uma variedade de evidências (documentos, levantamento de dados e entrevistas) para embasar a realização da pesquisa.

A parte teórica do trabalho foi fundamentada em pesquisa bibliográfica sobre os tópicos contemplados na pesquisa realizada, referenciada no levantamento legislativo, bem como na obtenção de dados na ANEEL e na Secretaria de Saneamento e Energia do Estado de São Paulo, além da pesquisa nas bases de dados da SMA e do CAO-UMA.

Dessa abordagem teórica mais genérica, passou-se para uma avaliação mais específica. Assim, verificou-se o processo de licenciamento ambiental conduzido pela SMA, com levantamento de evidências coletadas em documentos e em registro de arquivos existentes naquele órgão de gestão ambiental a respeito de projetos de geração de energia elétrica.

No tocante ao MP, analisou-se a estrutura organizacional do MPE-SP, suas diretivas institucionais de atuação, por meio do levantamento e da leitura crítica de resoluções e casos de jurisprudência do Conselho Superior do Ministério Público do Estado de São Paulo, entrevistas, além de referências coletadas no CAO-UMA. 
Buscando avaliar a atuação prática do MPE-SP no licenciamento ambiental, foi identificado um caso concreto para ser analisado em profundidade, no qual foram identificadas intervenções relevantes daquela instituição (tanto na esfera administrativa quanto na judicial).

Para tanto, debruçamo-nos sobre os autos do processo de licenciamento ambiental e das ações judiciais relacionadas ao projeto estudado para analisar a atuação do MPE-SP, passando daí a avaliar os reflexos de sua intervenção.

Foram também realizadas entrevistas com representantes de órgãos ambientais, da Procuradoria Geral do Estado $^{26}$ e do MPE-SP a respeito das motivações e diretrizes de funcionamento da entidade de que cada qual faz parte e da relação entre esses órgãos: o ministerial e o administrativo.

Foram identificados também atores que tiveram participação no processo de licenciamento ambiental do caso prático escolhido com a finalidade de complementar a pesquisa com informações ausentes dos documentos juntados aos autos oficiais, bem como para ilustrar a descrição com suas impressões em relação aos fatos por eles vivenciados.

Novamente, diante de eventual argumentação de que o trabalho deixa de contemplar a atuação global do MP por se restringir ao Estado de São Paulo, ressalta-se que é da natureza da metodologia adotada investigar isoladamente as evidências recolhidas em uma única fonte, tendo por objetivo analisar em profundidade o seu conteúdo, permitindo que se reconheçam semelhanças e diferenças com relação a outros casos.

\footnotetext{
${ }^{26}$ Conforme analisado no item 6.1, a SMA é representada em juízo pela Procuradoria do Patrimônio Imobiliário, que faz parte da Procuradoria Geral do Estado.
} 
Conforme Yin (2005), essa generalização analítica consiste na lógica da replicação, pela qual, a partir de um conjunto particular de resultados, o pesquisador pode gerar proposições teóricas que seriam aplicáveis a outros contextos. Para tal fim, o caso deve ser selecionado de acordo com uma das seguintes previsões: ou se espera encontrar resultados semelhantes nas diversas unidades investigadas (replicação propriamente dita) ou se espera resultados diferentes em razão de fatores previamente antecipados pelo pesquisador (replicação teórica).

Desta forma, esse autor rebate a críticas de que estudos de caso oferecem pouca base para generalização, o que considera um dos preconceitos que cercam essa estratégia de pesquisa.

\subsection{O ENFOQUE INTERDISCIPLINAR}

A pesquisa ora desenvolvida segue os princípios da ciência ambiental, amparando-se, dessa forma, no estudo interdisciplinar, ou seja, na integração de dois ou mais componentes curriculares na construção do conhecimento visando a uma reconciliação epistemológica, que permita chegar a respostas a questões que uma única disciplina seria incapaz de responder.

O conceito de interdisciplinaridade na ciência ambiental foi defendido por Latour (1994), que criticou a dicotomia "moderna" no sentido de separar o mundo natural do mundo social pois, a partir dessa distinção, poderiam advir resultados negativos. Entre estes, tem-se a impossibilidade de pensar de forma crítica sobre como as condições naturais refletem sobre o homem inserido na cultura e vice-versa. 
Também defensor da interdisciplinaridade da ciência ambiental, Leff (2000) entende que ela implica um processo de inter-relação de processos, conhecimentos e práticas que transborda e transcende o campo da pesquisa e do ensino no que se refere estritamente às disciplinas científicas e a suas possíveis articulações.

Esse autor defende a interdisciplinaridade fundada em um saber ambiental, construída a partir de uma visão daquilo que se deseja alcançar e do objeto de estudo, sem perder de vista as bases teóricas e epistemológicas que estabelecem as condições para a articulação de saberes.

Posteriormente ele adotou o conceito de uma racionalidade socioambiental, a partir da qual se obteriam bases para construir um novo paradigma ${ }^{27}$, com novos valores e propostas de gestão em resposta à crise decorrente da degradação ambiental (2001b).

A idéia de interdisciplinaridade por meio do diálogo retroalimentativo entre as diversas disciplinas pode ser identificada nas idéias de Morin (2002), que a considera parte do desafio contemporâneo da complexidade: a organização e a síntese de conhecimentos de forma a promover esse diálogo, sendo de seu entendimento que os cortes entre as disciplinas destroem as articulações entre categorias cognitivas.

\footnotetext{
27 O conceito de paradigma foi introduzido por Kuhn (1979) que, em seu sentido lato, é o conjunto de valores e crenças que norteia o saber científico de um determinado praticante científico. Para Kuhn, a ciência se desenvolve na medida em que vão ocorrendo rupturas de paradigmas. Nesse aspecto alinhou-se Feyerabend (1979), que afirmou que a finalidade da ciência seria a mudança de paradigma, com a introdução e a expressão de teorias alternativas, e contrapôs-se a Popper (Magee, 1979), que havia proposto o conceito cumulativo da ciência, pelo qual cada teoria nova aperfeiçoaria a anterior, refutando-a, permeado por uma profunda preocupação com a demarcação da ciência, considerando-a um processo racional, sem variáveis subjetivas, baseada em conceitos (teoria) que não historicistas. Popper distinguiu ainda lei social e lei natural, sendo esta referida como a que descreve o que ocorre, enquanto aquela prescreve o que pode e o que não pode ser feito. Sobre o conceito propriamente dito, Masterman (1979) identificou vinte e um sentidos para o termo "paradigma" utilizado por Kuhn, agrupados em três grupos principais: (i) paradigmas metafísicos ou metaparadigmas; (ii) paradigmas sociológicos e (iii) paradigmas de artefato ou paradigmas de construção.
} 
Para Jollivet e Pavé (2002), a pesquisa ambiental é por natureza interdisciplinar e praticamente todas as disciplinas e especialidades são chamadas a oferecer sua contribuição num campo comum de pesquisa.

Não obstante, merece ser ressaltado que, na pesquisa interdisciplinar, é natural que uma ciência seja predominante em relação às demais: aquela que o pesquisador tem como formação de origem e com a qual tenha maior afinidade para o desenvolvimento dos trabalhos e para a avaliação dos resultados. O que não descaracteriza a interdisciplinaridade, uma vez que haja diálogo entre as ciências envolvidas na pesquisa proposta.

Tal qual preleciona Coimbra (2000, p. 58),

(...) O interdisciplinar consiste num tema, objeto ou abordagem em que duas ou mais disciplinas intencionalmente estabelecem nexos e vínculos entre si para alcançar um conhecimento mais abrangente, ao mesmo tempo diversificado e unificado.

(...) Cada disciplina, ciência ou técnica mantém a sua própria identidade, conserva sua metodologia e observa os limites dos seus respectivos campos. É essencial na interdisciplinaridade que a ciência e o cientista continuem a ser o que são, porém intercambiando hipóteses, elaborações.

No presente trabalho, a área de formação de origem da pesquisadora - o Direito - serve como ponto de partida e linha mestra de desenvolvimento. Porém, o tema e os objetivos que se pretende atingir exigem a contribuição de outras áreas de conhecimento para avaliar a questão além da fundamentação jurídica. 


\subsection{RELEVÂNCIA DO TEMA}

Este trabalho foi motivado pela constatação empírica da representativa atuação do MP em questões que envolvem a Administração Pública na gestão do meio ambiente.

O banco de dados do CAO-UMA demonstra um aumento crescente e significativo no número de ações civis públicas propostas e de inquéritos civis instaurados pelas Promotorias de Justiça de Meio Ambiente existentes na Capital e nas Comarcas do Estado ${ }^{28}$.

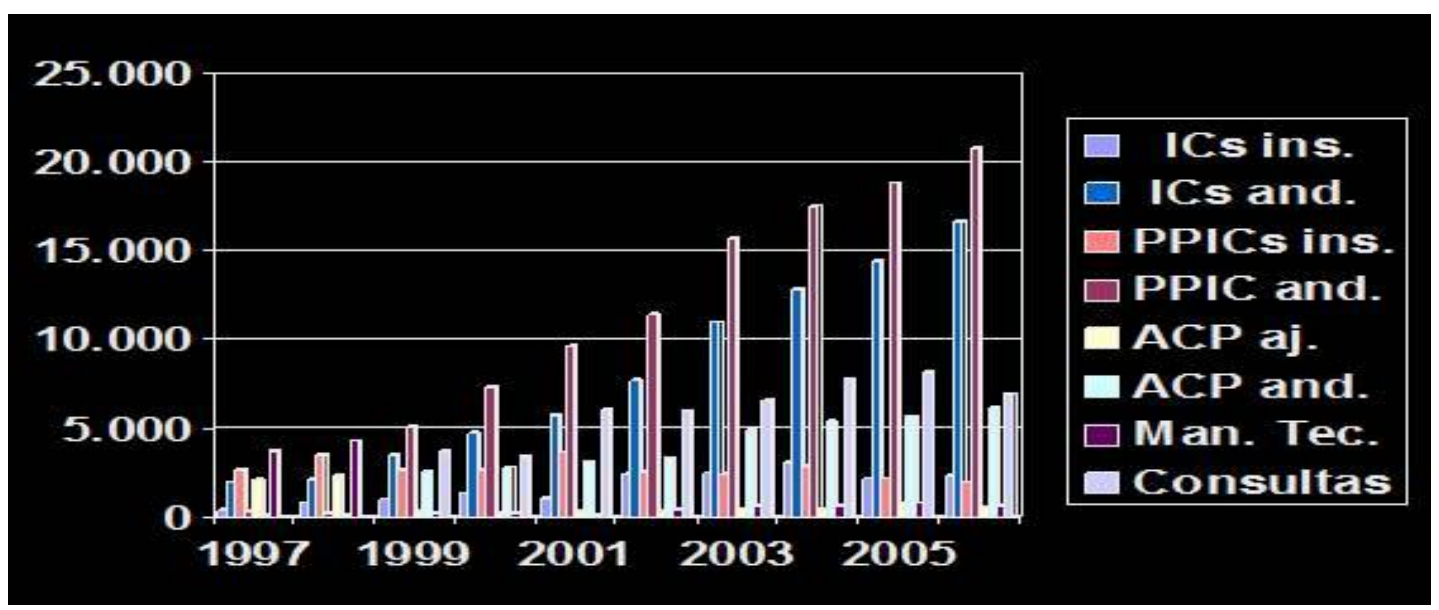

Figura 2 - Dados da atuação do Ministério Público do Estado de São Paulo na tutela do meio ambiente de 1997 a 2006 (fonte: CAO-UMA, 2007). Sendo: ICs ins. (inquéritos civis instaurados); ICs and. (inquéritos civis em andamento); PPICs ins.: procedimentos preparatórios para inquéritos civis instaurados; PPICs and. (procedimentos preparatórios para inquéritos civis em andamento); ACP aj. (ações civis públicas ajuizadas); ACP and. (ações civis públicas em andamento); Man. Tec. (manifestações técnicas).

Macedo Junior (1999a) assinala que o MP tornou-se um novo e importante ator político no cenário brasileiro, sendo sua atuação notória, reconhecida pelos mais diferentes meios, inclusive na mídia, que cotidianamente veicula notícias sobre seus feitos.

\footnotetext{
${ }^{28}$ Os dados quantitativos constam do Anexo 1. Ressalvamos que esses dados serão meramente referenciados, por contemplarem a atuação das Promotorias de Meio Ambiente de forma genérica, sem distinguir o objeto da atuação nem seus resultados; isso fez com que se mostrasse inviável individualizar a atuação do MPE-SP sobre os processos de licenciamento ambiental em relação aos demais assuntos relacionados à proteção ambiental.
} 
Com base na legitimidade constitucional conferida pela CF-88 e nos instrumentos de que dispõe, o MP passou a acompanhar processos de licenciamento ambiental com a justificativa de zelar pelo pleno atendimento às normais ambientais por parte dos órgãos licenciadores e, dessa forma, prevenir danos ambientais futuros que poderiam advir da implantação e da operação de empreendimentos que fossem licenciados irregularmente.

Ocorre que, se por um lado, a instituição incentiva o acompanhamento dos processos de licenciamento ambiental com o fim de prevenir danos ambientais que poderiam decorrer no caso de uma atuação $a$ posteriori ${ }^{29}$, por outro lado, essa atuação pode gerar novos conflitos, face à legitimidade da Administração Pública para conduzir o licenciamento ambiental.

Embora seja farta a bibliografia produzida a respeito de diversos aspectos do MP, tais como a sua atuação na proteção de direitos difusos e coletivos (incluindo-se sua atuação na tutela ao meio ambiente ecologicamente equilibrado), o mesmo não se pode dizer sobre a sua atuação no exercício de zelar pelo respeito dos Poderes Públicos e dos serviços de relevância pública aos direitos constitucionalmente assegurados.

Menos estudada ainda é a relação entre essa atribuição e a fiscalização dos órgãos da Administração Pública legitimados para proteger o meio ambiente.

O foco temático nos empreendimentos de geração de energia deve-se à relevância e à atualidade dessa questão.

\footnotetext{
${ }^{29}$ Conforme orientações constantes do Roteiro para atuação do Ministério Público Federal em licenciamentos ambientais da Procuradoria Geral da República (2005).
} 
Ao longo das últimas duas décadas, o consumo de energia elétrica apresentou índices de expansão bem superiores ao Produto Interno Bruto. O Plano Nacional de Energia 2030 (MME, 2006) prevê que, em mais duas décadas, o consumo de energia elétrica será ainda maior, podendo triplicar em relação aos níveis atuais.

Tendo em mente a dimensão dessa projeção, o Plano Decenal de Expansão de Energia Elétrica 2006-2015 (MME, 2006) prevê a necessidade de aumento na capacidade de geração elétrica da ordem de R $\$ 75$ bilhões até 2015 .

Para se atingir esse valor, o Plano aponta a necessidade de intervenção em áreas de grandes restrições ambientais e a utilização de matrizes energéticas controversas como alternativas inevitáveis para acompanhar o crescimento estimado da demanda.

A atuação do MP na solução (ou não) de conflitos passados por si justificaria um estudo, o que é reforçado pela perspectiva de conflitos futuros. 


\section{CONTEXTUALIZAÇÃO}

\subsection{CONFLITOS AMBIENTAIS E O DIREITO}

O licenciamento ambiental é um instrumento preventivo conduzido pela Administração Pública para conciliar interesses conflitantes envolvendo a proteção ambiental e os interesses que envolvem impactos ao meio ambiente e/ou a utilização de recursos naturais.

Ao mesmo tempo, a atuação do órgão administrativo legitimado para essa função é sujeita à fiscalização pelo MP, que também tem o papel de intermediador de conflitos. Daí este capítulo se deter ao estudo desse tópico.

Em escala global, a Revolução Industrial é apontada por muitos autores como marco para o surgimento dos conflitos ambientais ${ }^{30}$. Com o incremento na produção de bens e, também, no seu consumo, houve aumento na apropriação de recursos naturais disponíveis e no nível de poluição em diversas escalas. Sendo que, conforme destacado por Vieira e Weber (2002), os recursos disponíveis para o atendimento dessas necessidades são limitados, finitos e escassos.

${ }^{30}$ Nesse sentido, Nusdeo (1975), Leff (2001), Goldemberg e Villanueva (2003), Agra Filho (2008), entre outros. 
Ribeiro (2005) leciona que, desde 1972, ocasião da Conferência sobre o Meio Ambiente Humano da Organização das Nações Unidas, em Estocolmo / Suécia, assim como nas diversas conferências internacionais que a sucederam, passou-se a discutir, em escala global, a preocupação pela insuficiência dos recursos naturais do planeta caso fosse mantido o padrão de vida vigente, especialmente o de alguns países, como os Estados Unidos.

Porém, ao longo dessas discussões internacionais, verificou-se que o esquema de consumo e produção não viáveis haviam se reforçado, assim como as desigualdades sociais, tanto na relação entre os países quanto dentro dos próprios países. E, para ilustrar esses fatos, aquele autor aponta que os 30 países mais desenvolvidos representavam $20 \%$ da população mundial, mas produziam e consumiam $80 \%$ da energia não renovável.

Portanto, o conflito ambiental surge com a contraposição da apropriação de recursos naturais limitados com a capacidade de suporte do meio. Fenômenos que, para Nusdeo (2005), deverão se agravar na medida em que as necessidades humanas dentro da sociedade moderna tendem a se multiplicar indefinidamente ou infinitamente.

Martinez Alier (2007, p. 352) acentua essa tendência, alertando que:

impulsionada pelo consumo, a utilização de energia e de materiais pela economia global é mais alta do que nunca. Paradoxalmente, os ganhos auferidos pela ecoeficiência podem reforçar uma ampliação da demanda energética e do consumo de materiais em razão do próprio barateamento dos seus custos.

Seguindo esse raciocínio, pode-se prever que os conflitos ambientais estão longe de ser resolvidos e, ainda, tendem a se acirrar. 
Leff (2001b) entende que os conflitos ambientais implicam visões e interesses diferenciados, nos quais se inscrevem diferentes formas e estratégias de poder no saber. Como caminho para a sua compreensão e solução, o autor indica a necessidade de um diálogo de saberes, com a abertura do cerco das ciências: daí, novamente, fica realçada a importância da interdisciplinaridade no desenvolvimento da ciência ambiental.

Em outra obra, Leff (2001a) destaca o surgimento de novos atores: o Estado no novo papel de responsável pelo planejamento e ordenamento ecológico, novas organizações profissionais, novos órgãos não governamentais, grupos privados e associações civis, novas redes de relações políticas, sociais e econômicas e cidadãos organizados.

No Brasil, o MP é um dos atores que ganharam destaque com relação à proteção do meio ambiente, inclusive por meio do controle dos órgãos administrativos, tendo-lhe sido conferidas atribuições e instrumentos que permitem a ele atuar no papel de mediador de conflitos ambientais, como alternativa ao Judiciário.

Com as mudanças que foram havendo na conscientização sobre a problemática ambiental, com os novos movimentos sociais que começaram a ganhar força, foi-se também discutindo novas estratégias para lidar com os conflitos ambientais.

Vieira e Weber (2002) observam que as evidências empíricas já acumuladas sobre os impactos ecológicos das ações humanas questionaram as formas usuais de gestão das relações sociedade-natureza, fazendo com que uma preocupação mais pragmática passasse a dominar, privilegiando a explicitação e a avaliação crítica das pré-condições de viabilidade para uma gestão integrada e antecipativo-preventiva dos problemas ambientais. 
Dentro do conceito antecipativo-preventivo dos problemas ambientais, destaca-se, no ordenamento nacional, o licenciamento ambiental, previsto pela Política Nacional do Meio Ambiente brasileira como um dos instrumentos existentes para a prevenção e/ou a mitigação de danos ambientais. E que por si tende a ser conflituosa, ao abarcar interesses conflitantes envolvidos na implantação de um novo empreendimento em determinada localidade.

A solução para os conflitos ambientais foi considerada complexa por Fink e Souza (2002), pois envolve múltiplos interesses e a negociação não tem como objeto o meio ambiente, mas a adoção de medidas destinadas à sua recuperação e à forma de adoção dessas medidas.

Existindo conflitos, surge a tutela governamental e o Direito. Conforme Derani (2008, p. 65):

(...) as normas de proteção ao meio ambiente partem do conflito de interesses para poder estabelecer uma adequação dos interesses de poluidores e dos atingidos pela poluição ambiental, visando alcançar, dentro das atividades humanas, um equilíbrio ambiental.

(...) a legislação ambiental confronta-se basicamente com uma dupla tarefa: por um lado ela deve apresentar um arcabouço legislativo para uma luta eficiente contra a imensa variedade de problemas ambientais (viabilização da proteção ambiental). Por outro lado, ela precisa também trabalhar com uma coordenação entre interesses concorrentes e conflitantes, inclusive reescrevendo os conceitos que se encontram nos mais diversos ramos do direito.

Essa Autora (2008, p. 12) alerta que

(...) o direito, porém, contém a lei, uma vez que ele é formado de outros elementos, e só se manifesta quando assentado neste conjunto de lei e fato interligados pela ação.

(...) A má compreensão da norma jurídica e sua redução a mero conceito lógico-hipotético, ou unicamente a um texto imperativo, levantam de forma aguda a questão sobre o modo apropriado da relação entre direito e realidade, exatamente no que diz respeito ao momento da concretização do direito. 
Antes de analisar com mais vagar o papel do MP na fiscalização da atuação do Poder Público na proteção do meio ambiente, segue um breve panorama sobre a proteção ambiental nos outros países e um estudo sobre o licenciamento ambiental e o EIA para, então, avaliar um novo conflito: a decorrente do controle do MP sobre os trabalhos dos órgãos ambientais.

\subsection{PROTEÇÃO AMBIENTAL EM OUTROS PAÍSES}

No Brasil, a CF-88, ao mesmo tempo em que garante o direito de todos ao meio ambiente ecologicamente equilibrado, conferiu ao Poder Público e à coletividade o dever de protegê-lo para as presentes e para as futuras gerações ${ }^{31}$.

Para tal fim, a coletividade tem a possibilidade de ser parte ativa na proteção ambiental, utilizando-se da ação popular, existente desde a década de 1960, para situações condicionadas pela lei, mas que apresenta limitada repercussão por, entre outros fatores, atingir somente o Poder Público $^{32}$. Ou representar ao MP ou aos órgão de proteção de meio ambiente.

Em relação aos órgãos oficiais, a legislação brasileira atribuiu competências aos órgãos administrativos relacionados na Política Nacional do Meio Ambiente ${ }^{33}$ e ao MP.

\footnotetext{
${ }^{31}$ CF-88, artigo 225, caput (BRASIL, 1988)

${ }^{32}$ Conforme destacado por Grinover (1999, p. 96), "a ação popular não tinha condições de cobrir o amplo espectro da tutela dos interesses difusos, nem mesmo pelo que respeitava ao meio ambiente, uma vez que seu exercício ainda permanece subordinado a uma ilegalidade proveniente da conduta comissiva ou omissiva do Poder Público, enquanto a ameaça ou violação dos interesses difusos freqüentemente provém de ações privadas."

${ }^{33}$ A Política Nacional do Meio Ambiente foi instituída pela Lei Federal 6.938/81, cujo artigo $6^{\circ}$ relaciona os órgãos do Sistema Nacional do Meio Ambiente: "órgãos e entidades da União, dos Estados, do Distrito Federal, dos Territórios e dos Municípios, bem como as fundações instituídas pelo Poder Público” (BRASIL, 1981).
} 
Ao órgão de gestão ambiental, cabe realizar o licenciamento ambiental, bem como fiscalizar e elaborar normas regulamentadoras internas para sua própria organização e exercício, enquanto ao MP cabe a função jurisdicional de tutelar o meio ambiente nas esferas civil e penal e, ainda, a competência para zelar e fiscalizar a atuação administrativa do Poder Público no exercício das funções públicas visando aos interesses garantidos constitucionalmente ${ }^{34}$.

Por conta dessas atribuições ${ }^{35}$ e dos instrumentos de que dispõe, o MP brasileiro tem a possibilidade de participar de instâncias administrativas do licenciamento ambiental, podendo ou não dispor da via judicial para o desempenho das funções inovadoras que the foram conferidas principalmente com a CF-88. Esse é um diferencial dessa instituição.

Portanto, a legislação pátria concedeu aos órgãos ambientais, ao MP e à coletividade meios para atuar diretamente na proteção do meio ambiente. Para efeito de contextualização, será apresentada, a seguir, a proteção ambiental em alguns outros países, bem como as atribuições das instituições equivalentes ao MP brasileiro no Direito Comparado.

\footnotetext{
${ }^{34}$ Não somente o já mencionado artigo 225 da CF-88, que prevê a obrigação ao Poder Público de proteger o meio ambiente ecologicamente equilibrado, como também os dispositivos que tratam dos instrumentos e atribuições do MP incluem sob sua tutela as questões ambientais, especialmente dos artigos 127 a 130 (BRASIL, 1988). O mesmo o fez a Política Nacional do Meio Ambiente instituída pela Lei Federal 6.938/81 (BRASIL, 1981) e a Lei da Ação Civil Pública - Lei Federal 7.347/95 (BRASIL, 1995).

35 A CF-88 prevê, em seu artigo 129, as funções institucionais do Ministério Público: "I - promover, privativamente, a ação penal pública, na forma da lei; II - zelar pelo efetivo respeito dos Poderes Públicos e dos serviços de relevância pública aos direitos assegurados nesta Constituição, promovendo as medidas necessárias a sua garantia; III - promover o inquérito civil e a ação civil pública, para a proteção do patrimônio público e social, do meio ambiente e de outros interesses difusos e coletivos; IV - promover a ação de inconstitucionalidade ou representação para fins de intervenção da União e dos Estados, nos casos previstos nesta Constituição; V - defender judicialmente os direitos e interesses das populações indígenas; VI - expedir notificações nos procedimentos administrativos de sua competência, requisitando informações e documentos para instruí-los, na forma da lei complementar respectiva; VII - exercer o controle externo da atividade policial, na forma da lei complementar mencionada no artigo anterior; VIII - requisitar diligências investigatórias e a instauração de inquérito policial, indicados os fundamentos jurídicos de suas manifestações processuais; IX exercer outras funções que lhe forem conferidas, desde que compatíveis com sua finalidade, sendo-lhe vedada a representação judicial e a consultoria jurídica de entidades públicas” (BRASIL, 1988).
} 
Conforme levantamento feito por Paes (2003), ao contrário do MP brasileiro que é independente dos três Poderes do Estado, os órgãos assemelhados nos outros países estão associados ao Poder Executivo (caso da França, da Alemanha, da Espanha, da Inglaterra e dos Estados Unidos da América), ao Poder Judiciário (Itália e Portugal) ou ainda ao Poder Legislativo (avaliado por aquele autor na época da ex-União Soviética).

Esse autor avalia ainda que, nos Estados Unidos da América, a instituição similar ao MP brasileiro - Public Prosecutor, General Attorney ou District Attorney - desempenha funções mais persecutórias; essa instituição americana não se destaca nas questões ambientais. Quanto ao ingresso dos membros na carreira, o sistema é eletivo ${ }^{36}$, diferentemente do Brasil, onde o processo seletivo consiste em concurso público.

A proteção do meio ambiente (e dos interesses supra-individuais de modo geral) faz-se por meio de class actions e de public interest actions: estas compreendem um grupo de mecanismos judiciais de prestação coletiva que buscam, via de regra, reprimir o uso ilegal ou inconstitucional do poder por parte de um ramo da Administração, enquanto aquelas consistem em demandas coletivas propostas por uma ou mais pessoas que iniciam e mantêm uma ação em nome de um grupo de pessoas ou de uma classe, para obter a solução de um conflito coletivo de interesse público (BENJAMIN, 1991).

Jukovski (1997) analisa que na Argentina, à semelhança do Brasil, foi atribuído a todos o dever de preservar o ambiente saudável, equilibrado, apto ao desenvolvimento humano, bem como o de recompô-lo em caso de dano.

\footnotetext{
${ }^{36}$ Paes (2003) critica o sistema americano de ingresso na carreira por entender que ele propicia a busca de votos exibindo número de condenações obtidas ou crimes esclarecidos, ou seja, que a referência se faça pela lógica de produtividade mais do que na lógica de justiça.
} 
Têm legitimidade para agir judicialmente na hipótese de dano ambiental, a vítima (pela chamada Acción Popular), o Estado pelo Defensor do Povo e as associações de proteção do ecossistema, preenchidos os requisitos legais.

Na Itália, Jukovski (1997) comenta que o Estado e as entidades territoriais possuem legitimidade para promover medidas judiciais em face de danos ambientais. As associações podem participar do processo como litisconsortes àqueles, desde que haja interesse legítimo.

Já na França, essa autora verificou que as controvérsias relacionadas ao meio ambiente são dirimidas, geralmente, no âmbito da jurisdição administrativa, sendo remetidas à via judicial as demandas nas quais não se verifiquem interesses de entidades públicas. O MP, embora dotado de princípios como autonomia e alguns privilégios, é vinculado ao Poder Executivo, estando sujeito à supervisão do Ministro da Justiça, bem como a sanções como remoção, rebaixamento e exoneração (PAES, 2003).

$\mathrm{Na}$ Inglaterra, há ações judiciais diversas para tratar de interesses difusos, tais como representatives actions, test actions e relator actions. Há uma instituição denominada Crown Prosecution Service, que revê as evidências e decide se os processos devem ou não prosperar. Suas atribuições estão ligadas estritamente à Polícia, portanto persecutórias, não contemplando as atribuições que cabem ao MP brasileiro (DAVID, 1993).

O modelo holandês é elogiado por Antunes (2008), por ter órgãos administrativos distintos para a condução do licenciamento ambiental: uma agência é encarregada de analisar os estudos de impacto ambiental e sobre eles emitir parecer, enquanto uma outra é responsável pelo licenciamento ambiental propriamente dito. 
O fundamento para esta distinção é permitir que a agência mais técnica a cargo da avaliação dos estudos seja independente, não estando sujeita às pressões típicas do licenciamento ambiental. Desta forma, dentro da esfera administrativa, a existência de duas agências permitiria que haja controle do licenciamento ambiental de uma agência pela outra.

Em Portugal, o Estado tem a incumbência de cuidar do meio ambiente, por meio de organismos próprios, sendo também previsto o envolvimento e a participação dos cidadãos, para permitir que seja garantido o direito de todos a um ambiente de vida humano, sadio e ecologicamente equilibrado (JUKOVSKY, 1997).

O MP português goza de autonomia, mas esta é limitada, na medida em que na área cível ainda vigora a atribuição de representar o Estado. Isso permite a ingerência do Executivo na instituição, já que cabe ao Ministro da Justiça emitir diretivas sobre a atuação do MP nas causas cíveis em que há interesse do Estado (JATAHY, 2007).

Em síntese, Macedo Junior (1999b) conclui que o alto grau de autonomia do MP perante os demais poderes, sua independência, sua atuação na tutela dos interesses difusos e coletivos, com inevitável repercussão na gestão das políticas públicas, tornam aquela instituição sui generis em relação aos seus similares em outros países.

Daí porque esse autor assinala que essas características fazem do MP uma importante inovação política e institucional no Brasil. 
$\mathrm{Na}$ mesma linha, Gavronski (2005) destaca que as atribuições e prerrogativas do MP brasileiro não têm similares no sistema político de outros Estados ocidentais, já que não há nos outros países as atribuições tão claramente determinadas ao MP no sentido de tutelar o meio ambiente e permitir-lhe a fiscalização de órgãos de licenciamento ambiental, de forma independente e sem a ingerência de outros órgãos e Poderes.

\subsection{POLÍTICAS DE ENERGIA E OS CONFLITOS AMBIENTAIS}

Em seu estudo, Odum (1997) fez uma analogia entre as cadeias ecológicas e as relações sociais, a partir do que constatou que a energia é parte essencial do sistema de todos os seres vivos e, também, para as sociedades humanas.

Sendo a energia a base para a avaliação do desenvolvimento e da decadência dos povos, esse autor concluiu pela urgência de uma mudança de padrão de consumo de todos os bens incluindo, mas não se limitando à energia - para evitar a decadência das comunidades, assim como ocorre com os elementos de uma cadeia ecológica, pelo ritmo acelerado de apropriação dos recursos naturais incompatível com a capacidade de suporte do meio.

Conforme já mencionado neste trabalho, a Revolução Industrial é apontada por muitos autores como marco para o surgimento dos conflitos ambientais ${ }^{37}$. Também foi um marco inicial para o crescente aumento do consumo de energia, em escala global ${ }^{38}$.

\footnotetext{
37 Conforme referido no item 2.1.

${ }^{38}$ Nesse sentido, Goldemberg e Villanueva (2003).
} 
Conforme analisam Goldemberg e Villanueva (2003), se originalmente esse consumo foi concentrado na produção industrial, atualmente está presente no trabalho, no lazer, nas tarefas domésticas, no transporte e na prática de esportes, em níveis cada vez maiores. Desta forma, não se prevê perspectivas de reversão nessa tendência crescente de demanda.

Esses autores postulam a relação entre o consumo de energia e taxas utilizadas na valoração do índice de desenvolvimento humano: na maioria dos países em desenvolvimento, onde o consumo de energia comercial per capita é inferior a uma tonelada equivalente de petróleo por ano, as taxas de analfabetismo, mortalidade infantil e fertilidade são mais altas e a expectativa de vida mais baixa do que naqueles onde esse consumo aumenta para valores acima de duas ou mais tonelada equivalente de petróleo por ano.

Nessa linha, Veiga (2006) alerta que a carência de energia elétrica pode comprometer o desenvolvimento e assim acabar comprometendo as condições futuras de coercibilidade da proteção ambiental, na medida em que a falta de recursos restringe iniciativas de educação ambiental e o próprio Estado vai se desaparelhando de instrumentos de exeqüibilidade.

Desde meados dos anos 1990, a insuficiência de investimentos e de planejamento no setor elétrico, agravada pelas condições meteorológicas desfavoráveis consistentes em um longo período de poucas e insuficientes precipitações atmosféricas, culminou em uma crise energética pelo déficit entre geração e consumo de energia, que levou por sua vez ao maior racionamento de energia elétrica da história do País, entre junho de 2001 e fevereiro de 2002. 
Ao mesmo tempo, foram propostas políticas e programas voltados para o estímulo a empreendimentos de geração de energia, cujas matrizes fossem diversas à da hidrelétrica, cuja instalação e entrada em operação são demoradas e, naquela ocasião, revelaram sua instabilidade face à sua dependência às condições meteorológicas.

Dentre os programas governamentais de incentivo, destacou-se o $\mathrm{PPT}^{39}$, que previa o aumento da oferta de energia em cerca de 13 mil MW até 2003 com a implantação de 49 termelétricas em 18 estados. Oferecendo projetos que pudessem ser implantados de forma mais rápida do que as hidrelétricas, por meio desse programa buscou-se captar investimentos a curto prazo em empreendimentos que permitissem garantir o nível de confiabilidade nas horas de pico e em situações com maiores riscos de déficit (COELHO; PALETTA; FREITAS, 2001).

Havia também uma disponibilidade abundante de gás natural em função do contrato assinado pelo Brasil com a Bolívia, na base de take or pay ${ }^{40}$.

Nesse sentido, a implantação de novas termelétricas movidas a gás natural permitiria conciliar a compulsória utilização do gás importado com o aumento no potencial de fornecimento de energia elétrica a partir daquela matriz energética.

\footnotetext{
${ }^{39}$ O PPT foi instituído pelo Decreto Federal 3.371, de 24.02.2000, que conferiu algumas prerrogativas às usinas termelétricas integrantes daquele Programa: garantia de suprimento de gás natural pelo prazo de até 20 anos; garantia da aplicação do valor normativo à distribuidora de energia elétrica por um período de até 20 anos; e garantia pelo Banco Nacional de Desenvolvimento Econômico e Social de acesso ao Programa de Apoio Financeiro a Investimentos Prioritários no Setor Elétrico (BRASIL, 2000).

${ }^{40}$ Conforme Passos (1988), pelo contrato de compra e venda entre e Petrobras S.A. e a Yacimientos Petroliferos Fiscales Bolivianos, assinado em agosto de 1996, esta empresa boliviana se comprometeu a vender e aquela empresa brasileira a comprar, em regime de take or pay (pagamento compulsório mesmo com a utilização abaixo do valor contratado), quantidades crescentes de gás, que seria iniciado com 8 milhões de $\mathrm{m}^{3} / \mathrm{dia}$, atingindo 16 milhões de $\mathrm{m}^{3} / \mathrm{dia}$, no oitavo ano e permanecendo nesse patamar até o vigésimo ano. Ainda no mesmo contrato, a Yacimientos Petroliferos Fiscales Bolivianos concedeu à Petrobras Ltda. uma opção de compra, com preferência sobre terceiros, de quantidades adicionais de gás, provenientes ou não de novas descobertas bolivianas até o limite de 30 milhões de $\mathrm{m}^{3} / \mathrm{dia}$, desde que tais quantidades estejam disponíveis e não sejam necessárias para atender à demanda do mercado doméstico da Bolívia. Em 01.05.2006, esse acordo comercial foi afetado pela determinação do Governo boliviano de que todas as empresas petrolíferas estrangeiras que operavam naquele país deveriam passar seu controle acionário para a empresa estatal boliviana.
} 
Como parte das ações para implementar esse programa, foi editada a Medida Provisória 2.147/01 $1^{41}$, que estabeleceu diretrizes para programas de enfrentamento da crise de energia elétrica, entre as quais, a celeridade na análise e na emissão de licenças ambientais para empreendimentos de geração e transmissão de energia que fossem considerados prioritários.

Tais medidas acabaram por acirrar conflitos entre a pressão para a solução imediata da crise de energia elétrica e as preocupações quanto à proteção do meio ambiente que, na prática, resultaram em questionamentos judiciais e extrajudiciais que suspenderam o curso do licenciamento ambiental de muitos desses projetos.

No final, o PPT acabou não vingando, não somente por resistências no licenciamento ambiental, mas por fatos posteriores que desmotivaram o interesse comercial no segmento de geração de energia termelétrica: a redução representativa do consumo durante o período do racionamento, aliada às chuvas, permitiram que os reservatórios das usinas hidrelétricas voltassem a níveis suficientes para suprir a demanda energética da época.

Assim, em fevereiro de 2002, o balanço energético se re-equilibrou e o racionamento foi encerrado. Porém, passados mais de sete anos do encerramento do último racionamento de energia elétrica, ainda existe o receio de que novo déficit energético volte a ocorrer.

\footnotetext{
${ }^{41}$ Inicialmente foi editada a Medida Provisória 2.147/01, revogada e reeditada, sucessivamente, pelas Medidas Provisórias 2.148/01, 2.152/01 e 2.198/01, cada qual com suas reedições, até a entrada em vigor da Emenda Constitucional 32/01 que, entre outras medidas, determinou que as medidas provisórias deveriam ser convertidas em lei no prazo máximo de 120 dias, ou se não as relações jurídicas constituídas e decorrentes de atos praticados durante sua vigência conservar-se-iam tal qual foram regidas na sua última versão. Neste caso, ficaram convalidou os efeitos da Medida Provisória 2.128-4/01.
} 
Bardelin (2004) defende que a crise de 2001 não foi a primeira e, possivelmente, não será a última, devido à utilização cada vez maior e mais difundida de aparelhos que necessitam de energia elétrica para funcionar. Ele prevê que, apesar da evolução de equipamentos com maior eficiência energética, a expansão na geração, transmissão e distribuição de energia elétrica não é suficiente para acompanhar o ritmo de crescimento da demanda, que foi interrompido somente durante o racionamento.

De fato, após o fim da crise energética, velhos hábitos foram sendo retomados e o consumo voltou aos níveis anteriores à da restrição forçada do consumo de energia por conta do racionamento. O que, para Ribeiro (2003), é um exemplo de que não é possível afirmar que as políticas educacionais e a mobilização da comunidade tenham conseguido alterar costumes da população brasileira, apesar dos esforços que vêm sendo envidados.

Assim, a crise energética é de difícil solução, por ser praticamente impossível contar com a solução óbvia (redução do consumo de energia) e as alternativas energéticas (fontes de energia renováveis, eficiência energética, conservação de energia) não terem condições de assumir o papel ora ocupado pelos combustíveis fósseis que representam $80 \%$ do consumo mundial (GOLDEMBERG; VILLANUEVA, 2003).

Atualmente, a necessidade de investimentos em energia é inquestionável. Pelos dados de agosto de 2009, no Brasil são gerados cerca de 99 milhões de kW de energia elétrica; outros 8 milhões de kW são importados de Paraguai, Argentina, Venezuela e Uruguai, totalizando uma oferta de energia disponível superior a 100 milhões de $\mathrm{kWh}$ de energia ${ }^{42}$.

\footnotetext{
${ }^{42}$ Conforme dados da ANEEL (2009).
} 
Pela projeção feita no Plano Nacional de Energia 2030 - "Estratégia para a expansão da oferta" (MME, 2006), o consumo de energia elétrica poderá triplicar até 2030, sendo que até o ano de 2015, o Plano Decenal de Expansão de Energia Elétrica 2006-2015 do MME (2006) prevê a necessidade de expansão do parque gerador nacional entre 3,9\% a 5,5\% ao ano, e investimentos da ordem de $\mathrm{R} \$ 75$ bilhões para a expansão da geração.

Nesse contexto, cabe mencionar que, em maior ou menor grau, a implantação e a operação das diferentes fontes de energia causam impactos ambientais.

Conforme estudado por Inatomi e Udaeta (2005), as hidrelétricas acarretam destruição de fauna e de flora, interferem no fluxo dos rios e produzem gases como o metano pela decomposição da vegetação submersa; a nuclear traz riscos específicos (passivo decorrente do lixo nuclear e riscos de acidentes, entre outros); as turbinas eólicas emitem ruído, podendo interferir em ondas eletromagnéticas, modificar a circulação padrão do ar e afetar a avifauna; os sistemas geradores a partir da energia solar causam impactos durante a fabricação, transporte, instalação, operação, manutenção e descomissionamento.

No caso das termelétricas, Ribeiro (2003) alerta que, por conta da emissão de gases que contribuem para a mudança do clima, o emprego dessa alternativa para suprir a demanda energética pode alterar um quadro favorável ao Brasil no que se refere às emissões atmosféricas, o que, por si, demonstra que essa não é a solução mais indicada.

Restando certo que a capacidade de geração de energia elétrica precisará aumentar, necessariamente haverá impactos ambientais, independentemente da matriz energética adotada e da região, surgindo ou acirrando-se os conflitos ambientais resultantes. 


\section{LICENCIAMENTO AMBIENTAL E ESTUDO DE IMPACTO AMBIENTAL}

\subsection{Previsão Legal do Licenciamento ambiental E do Estudo de impacto} AMBIENTAL

A CF-88 dedicou o Capítulo VI do Título VIII - Da Ordem Social - ao meio ambiente, constituído de um único artigo, no qual se postula que "Todos têm direito ao meio ambiente ecologicamente equilibrado, bem de uso comum do povo e essencial à sadia qualidade de vida, impondo-se ao Poder Público e à coletividade o dever de defendê-lo e preservá-lo para as presentes e futuras gerações"

Não obstante haja um capítulo específico, Derani (2008, p. 18) salienta que "o capítulo de meio ambiente na Constituição Federal não esgota as normas sobre meio ambiente e recursos naturais". De fato, há referências esparsas ao assunto ao longo do texto constitucional, de forma que é da leitura abrangente da CF-88 que se verifica o significado dado por ela ao meio ambiente, bem como os pressupostos para o desenvolvimento sustentável.

Entre as obrigações ao Poder Público para assegurar a efetividade do direito ao meio ambiente ecologicamente equilibrado, a CF-88 inclui a exigência de EIA no licenciamento de empreendimentos expressamente previstos na legislação ${ }^{44}$.

\footnotetext{
${ }^{43}$ CF-88, artigo 225, caput (BRASIL, 1988).

${ }^{44}$ CF-88, artigo 225, $1^{\circ}$, IV: "exigir, na forma da lei, para instalação de obra ou atividade potencialmente causadora de significativa degradação do meio ambiente, estudo prévio de impacto ambiental, a que se dará publicidade" (BRASIL, 1988). Esse assunto havia já sido tratado em 1981, pela Política Nacional do Meio Ambiente instituída pela Lei Federal 6.931/81 (BRASIL, 1981), além das seguintes Resoluções Conama: 001/86 que dispõe genericamente sobre o EIA-RIMA (CONAMA, 1986), à qual se seguiram, regulamentando o EIA em
} 
O EIA é conceituado por Milaré (2009) como um estudo realizado sob a orientação do órgão licenciador que, por meio de instruções técnicas específicas, ou termos de referência, indica a abrangência do estudo e os fatores ambientais a serem considerados detalhadamente.

Também merece ser considerado que o EIA se diferencia dos outros estudos ambientais por ter prevista em norma uma relação de requisitos mínimos a serem contemplados ${ }^{45}$, os quais poderão ser complementados pelo órgão ambiental competente. Além disso, há a previsão obrigatória de audiências públicas sempre que elas sejam solicitadas.

Já o RIMA consiste numa síntese das conclusões obtidas no EIA, sem o grau de complexidade técnica do estudo completo, por ser destinado não ao órgão ambiental, mas para ser utilizado nas discussões populares visando a esclarecer o projeto ${ }^{46}$.

Por isso, a legislação exige que o RIMA seja apresentado de forma objetiva, compreensível, com as informações traduzidas em linguagem acessível, com ilustrações que facilitem a compreensão a respeito das vantagens e das desvantagens do projeto, bem como todas as conseqüências ambientais de sua implementação ${ }^{47}$.

situações específicas, a 006/87 (CONAMA, 1987) que prevê os procedimentos de licenciamento de obras de grande porte relacionados à geração de energia elétrica e a 009/87 (CONAMA, 1987b) que estabelece regras para a realização de audiências públicas. Sendo precedido, sem tantos detalhamentos, na Lei Federal 6.803/80 (CONAMA, 1980) que tratava do zoneamento industrial nas áreas críticas de poluição, inspirado em diretrizes da Agência Ambiental Norte-americana de 1969 e pela Política Nacional de Meio Ambiente.

${ }^{45}$ A Resolução CONAMA 001/86 define os requisitos e diretrizes do EIA-RIMA (CONAMA, 1986), que inclui nos seus artigos $5^{\circ}$ e $6^{\circ}$, entre outros: a análise das alternativas tecnológicas e de localização de projeto, confrontando-as com a hipótese de não execução do projeto; a identificação dos impactos ambientais; a definição das áreas de influência do projeto; a compatibilidade com e programas governamentais; diagnóstico ambiental considerando o meio físico, o meio biológico e os ecossistemas naturais, o meio sócio-econômico, definição das medidas mitigadoras dos impactos negativos; e elaboração do programa de acompanhamento e monitoramento.

${ }^{46}$ A Resolução CONAMA 001/86, em seu artigo 9º , estabelece que o RIMA refletirá as conclusões do estudo de impacto ambiental e o seu conteúdo mínimo (CONAMA, 1986).

${ }^{47}$ Conforme Resolução CONAMA 001/86, artigo 9º parágrafo único (CONAMA, 1986). 
Machado (2008) explica a distinção entre EIA e RIMA da seguinte forma: "o estudo é de maior abrangência que o relatório e o engloba em si mesmo. O EIA compreende o levantamento da literatura científica e legal pertinente, trabalhos de campo, análises de laboratório e a própria redação do relatório".

O EIA-RIMA é exigido quando se tratar de empreendimento considerado de significativo impacto, cuja relação exemplificativa consta da legislação. Nesses casos, é indispensável. A critério do órgão ambiental, o EIA pode ser solicitado para outros empreendimentos.

Também é exemplificativa a relação dos empreendimentos e atividades sujeitos ao licenciamento ambiental, vez que novamente a própria legislação remete à discricionariedade do órgão ambiental competente a definição de outros casos sujeitos a tal procedimento, levando em consideração as especificidades, os riscos ambientais, o porte e outras características do empreendimento ou atividade ${ }^{48}$.

Pelas finalidades a que se destinam, pode-se afirmar que o licenciamento ambiental e o EIA (juntamente com seu respectivo RIMA) são instrumentos de caráter preventivo, por meio dos quais se busca garantir que as medidas de controle adotadas nos empreendimentos sejam compatíveis com o desenvolvimento sustentável ${ }^{49}$.

48 Conforme disposto na Política Nacional de Meio Ambiente, instituída pela Lei Federal 6.938/81, artigo 10: "A construção, instalação, ampliação e funcionamento de estabelecimentos e atividades utilizadoras de recursos ambientais, considerados efetiva e potencialmente poluidores, bem como os capazes, sob qualquer forma, de causar degradação ambiental, dependerão de prévio licenciamento de órgão estadual competente, integrante do Sistema Nacional do Meio Ambiente - SISNAMA, e do Instituto Brasileiro do Meio Ambiente e Recursos Naturais Renováveis - IBAMA, em caráter supletivo, sem prejuízo de outras licenças exigíveis" (BRASIL, 1981). Essa lei foi regulamentada pela Resolução Conama 237/97, que dispõe no mesmo sentido e complementa que: "Artigo $2^{\circ}-(\ldots) \S 2^{\circ}$ - Caberá ao órgão ambiental competente definir os critérios de exigibilidade, o detalhamento e a complementação do Anexo 1, levando em consideração as especificidades, os riscos ambientais, o porte e outras características do empreendimento ou atividade" (CONAMA, 1997).

${ }^{49}$ Conforme previsto na Política Nacional de Meio Ambiente (Lei Federal 6.938/81), artigo $9^{\circ}$, incisos III e IV (BRASIL, 1981). 
A legislação serve de balizamento para definir linhas mestras, ficando a cargo do órgão ambiental definir a adequada aplicação daqueles enunciados.

A título de reflexão: a legislação prevê a exigibilidade do licenciamento, de EIA-RIMA e de audiências públicas, bem como define os critérios, requisitos e limitações a serem observadas na elaboração e na análise de um projeto; ou seja, a legislação traça as diretivas mínimas a serem seguidas para que o processo de licenciamento ambiental seja considerado regular.

Porém, os projetos, estudos e relatórios que serão efetivamente produzidos, analisados e discutidos são eminentemente técnicos, exigindo conhecimentos específicos que fogem da esfera jurídica e que, embora seguindo diretivas normativas, precisam ser avaliados individualmente no caso concreto, dadas as peculiaridades de cada empreendimento.

Por essa razão, há muitos aspectos que ficam por conta da discricionariedade do agente público que conduz o licenciamento ambiental, seja nos casos em que a própria legislação remete a uma subjetividade técnica, a ser preenchida no caso concreto a critério do órgão licenciador, ou mesmo nos casos em que a aplicação dos requisitos legais depende de uma avaliação que precisaria ser pautada no aspecto técnico.

No caso prático, como coloca Fink e Souza (2000, p. 72), não há como eliminar o aspecto discricionário:

impossível deixar de reconhecer certa reserva discricionária para a Administração Pública no processo licenciatório, havendo margem de liberdade, quando menos técnica, na escolha de uma dentre as múltiplas alternativas legais, com opção, a juízo do licenciador, de qual a mais vantajosa. 
Portanto, tem-se que o licenciamento ambiental contempla aspectos técnicos e jurídicos, e para respaldar a legitimidade das escolhas feitas pelo administrador público, no caso dos projetos sujeitos à apresentação de EIA-RIMA, está prevista a participação popular nas discussões a respeito desses estudos e do processo de licenciamento por ocasião das audiências públicas, além das discussões em plenária do Consema.

Nesse sentido, Moraes (2005) entende o licenciamento ambiental como um serviço público que deve realizar o balanço dos interesses e opiniões, as avaliações técnico-científicas e a participação pública visando à prestação administrativa de uma decisão de gestão ambiental para garantir o direito ao meio ambiente ecologicamente equilibrado.

Sendo um processo, constitui-se de fases sucessivas. Em geral, o licenciamento ambiental vaise desenvolvendo com a emissão de três tipos de licenças ambiental: a Licença Prévia (que aprova a viabilidade ambiental do empreendimento), a Licença de Instalação ou de Implantação (que aprova a implantação do empreendimento) e a Licença de Operação ou de Funcionamento (que permite o funcionamento do empreendimento) ${ }^{50}$.

Essas licenças são emitidas sucessivamente, a menos que se trate de regularização de fontes poluidoras já instaladas, quando exceções à regra geral são previstas pela legislação.

\footnotetext{
${ }^{50}$ Conforme previsto no Decreto Estadual paulista 8.468/76 (SÃO PAULO, 1976). A Resolução CONAMA 237/97 (CONAMA, 1997) conceituou cada uma dessas licenças: “Art. $8^{\circ}$ - O Poder Público, no exercício de sua competência de controle, expedirá as seguintes licenças: I - Licença Prévia (LP) - concedida na fase preliminar do planejamento do empreendimento ou atividade aprovando sua localização e concepção, atestando a viabilidade ambiental e estabelecendo os requisitos básicos e condicionantes a serem atendidos nas próximas fases de sua implementação; II - Licença de Instalação (LI) - autoriza a instalação do empreendimento ou atividade de acordo com as especificações constantes dos planos, programas e projetos aprovados, incluindo as medidas de controle ambiental e demais condicionantes, da qual constituem motivo determinante; III - Licença de Operação (LO) - autoriza a operação da atividade ou empreendimento, após a verificação do efetivo cumprimento do que consta das licenças anteriores, com as medidas de controle ambiental e condicionantes determinados para a operação".
} 
Especificamente no tocante à gestão da crise energética, vale lembrar que em 2001 foram editadas medidas provisórias para, em síntese, estudar e implantar medidas a serem tomadas para promover a redução do consumo e o incremento da geração de energia elétrica.

No que interessa à presente, em 15.05.2001 foi editada a Medida Provisória 2.147/01, que criou e instalou a Câmara de Gestão da Crise de Energia Elétrica, do Conselho de Governo, além de estabelecer diretrizes para programas de enfrentamento da crise de energia elétrica.

Àquela, seguiram-se edições e reedições de Medidas Provisórias com mesmo conteúdo até a Emenda Constitucional $32 / 2001^{51}$, que ao impor restrições às reedições de medidas provisórias, convalidou os atos praticados com base na Medida Provisória 2.198-4/2001.

Essas Medidas Provisórias estabeleceram que o processo de licenciamento de empreendimentos de geração, importação e transmissão de energia deveriam atender ao princípio da celeridade, determinando-se o prazo de 4 meses para a emissão de licenças para usinas termoelétricas e hidroelétricas (entre outros empreendimentos relacionados a geração e transmissão de energia elétrica) consideradas de pequeno potencial de impacto ambiental.

A Resolução do Conselho Nacional do Meio Ambiente (Conama) 279/01 regulamentou as normas editadas pelo Executivo Federal, prevendo as etapas do licenciamento e o conteúdo mínimo do Relatório Ambiental Simplificado a ser elaborado nesses projetos. A avaliação sobre o enquadramento dos projetos nesse procedimento ficou por conta do órgão ambiental.

Vamos, a seguir, tratar do processo de licenciamento ambiental conduzida pela SMA.

\footnotetext{
${ }^{51}$ A Medida Provisória 2.147/01 foi revogada e reeditada, sucessivamente, pelas Medidas Provisórias 2.148/01, 2.152/01 e 2.198/01, com suas reedições, até a edição da Emenda Constitucional 32/01.
} 


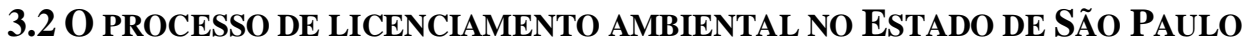

As usinas de geração de eletricidade acima de $10 \mathrm{MW}$, qualquer que seja a fonte de energia primária, estão sujeitas à elaboração de EIA-RIMA ${ }^{52}$.

A legislação paulista incluiu expressamente as termoelétricas como fonte de poluição, sem distinção em relação à potência instalada: "Para efeito de obtenção das Licenças Prévia, de Instalação e de Operação, consideram-se fontes de poluição: (...) XIV - termoelétricas",53.

Assim, de início, vale observar que a estrutura organizacional da SMA no período em estudo consistia no seguinte organograma ${ }^{54}$ :

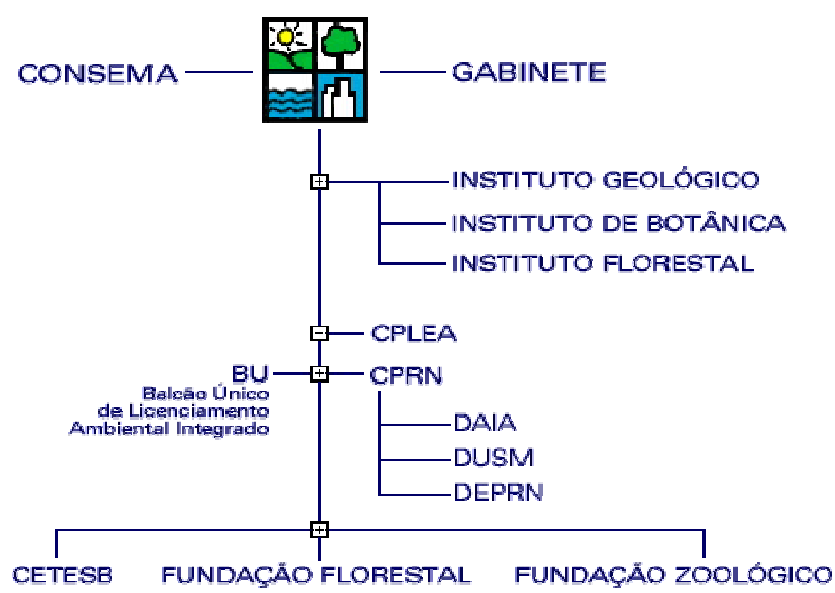

Figura 3 - Estrutura organizacional da SMA (SÃO PAULO, SMA, 2008).

\footnotetext{
${ }^{52}$ Conforme Resolução Conama 001/86, artigo 2º XI (CONAMA, 1986).

${ }^{53}$ Decreto Estadual paulista 47.397/02, artigo 57 (SÃO PAULO, 2002).

${ }^{54}$ A estrutura organizacional da SMA após as alterações promovidas pelo Decreto Estadual 54.653/09 (SÃO PAULO, 2009), consta do Anexo 2 para efeito comparativo.
} 
Embora tenham sido introduzidas alterações estruturais e organizacionais na $\mathrm{SMA}^{55}$ e na Cetesb $^{56}$ entre 2008 e 2009, serão adotados, para efeito metodológico, a estrutura e a nomenclatura existentes à época do recorte temporal delimitado para a presente pesquisa, bem como do projeto objeto do estudo de caso.

Além do aspecto metodológico para esta pesquisa, outro fator a ser considerado é que a nova estrutura do órgão ambiental estadual foi implantada muito recentemente: a Cetesb passou a ser a Companhia Ambiental do Estado de São Paulo, incorporando vários departamentos que eram da SMA, em agosto de 2009. Assim, há pouca base para sua avaliação.

O processo de licenciamento ambiental deve seguir os parâmetros previstos na legislação e, no caso da SMA, também as resoluções administrativas emanadas internamente que regulamentem ou detalhem os processos a serem analisados por aquela Secretaria ${ }^{57}$.

Dos órgãos que compunham a SMA antes das alterações introduzidas em 2009, serão objeto de análise detalhada aqueles que são necessariamente envolvidos e de forma direta com o licenciamento ambiental de empreendimentos de geração de energia: o Departamento de Avaliação de Impacto Ambiental (DAIA) e o Consema ${ }^{58}$.

\footnotetext{
${ }^{55}$ A estrutura organizacional da SMA foi alterada pelo Decreto Estadual 53.027/08 (SÃO PAULO, 2008), que foi alterado até chegar ao texto do Decreto Estadual 54.653/09 (SÃO PAULO, 2009c). Para efeito comparativo, a estrutura da SMA após o advento das normas está apresentada no Anexo 2 e as alterações implantadas pela legislação acima referida serão devidamente referenciadas ao longo do trabalho

${ }^{56}$ A estrutura organizacional e as atribuições da Cetesb foram alteradas pela Lei Estadual 13.542/09 (SÃO PAULO, 2009b).

${ }^{57} \mathrm{Na}$ época em estudo, o licenciamento ambiental na SMA com apreciação de EIA-RIMA seguia o roteiro disposto na Resolução SMA 42/94, não tendo sido editado, até setembro de 2009, nenhuma normativa atualizando os procedimentos em função das alterações introduzidas na SMA e na Cetesb.

${ }^{58}$ Observando-se que outros departamentos dentro da SMA, como o Departamento Estadual de Proteção de Recursos Naturais e o Departamento de Uso do Solo Metropolitano, assim como os órgãos externos à SMA (tais como aqueles competentes para tratar de patrimônio arqueológico, tombamento, comunidades indígenas, conselho gestor de áreas de proteção ambiental, entre outros) podem ou não ser envolvidos, dependendo das intervenções previstas pelo projeto. Mesmo quando participam do processo, esses órgãos ou departamentos atuam em partes específicas que compõem o licenciamento ambiental do empreendimento (tais como análise e
} 
O DAIA é um departamento da SMA com a atribuição de analisar os estudos ambientais de empreendimentos potencial ou efetivamente causadores de impacto ambiental significativo e os planos de recuperação para áreas degradadas apresentados para empreendimentos minerários, atuando também supletivamente no licenciamento de empreendimentos de pequeno impacto que não constituem fontes de poluição em municípios que não dispõem dos recursos para exercer o licenciamento ambiental ${ }^{59}$.

Para subsidiar a avaliação nas diversas esferas de conhecimento técnico, de acordo com os impactos projetados para o empreendimento em análise, o DAIA submete os estudos recebidos à avaliação específica dos departamentos especializados da Cetesb.

A estrutura da Cetesb comporta uma Diretoria de Engenharia, Tecnologia e Qualidade Ambiental, cujos departamentos consultados para apreciar aspectos especializados envolvidos no projeto em licenciamento são os seguintes: departamento de tecnologia de águas superficiais e efluentes líquidos; departamento de tecnologia do ar; departamento de desenvolvimento, tecnologia e riscos ambientais; departamento de análises ambientais; e departamento de tecnologia do solo, águas subterrâneas e resíduos sólidos ${ }^{60}$.

aprovação de autorizações para supressão de vegetação e intervenção em áreas de proteção de mananciais), mas não tratam da condução do processo de licenciamento como um todo.

${ }^{59}$ Com o advento do Decreto Estadual 53.027/09, o DAIA passou a fazer parte do Gabinete do Secretário, sendo composto por: (a) Centro de Avaliação de Empreendimento de Infra-Estrutura (composto pelo Núcleo Técnico de Saneamento; Núcleo Técnico de Empreendimentos Urbanísticos; Núcleo Técnico de Empreendimentos de Transporte); (b) Centro de Avaliação de Empreendimentos Industriais e Agropecuários (composto pelo Núcleo Técnico de Empreendimentos Energéticos; Núcleo Técnico de Agroindústria; Núcleo Técnico de Mineração; e Núcleo Técnico de Normas e Geoprocessamento). Mesmo com as alterações promovidas, o DAIA manteve, como uma de suas atribuições, a elaboração de pareceres técnicos relacionados ao licenciamento ambiental de projetos submetidos à SMA, de forma a dar embasamento à tomada de decisão do Secretário Adjunto. Além dessa atribuição, cabe ao DAIA desenvolver arcabouço técnico e metodológico de avaliação de impacto ambiental estabelecer critérios e propor normas para orientar a elaboração dos estudos de impacto ambiental a serem submetidos ao Departamento para fins de licenciamento.

${ }^{60}$ Conforme organograma da Cetesb na época adotada para estudo e mantida em setembro de 2009 (disponível em < http://www.cetesb.sp.gov.br/Institucional/documentos/organograma.pdf>. Acesso em 08.09.2008 e em 02.11.2009. 
Os pareceres específicos de cada departamento são consolidados pelo DAIA que, a partir daí, emite o Parecer DAIA favorável ou não à viabilidade ambiental do empreendimento. Nesse Parecer também são estabelecidas as condicionantes para as fases seguintes do licenciamento, bem como a previsão das medidas mitigadoras e compensatórias, entre outras exigências que tenham sido levantadas pelos diversos setores envolvidos.

A partir de então, o processo de licenciamento ambiental passa por um crivo de legitimidade: o estudo ambiental é submetido à discussão e deliberação pelos conselheiros do Consema.

O Consema foi criado junto ao gabinete do Governo ${ }^{61}$, tendo, entre outras atribuições, estimular a participação da comunidade no processo de preservação, melhoria e recuperação da qualidade ambiental e apreciar relatórios de impacto sobre o meio ambiente ${ }^{62}$.

O Consema é constituído pelo Presidente, Secretário Executivo, Plenário, Comissões Especiais e Câmaras Técnicas ${ }^{63}$. O seu Presidente é o Secretário de Meio Ambiente e o Conselho é integrado por trinta e seis membros, sendo metade constituída por representantes do Poder Público e a outra metade por representantes de segmentos diversos da sociedade ${ }^{64}$, de forma que sua apreciação confere um condão de legitimidade ao processo.

\footnotetext{
${ }^{61}$ Conforme Decreto Estadual 20.903/83 (SÃO PAULO, 1983).

${ }^{62}$ Conforme previsto no Regimento Interno do Consema, artigo $3^{\circ}$, incisos VII e VIII.

${ }^{63}$ Regimento Interno do Consema, artigo $5^{\circ}$.

64 Conforme Regimento Interno do Consema atualizado em 17.06.2008 (com os ajustes impostos pelo Decreto Estadual 53.027/2008 que, entre outras coisas, alterou sua composição, e com os acréscimos aprovados pelas Deliberações Consema 19/1998 e 32/2007), artigo $4^{\circ}$ - "O Conselho Estadual do Meio Ambiente é integrado pelos seguintes membros: I. o Secretário do Meio Ambiente, que é seu presidente; II. um representante da Coordenadoria de Planejamento Ambiental da Secretaria do Meio Ambiente; III. um representante da Coordenadoria de Biodiversidade e Recursos Naturais da Secretaria do Meio Ambiente; IV. um representante da Coordenadoria de Recursos Hídricos da Secretaria do Meio Ambiente; V. um representante da Cetesb; VI. um representante da Secretaria de Economia e Planejamento; VII. um representante da Secretaria de Agricultura e Abastecimento; VIII. um representante da Secretaria de Saneamento e Energia; IX. um representante da Secretaria da Saúde; X. um representante da Secretaria da Habitação; XI. um representante da Secretaria da Educação; XII. um representante da Secretaria da Cultura; XIII. um representante da Polícia Militar do Estado de São Paulo, da Secretaria da Segurança Pública; XIV. um representante da Secretaria da Justiça e Defesa da Cidadania; XV. um representante da Secretaria dos Transportes Metropolitanos; XVI. um representante da
} 
Verifica-se no Regimento Interno do Consema que o MPE-SP tem um assento fixo naquele Conselho, fazenda parte da metade representada pelos segmentos da sociedade civil.

O MPE-SP é representado no Consema pelo promotor ou procurador de justiça que esteja no cargo de coordenador do CAO-UMA ${ }^{65}$, tendo como suplente outro promotor que também faça parte desse Centro de Apoio. Desta forma, o MPE-SP participa diretamente desse momento do licenciamento ambiental dentro da própria estrutura administrativa da SMA.

A participação do MPE-SP no Consema é motivo de $\operatorname{críticas}^{66}$, mas é incentivada pela SMA.

De fato, quando o MPE-SP decidiu não indicar mais representantes daquela instituição para o

Consema, foi encaminhada ao Procurador Geral de Justiça e ao Conselho Superior do Ministério Público a Moção Consema 04/2000 aprovada na 155 Reunião Ordinária do Plenário, em 16.05.2000, pedindo a reconsideração decisão da instituição ministerial ${ }^{67}$.

Secretaria de Desenvolvimento; XVII. um representante da Secretaria dos Transportes; XVIII. um representante da Procuradoria Geral do Estado; XIX. um representante da Procuradoria Geral da Justiça do Estado de São Paulo; XX. um representante da Federação das Indústrias do Estado de São Paulo-FIESP; XXI. um representante do Conselho Regional de Engenharia, Arquitetura e Agronomia do Estado de São PauloCREA/SP; XXII. um representante da Associação Paulista de Municípios; XXIII. um representante da Ordem dos Advogados do Brasil - Secção São Paulo; XXIV. um representante eleito pelos sindicatos de trabalhadores urbanos do Estado de São Paulo, regularmente cadastrados na Secretaria do Meio Ambiente; XXV. um representante da Universidade de São Paulo - USP; XXVI. um representante da Universidade Estadual Paulista "Júlio de Mesquita Filho"; XXVII. um representante da Universidade Estadual de Campinas; XXVIII. um representante da Sociedade Brasileira para o Progresso da Ciência; XXIX. um representante do Instituto de Arquitetos do Brasil; XXX. um representante da Associação Brasileira de Engenharia Sanitária e Ambiental; XXXI. seis representantes eleitos pelas entidades com tradição na defesa do meio ambiente, regularmente cadastradas na Secretaria do Meio Ambiente" (grifo nosso).

${ }^{65}$ Com a alteração introduzida pelo Ato Normativo 533/08 do Conselho Superior do Ministério Público (2008), extinguiu-se o CAO-UMA, que passou a ser somente CAO, constituído, entre outras coordenadorias, pela coordenadoria de meio ambiente. Desta forma, a representação no Consema passou a ser atribuição do coordenador de meio ambiente do CAO, e não mais do chefe daquele centro de apoio.

${ }^{66}$ A participação do MPE-SP no Consema foi objeto de críticas, como as apontadas por Furriela (2002): (i) por participar de um conselho do Executivo que é objeto de seu controle; (ii) por muitas vezes seus membros se absterem de votar alegando necessidade de manter neutralidade, tornando desnecessária sua participação; (iii) por fazer parte do orçamento público e, no Consema, estar inserido no segmento da sociedade civil; (iv) pelo fato de o seu discurso por vezes legalista poder prejudicar os debates; e (v) por sua presença poder influenciar o rumo de uma discussão e decisão, tendo em vista a possibilidade de questionamento futuro de uma decisão do Conselho ao Judiciário por parte do MP.

67 Moção Consema 04/2000, de 16.05.2000: "O Conselho Estadual de Meio Ambiente, em sua 155 Reunião Plenária Ordinária, considerando a importância da participação de representantes do Ministério Público no 
O pedido contido nessa moção foi atendido pelo MPE-SP, que voltou a enviar representantes ao Consema e assim o faz até hoje.

Houve também uma ocasião em que o Consema recorreu ao MP para solicitar providências no sentido de que fosse embargado empreendimento considerado ilegal por aquele Conselho ${ }^{68}$, demonstrando o reconhecimento do Consema pelo papel do MP na tutela do meio ambiente.

Analisando-se a íntegra de todas as Deliberações e Moções Consema desde sua criação em 1983, até 2008, verifica-se que o MPE-SP, além de fazer parte daquele conselho e como tal participar das plenárias onde é deliberada a viabilidade ambiental dos empreendimentos que se encontram em fase de licenciamento, também participa de instâncias administrativas na formulação de procedimentos administrativos e integrando câmaras técnicas.

De fato, já em 1987 (portanto, antes da CF-88), o MPE-SP fez parte da comissão especial constituída no Consema para propor critérios de seleção dos RIMAs ${ }^{69}$. Desde então, foi incluído em todas as comissões e câmaras criadas naquele Conselho.

Consema, em virtude de sua luta para garantir a eficácia dos dispositivos constitucionais que dispõem sobre os interesses da sociedade e assegurar a preservação dos recursos naturais, apela a Vossas Excelências que reconsiderem a decisão desse Egrégio Conselho Superior do Ministério Público de não indicar representantes para continuar integrando o Conselho Estadual do Meio Ambiente".

${ }^{68}$ Conforme Deliberação Consema 22/87, de 13.02.1987, o Conselho decidiu "solicitar ao Ministério Público providências no sentido de embargar a construção do empreendimento imobiliário na península da Prainha de Peruíbe, uma vez que o mesmo afronta a lei”.

69 “Deliberação Consema 28/87, de 10.07.1987 (29 a Reunião Ordinária do Plenário do Consema): constituir comissão integrada pelo Dr. Miguel Noronha, da Secretaria de Obras, Dr. Édis Milaré, da Procuradoria Geral de Justiça, Dr. Dante Mariutti, da Federação das Indústrias do Estado de São Paulo, Dra. Nanuza Luiza de Menezes, da Sociedade Brasileira para o Progresso da Ciência, Dr. Marcos Sorrentino e Dr. Ivan Carlos Maglio, da Secretaria do Meio Ambiente, para propor critérios de seleção dos Relatórios de Impacto Ambiental - RIMAs, que deverão ser submetidos ao Consema”. 
Esses grupos constituem-se na Comissão para estabelecer normas e procedimentos de análise para os EIAs de empreendimentos já iniciados ${ }^{70}$ e nas Câmaras Técnicas de Energia e Saneamento, de Sistemas de Transporte e de Atividades Industriais para apreciar EIA-RIMAs de empreendimentos desses segmentos ${ }^{71}$.

No que tange à Câmara Técnica de Energia e Saneamento, foi a esta atribuída a função de apreciar, entre outras atividades, usinas de geração de eletricidade acima de $10 \mathrm{MW}^{72}$. Essa câmara, à semelhança das demais criadas dentro do Consema, foi composta por nove membros, entre os quais um é representante do $\mathrm{MP}^{73}$.

A estrutura e o processo de licenciamento ambiental da SMA conferem ainda ao MP a oportunidade de solicitar a realização de audiências públicas e, também, a de ser convidado para participar das audiências públicas, conforme previsto em normas federais ${ }^{74}$ e estaduais ${ }^{75}$.

\footnotetext{
${ }^{70}$ Deliberação Consema 17/89.

71 Essas Câmaras Técnicas foram criadas pela Deliberação Consema 32/91, de 24.07.1991, modificada sucessivamente pelas Deliberações Consema 40/91 e 09/92.

72 Deliberação Consema 32/91: “Artigo $1^{\circ}$ - Ficam criadas 3 (três) Câmaras Técnicas para apreciar Estudos de Impacto Ambiental e respectivos Relatórios de Impacto Ambiental que forem submetidos ao Consema, a saber: I - Câmara Técnica de Energia e Saneamento para apreciar EIA-RIMAs relativos às seguintes atividades: a. emissários subaquáticos de lançamento de efluentes; b. linhas de transmissão de energia elétrica, acima de 230 kW; c. obras hidráulicas para exploração de recursos hídricos tais como: barragens para fins hidroelétricos, acima de $10 \mathrm{MW}$, de saneamento ou de irrigação, retificação de cursos d'água, abertura de barras e embocaduras, transposição de bacias, diques; d. usinas de geração de eletricidade qualquer que seja a fonte de energia minerária acima de $10 \mathrm{MW}$ '.

73 Deliberação Consema 32/91: “Artigo 2 - As Câmaras Técnicas criadas pelo Artigo anterior terão a seguinte composição: I - Câmara Técnica de Energia e Saneamento: a. um representante da Coordenadoria de Planejamento Ambiental da Secretaria do Meio Ambiente; b. um representante da Secretaria de Energia e Saneamento; c. um representante da Secretaria de Planejamento e Gestão; d. um representante da Secretaria da Saúde; e. um representante da Associação Brasileira de Engenharia Sanitária e Ambiental; f. um representante ambientalista; g. um representante da Universidade; h. um representante dos Conselhos Municipais de Defesa do Meio Ambiente; i. um representante do Ministério Público."

${ }^{74}$ A Resolução Conama 009/87, que regulamenta a realização de audiências públicas, estabelece: "Artigo $2^{\circ}$ Sempre que julgar necessário, ou quando for solicitado por entidade civil, pelo Ministério Público, ou por 50 (cinqüenta) ou mais cidadãos, o Órgão de Meio Ambiente promoverá a realização de audiência pública”.

75 A Deliberação Consema 15/90, de 21.06 .1990 (53ª reunião ordinária da plenária do Consema), alterada parcialmente pela Deliberação Consema 50/92, estabelece: "Artigo $3^{\text {o }}$ - As Audiências Públicas serão convocadas pela Secretaria do Meio Ambiente - SMA ou por deliberação do Conselho Estadual do Meio Ambiente - Consema. Parágrafo primeiro - As Audiências Públicas poderão ser solicitadas por entidades da sociedade civil, por órgãos ou entidades do poder público estadual e municipal, pelo Ministério Público Federal e Estadual e por membros do Poder Legislativo".
} 
A organização estatutária do Consema prevê também, expressamente, que os "Promotores de Justiça das Comarcas na área de influência do empreendimento ou assunto em exame" deverão ser convidados a participar das audiências públicas, juntamente com outras autoridades, entidades ambientalistas e a imprensa ${ }^{76}$.

Esse mesmo dispositivo estatutário prevê que o MPE-SP é convidado para as audiências públicas também como membro do Consema ${ }^{77}$.

Conforme Fink (2009), as audiências públicas nem sempre se constituem em palcos isentos de discussão, daí não havendo motivos para o MP estar presente nessas ocasiões (informações verbais $)^{78}$. Para Seara Filho (2008), não é sempre que o MPE-SP comparece e, mesmo quando comparece, não é sempre que se inscreve para falar; ele entende que quando não há manifestação, é porque em princípio não há questionamentos (informações verbais) ${ }^{79}$.

Assim, pela estrutura existente, os representantes do CAO-UMA no Consema têm assento nas câmaras técnicas (momento de formulação de critérios e de análise dos EIA-RIMAs em fase preliminar do licenciamento ambiental), bem como nas plenárias do Consema e, assim como ocorre com os outros conselheiros, são convidados a participar das audiências públicas.

\footnotetext{
${ }^{76}$ Conforme Deliberação Consema 15/90, alterada parcialmente pela Deliberação Consema 50/92: "Artigo $6^{\circ}$ Serão convidados, dentre outros, para participar das Audiências Públicas: I - Senadores, Deputados Federais e Estaduais; II - Prefeitos e Câmaras de vereadores dos municípios da área de influência do empreendimento ou assunto em exame; III - Secretários de Estado; IV - Membros titulares e suplentes do Conselho Estadual do Meio Ambiente - Consema; V - Entidades ambientalistas cadastradas no Consema; VI - Outras entidades com sede nos municípios da área de influência do empreendimento ou assunto em exame; VII - Promotores de Justiça das Comarcas na área de influência do empreendimento ou assunto em exame; VIII - Outros órgãos do poder público que estejam participando do processo de análise do EIA-RIMA ou assunto em exame; IX - Imprensa estadual, regional ou local" (grifo nosso).

${ }^{77}$ Conforme artigo $6^{\circ}$, caput e inciso IV da Deliberação Consema 15/90, alterada parcialmente pela Deliberação Consema 50/92: "Serão convidados, dentre outros, para participar das Audiências Públicas: (...) IV - Membros titulares e suplentes do Conselho Estadual do Meio Ambiente - Consema".

${ }^{78}$ Informações fornecidas por Fink em entrevista realizada em 108.2008. Referências ao entrevistado constam do Anexo 6.

${ }^{79}$ Informações fornecidas por Seara em entrevista realizada em 15.11.2008. Referências ao entrevistado constam do Anexo 5.
} 
Paralelamente, os membros do MPE-SP atuantes nas promotorias locais são convidados a participar das audiências públicas juntamente com outras autoridades da região a ser afetada pela implantação e operação do empreendimento em discussão.

Embora não esteja prevista na estrutura organizacional do Consema e nem seja freqüente, também é possível a participação desses promotores das comarcas locais nas plenárias do Consema, juntamente com os representantes oficiais do MPE-SP naquele Conselho.

Para não comprometer o discernimento do promotor local, nem criar embaraços à sua liberdade de atuação, o representante do MPE-SP costuma se abster nas votações do plenário do Consema ${ }^{80}$, em atendimento à orientação institucional nesse sentido para não prejudicar a autonomia de decisão dos promotores das comarcas locais ${ }^{81}$.

Feita a análise do processo de licenciamento ambiental e do EIA-RIMA, tendo sido identificados momentos de participação do MPE-SP dentro da estrutura institucional da SMA, passa-se a analisar o MP. Primeiramente de forma genérica, tratando de institutos comuns para todos os MPs, para depois ser focado o MPE-SP.

\footnotetext{
${ }^{80}$ A abstenção do MPE-SP foi constatada por Furriela (2002) e por Goldemberg (2008) durante o período em que foi Secretário de Meio Ambiente, este em entrevista pessoal realizada em 17.12.2008 (referências ao entrevistado constam do Anexo 6).

${ }^{81}$ Conforme informação verbal de Fink (2009), em entrevista realizada em 12.08.2009. Referências ao entrevistado constam do Anexo 6.
} 


\section{O MINISTÉRIO PÚBLICO NA TUTELA DO MEIO AMBIENTE}

\subsection{EvoluÇão histórica e O Ministério Público brasileiro ATUAL}

Existem controvérsias doutrinárias a respeito das origens históricas do MP, se no Egito antigo, se na Roma Clássica, na Idade Média ou no Direito Canônico. No tocante ao MP moderno, faz-se referência à Ordenação francesa de 1302, embora também haja referência às ordenações portuguesas ou italianas.

Quaisquer que sejam as origens a serem adotadas, as raízes institucionais fincam-se no papel de procurador do rei ou de promoção de acusação penal ${ }^{82}$; não constam nesses registros antigos a atribuição conferida ao MP para realizar a fiscalização de órgãos da Administração Pública, nem mesmo a sua competência no tocante à tutela do meio ambiente ${ }^{83}$.

Também no Brasil, em sua origem, o MP estava ligado ao Brasil-Colônia e, portanto, ao Direito Lusitano, sendo que nos registros sobre cargos como Procurador da Coroa de Portugal junto ao Tribunal da Relação na Bahia (1609), Procuradores e posteriormente de promotores, sempre havia forte relação persecutória e repressiva relacionada ao direito penal ${ }^{84}$.

\footnotetext{
${ }^{82}$ Nesse sentido, Paes (2003), Mazzilli (2005) e Jatahy (2007).

${ }^{83}$ A proteção ambiental em alguns países, bem como do MP nessa função, foram analisadas no item 2.2.

${ }^{84}$ Conforme Paes (2003), Mazzilli (2005) e Jatahy (2007).
} 
As funções que estão relacionadas com esta pesquisa foram atribuídas pela CF-88, sendo que alguns instrumentos e competências foram antecedidas pela legislação infraconstitucional a partir da década de 1980. Portanto, diferentemente do MP na atuação penal, com longo histórico nacional e internacional, pouco se tem a falar da história do MP antes desse período no que se refere às atribuições que constituem objeto do presente estudo.

Conforme Santos (1990), o marco legal da proteção judicial do meio ambiente pelo MP é a Política Nacional do Meio Ambiente ${ }^{85}$, a mesma lei federal que havia previsto o licenciamento ambiental em nível nacional.

Essa norma atribuiu competência expressa e exclusiva para essa atuação: "O MP da União e dos Estados terá legitimidade para propor ação de responsabilidade civil e criminal por danos causados ao meio ambiente" ${ }^{, 86}$.

Em seu estudo, Santos (1990) constatou a participação decisiva do MPE-SP instituição nos conflitos de Cubatão na década de 1980. E também o seu papel fundamental na elaboração do anteprojeto da Lei da Ação Civil Pública, que antecipou atribuições que a CF-88 viria a ratificar: àquela instituição foi conferida a legitimidade para a defesa de interesses transindividuais (meio ambiente, consumidor e patrimônio cultural), além de ter-lhe atribuído competência para instrumentos jurídicos para o exercício dessas funções.

Conforme informa Queiroz (1993), com a primeira Lei Orgânica Nacional do Ministério Público $^{87}$, a instituição passou a ter um perfil mais uniforme, com conceituações, princípios, funções, garantias, vedações, instrumentos e organizações básicas comuns.

\footnotetext{
${ }^{85}$ Lei Federal 6.938/81 (BRASIL, 1981).

${ }^{86}$ Conforme consta na Lei Federal 6.938/81, artigo 14, $\S 1^{\circ}$ (BRASIL, 1981).
} 
Em 1985, com o advento da lei da ação civil pública ${ }^{88}$, foi ratificado o papel do MP na proteção judicial do meio ambiente, ao mesmo tempo em que se criou e também se incorporou instrumentos extraprocessuais do MP no cumprimento dessa função ${ }^{89}$.

A partir de então, o MP passou a se fazer sempre presente nas ações civis públicas ${ }^{90}$, quer como sujeito ativo da ação, quer como fiscal da lei, ou ainda como assistente litisconsorcial, das ações judiciais que envolvam a proteção do meio ambiente (FONTES, 2006).

Com a CF-88, o MP obteve garantias de Poder do Estado, independente dos três poderes (Executivo, Legislativo e Judiciário) $^{91}$, tanto em organização administrativa e de cargos e provimentos, quanto no exercício de funções.

No tocante ao cumprimento das atribuições de proteção ambiental e de fiscalização dos órgãos de gestão ambiental, a autonomia garantida ao MP visa a evitar que essa instituição fique sujeita a pressões de políticas públicas ou outras prioridades governamentais, diferentemente dos órgãos licenciadores que fazem parte do Poder Executivo.

\footnotetext{
${ }^{87}$ Lei Complementar Federal 40/81 (BRASIL, 1981b).

${ }^{88}$ Instituída pela Lei Federal 7.347/85 (BRASIL, 1985).

${ }^{89}$ Tratam-se, respectivamente, do inquérito civil e do termo de compromisso de ajustamento de conduta que serão analisados no item 4.1.2.

${ }^{90}$ Conforme previsto na Lei Federal 7.347/85 (BRASIL, 1985), artigo $1^{\circ}$, podem ser discutidos, em esfera de ação civil pública, as ações de responsabilidade por danos morais e patrimoniais causados ao meio-ambiente; ao consumidor; à ordem urbanística; a bens e direitos de valor artístico, estético, histórico, turístico e paisagístico; por infração da ordem econômica e da economia popular.

${ }^{91}$ Daí porque há autores que o chamam de quarto poder. Nesse sentido, cite-se Valladão (1984); "O Ministério Público se apresenta com a figura de um verdadeiro poder do Estado. Se Montesquieu tivesse escrito hoje o Espírito das Leis, por certo não seria tríplice, mas quádrupla, a divisão de poderes. Ao órgão que legisla, ao que executa, ao que julga, um outro acrescentaria ele: o que defende a sociedade e a lei - perante a Justiça, parta a ofensa de onde partir, isto é, dos indivíduos ou dos próprios poderes do Estado". São contrários a essa nomenclatura, entre outros, Gavronski (2005), Mazzilli (2005) e Jatahy (2007), por não constar no texto constitucional. Já Macedo Junior (1999b) entende que, embora não expresse com rigor técnico o status jurídico e político do MP pós CF-88, essa terminologia serve ao menos para salientar seu novo papel e posição perante os três altos graus de autonomia desta instituição perante os demais poderes e sua independência.
} 
É também a CF-88 que previu os princípios institucionais do MP (a partir do que essa instituição revisou sua própria estrutura e organização administrativa) e incluiu sob a égide constitucional os instrumentos que a legislação ordinária havia lhe conferido ${ }^{92}$.

Com esse arcabouço legislativo amparado nos princípios e garantias constitucionais, o MP passou a ter legitimidade para exercer papel representativo como instituição mediadora dos conflitos e interesses sociais, seja como defensor direto dos interesses sociais (sejam eles coletivos, difusos ou individuais homogêneos imbuídos de interesse social), seja como fiscal da resolução de conflitos, com funções muitas vezes exclusivas (MAZZILLI, 2005).

Conforme Macedo Junior (2000b),

(...) O MP é certamente uma das instituições brasileiras que tem apresentado maior grau de plasticidade e mudança no Brasil desde a descoberta. No âmbito das instituições que formam o Aparelho Judicial, tal observação parece ser ainda mais verdadeira. Em que pesem as profundas alterações sofridas pelo Judiciário brasileiro desde a descoberta até hoje, o Judiciário ainda é o Judiciário, isto é, uma esfera do poder estatal responsável pela interpretação e aplicação da lei. O Judiciário ainda é um "Poder do Estado".

(...) A mesma observação pode ser feita com relação à Polícia. Também aqui, ainda que sejam imensas as transformações pela quais passou a polícia judiciária no país nestes cinco séculos, ela ainda continua com a sua identidade básica, a saber, investigar e prevenir a ocorrência de crimes em nossa sociedade.

(...) Uma análise histórica, ainda que superficial, permite observar que o mesmo não ocorre com o Ministério Público.

Feitas essas constatações, cabem, nos próximos itens, ser analisados os referidos princípios institucionais e os instrumentos que foram conferidos ao MP.

\footnotetext{
${ }^{92}$ Esses tópicos serão analisados nos itens 4.1.1 e 4.1.2.
} 


\subsubsection{Princípios institucionais e mecanismos de controle da instituição}

Os princípios institucionais do MP são os seguintes: a unidade, a indivisibilidade e a independência funcional ${ }^{93}$. Para esclarecer esses conceitos, passamos a apresentar a seguir as lições de Mazzilli (2005) a respeito do assunto.

Por unidade, entende-se que cada MP é um só órgão, sob uma só direção administrativa, mantendo-se a independência de cada membro no exercício de suas funções. Essa regra se aplica ao mesmo MP, não valendo de um MP para outro ${ }^{94}$.

A indivisibilidade implica que os membros do MP fazem parte de uma corporação e como tal exercem a mesma função, de modo que os seus membros podem ser substituídos nas suas funções, na forma prevista pela lei, sem que haja alteração. Assim, pressupõe-se que quem exerce as funções é a instituição MP, não a pessoa física de um determinado promotor.

A independência funcional significa que cada membro, assim como cada órgão do MP, gozam de independência para exercer suas funções em face dos outros membros e órgãos da mesma instituição, sem hierarquia funcional. Por conta desse princípio institucional, é garantida a possibilidade de cada membro do MP tomar as próprias decisões com base na sua consciência jurídica, sem ser obrigado a se ater a ordens ou à influência de outros membros ou órgãos da mesma instituição, muito menos de instâncias externas.

${ }^{93}$ Conforme artigo 127, § 1º da CF-88: "São princípios institucionais do Ministério Público a unidade, a indivisibilidade e a independência funcional" (BRASIL, 1988)

${ }_{94}$ Conforme artigo 128 da CF-88, o MP abrange o MP da União (que por sua vez compreende o MP Federal, o MP do Trabalho, o MP Militar, o MP do Distrito Federal e Territórios) e o MP dos Estados (BRASIL, 1988). 
É com base no princípio da independência funcional que é possível ao promotor da comarca local onde se está pretendendo instalar um empreendimento indispor-se (judicial ou extrajudicialmente) acerca do licenciamento ambiental desse projeto, mesmo que este tenha sido submetido à apreciação do Conselho em que o outro membro do MPE-SP faça parte.

É ainda assegurada a essa instituição, a autonomia funcional e administrativa, que corresponde à liberdade que a instituição MP tem de tomar suas decisões em face de outros órgãos ou instituições do Estado ${ }^{95}$.

É importante distinguir a autonomia funcional e administrativa, que se refere ao posicionamento da instituição como um todo em relação aos demais órgãos e aos demais poderes, da independência funcional, que se refere individualmente ao membro ou ao órgão dentro do MP de atuar profissionalmente sem se subordinar a decisões de outros membros.

Sobre o modelo institucional do MP, Rei (2009) critica o fato de a atuação do MPE-SP junto ao Poder Executivo no licenciamento ambiental variar de promotor para promotor, não havendo uma linha de conduta única como instituição (informações verbais) ${ }^{96}$.

Em complementação, Rei (2009) destaca que, em sua experiência como gestor público na Cetesb, conheceu promotores que compreenderam que o relacionamento de parceria com o órgão ambiental é o melhor, inclusive, para o meio ambiente, pois por vezes se consegue equacionamento de passivos que, pela mera aplicação da legislação, talvez não fosse possível. Também conheceu promotores que parecem querer competir com o órgão ambiental, tanto no licenciamento, quanto na remediação de passivos e na aplicação de medidas sancionatórias.

\footnotetext{
${ }^{95}$ De acordo, respectivamente, com os parágrafos $2^{\circ}$ e $3^{\circ}$ do artigo 127 da CF-88 (BRASIL, 1988).

${ }^{96}$ Informações fornecidas por Rei em entrevista realizada em 16.12.2008. Referências sobre o entrevistado constam do Anexo 6.
} 
Sobre a falta de linha de atuação institucional do MPE-SP, como ex-coordenador do CAOUMA, Fink (2009) informou que já se elaborou uma ordem de prioridades temática dos empreendimentos que seriam acompanhados pelo MP (Planejamento Estratégico). Porém, assinala que não é vinculativo, pois pelos próprios princípios institucionais, os promotores das Comarcas locais têm autonomia para instaurar o inquérito civil para realizar o acompanhamento / avaliação que entenderem que o empreendimento exige ${ }^{97}$.

Contrapondo às atribuições, foram previstos mecanismos de controle da atuação dos membros do MP: a Corregedoria Geral do Ministério Público, o Conselho Superior do Ministério Público e o Conselho Nacional do Ministério Público, cuja estruturação e competências estão previstas nas leis orgânicas da instituição.

À Corregedoria Geral do Ministério Público compete realizar correições e inspeções nas Promotorias de Justiça e inspeções nas Procuradorias de Justiça (identificando eventuais abusos ou omissões de membros do MP), instaurar e presidir processos administrativos de caráter preliminar, propor o não vitaliciamento de promotores em estágio probatório e expedir recomendações não vinculativas.

O Conselho Superior do Ministério Público possui diversas funções administrativas mas, em temos de controle, pode ser destacada a atribuição que lhe foi conferida de rever e manifestarse a respeito do arquivamento de inquérito civil e de peças de informação que obrigatoriamente lhe são submetidos pelos promotores de justiça.

\footnotetext{
${ }^{97}$ Informações verbais fornecidas por Fink em entrevista realizada em 10.08.2009. Referências ao entrevistado constam do Anexo 6.
} 
Com a aprovação da Emenda Constitucional 45, foi criado o Conselho Nacional do Ministério Público, ao qual compete o controle da atuação administrativa e financeira dessa instituição e do cumprimento dos deveres funcionais de seus membros ${ }^{98}$.

A partir de então, os Conselhos Superiores do Ministério Público deixaram de ser a cúpula de decisão máxima dessa instituição, podendo algumas deliberações ser submetidas e revistas pelo Conselho Nacional do Ministério Público. Desta forma, também se criou uma instância recursal para as decisões saindo das esferas da organização de cada Estado.

Embora, no entender de Mazzilli (2005), mesmo antes da criação do Conselho Superior do Ministério Público já existiam mecanismos de freios e contrapesos para o MP, como o controle, em tese, exercido pelos membros da Ordem dos Advogados do Brasil ou do Poder Judiciário, além da possibilidade de o controle ser feito pelo questionamento de improbidade proposta por ação popular, entre outros mecanismos a que estão sujeitos os membros do MP.

Para Fink (2009), também há o controle relativamente comum exercido pelos próprios membros do MP entre si, por meio de denúncia, às vezes anônima, a respeito de irregularidades que estejam sendo praticadas por um colega, para que não desabonem a instituição (informação vebal) ${ }^{99}$.

\footnotetext{
${ }^{98}$ Entre as competências do Conselho Nacional do Ministério Público destacam-se, no que interessa ao presente estudo, apreciar a legalidade dos atos administrativos praticados por membros ou órgãos do MP da União e dos Estados e receber reclamações contra membros ou órgãos do MP da União ou dos Estados.

99 Informação fornecida por Fink em entrevista pessoal realizada em 10.08.2009. Referências sobre o entrevistado constam do Anexo 6.
} 


\subsubsection{Instrumentos judiciais e extraprocessuais do Ministério Público}

Para cumprir as atribuições que lhe foram conferidas pela $\mathrm{CF}-88$, especificamente no que se refere a questões ambientais, o MP pode adotar a alternativa tradicional de levá-las ao Judiciário (por meio da propositura de ação civil pública ou ação penal) ou, então, pode utilizar os instrumentos inovadores de que dispõe para dirimi-las extrajudicialmente.

Ao estudar a participação de diversos atores nos conflitos ambientais ocorridos em Cubatão na década de 1980, Santos (1990) destacou a atuação do MPE-SP e apontou para a falência do Poder Judiciário como foro de resolução de conflitos de modo geral e, especialmente, dos ambientais, como um fator relevante que propiciou a diferenciação da instituição ministerial.

Para De Mio, Ferreira Filho e Campos (2005), o MP representa os interesses da sociedade civil brasileira, ainda pouco mobilizada e comprometida com as questões ambientais, apresentando ainda as vantagens de possibilitar priorizar o paradigma ganhar-ganhar (ao invés

de ganhar-perder tradicional das demandas judiciais), permitindo negociação prévia e consenso, com mais agilidade, custos menos elevados e maior eficiência.

Conforme estudo feito por Fernandes (1999), o MP é autor de 96\% de todas as ações civis públicas ambientais em trâmite pelos tribunais do país. Sobre esse aspecto, Macedo Junior (2000) destaca que o MP passou a ter importante papel como instituição mediadora dos conflitos e interesses sociais, após ter ampliado a sua atuação de fiscalização e promoção dos interesses sociais e da justiça social por meio do seu envolvimento direto com os problemas sociais, especialmente fora do Judiciário. 
Em outra obra (1999a), esse autor havia constatado uma dupla realidade - o inchaço das demandas junto ao MP e o esvaziamento do Poder Judiciário como esfera decisória resultante da relevância de um canal institucionalizado para a defesa judicial dos interesses coletivos e, também e principalmente, para a promoção de um fortalecimento da cidadania.

De Mio, Ferreira Filho e Campos (2005) assinalam as vantagens da atuação do MP ao evitar que o conflito ambiental chegue ao Poder Judiciário, dada a dificuldade decorrente da multiplicidade e da complexidade de interesses envolvidos, entre os quais ligações entre questões econômicas, políticas e sociais, incertezas científicas e soluções que requerem a participação de diferentes setores da sociedade.

Gavronski (2005) aponta outras vantagens, com destaque para a possibilidade de membros da sociedade atingidos pela questão ambiental em discussão terem otimizada a possibilidade de intervir no equacionamento da situação lesiva, além do debate mais aprofundado sobre as formas de solução, inclusive em situações que costumam envolver inúmeras variantes relacionadas a áreas do conhecimento estranhas ao direito.

Yoshida (2005) reconhece as dificuldades do Judiciário em resolver as questões ambientais, atribuindo parte dessas dificuldades à própria estrutura federativa do Brasil com três níveis de poder (federal, estadual / distrital e municipal) e ao complexo sistema constitucional de competências legislativa, administrativa e jurisdicional, que seriam responsáveis pelo surgimento e judicialização de conflitos institucionais e federativos que dificultariam ou procrastinariam a prestação jurisdicional. 
Nesse cenário de problemas do Poder Judiciário para dirimir os conflitos ambientais, dois instrumentos à disposição do MP para a solução extrajudicial desses conflitos merecem destaque: o inquérito civil e o TAC.

O inquérito civil é um procedimento investigatório cuja instauração, condução e arquivamento são de competência exclusiva do $\mathrm{MP}^{100}$. Inicialmente previsto por legislação ordinária, foi consagrado pela $\mathrm{CF}-88^{101} \mathrm{e}$, a partir daí, inserido em diversas outras normas ${ }^{102}$.

O objetivo do inquérito civil é o de colher elementos de convicção para que os membros do MP identifiquem ou não a hipótese em que a lei exige propositura de ação civil pública. Por essa razão, a sua instauração é dispensável, podendo o MP propor diretamente a ação judicial, se entender que tem os elementos aptos para tal.

Mazzilli (2005b) alerta que, como o inquérito civil é ainda um instrumento relativamente novo, por vezes pode não estar sendo usado em sua plenitude e, em outros, seja indevidamente instaurado causando grande desgaste às pessoas investigadas, ou ainda ser sede de possíveis ilegalidades ou irregularidades pelo membro do MP que o preside. Observada a importância de que o inquérito civil seja presidido com elevado senso de responsabilidade, o autor reconhece que é um instrumento valioso conferido ao MP.

${ }^{100} \mathrm{O}$ inquérito civil foi previsto inicialmente na Lei da Ação Civil Pública (Lei Federal 7.347/85), artigo $8^{\circ}, \S$ 1': "O Ministério Público poderá instaurar, sob sua presidência, inquérito civil, ou requisitar, de qualquer organismo público ou particular, certidões, informações, exames ou perícias, no prazo que assinalar, o qual não poderá ser inferior a 10 (dez) dias úteis".

101 Conforme artigo 129 da CF-88: "São funções institucionais do Ministério Público: (...) III - promover o inquérito civil e a ação civil pública, para a proteção do patrimônio público e social, do meio ambiente e de outros interesses difusos e coletivos".

${ }^{102}$ Nas que interessam ao presente estudo, destacamos a Lei Orgânica Nacional do MP (Lei Federal 8.625/93) e a Lei Orgânica do MP da União (Lei Complementar Federal 75/1993). 
O inquérito civil, uma vez instaurado, pode ser encerrado por meio da propositura de ação civil pública ou então ser arquivado, caso em que essa decisão deverá ser fundamentada e submetida à homologação pelo Conselho Superior do Ministério Público. O arquivamento pode se dar quando, encerradas as diligências, o promotor de justiça entender que inexistam elementos para a propositura de ação civil pública ou, então, se houver celebração de TAC ${ }^{103}$.

Nessas situações, o Conselho Superior do Ministério Público tem as seguintes opções: homologar o arquivamento, converter o julgamento em diligência para a coleta de novos elementos de convicção, mandar desmembrar as investigações, ou ainda recusar o arquivamento e determinar que a ação seja proposta por outro membro do $\mathrm{MP}^{104}$.

O TAC é uma espécie de composição da lide ${ }^{105}$ entre as partes envolvidas no conflito, consistente num acordo formal por meio do qual o causador do dano assume o dever de adequar a sua conduta às exigências legais sob pena de incorrer nas sanções previstas nesse mesmo instrumento.

No caso do MP, o TAC pode ser celebrado na esfera judicial ou extrajudicial; naquela, dependerá de homologação do juiz, nesta, caberá a homologação ao Conselho Superior do Ministério Público. É possível também o órgão de gestão ambiental assinar junto esse instrumento, para que o equacionamento seja feito envolvendo-se a Administração Pública.

\footnotetext{
${ }^{103}$ De acordo com o estabelecido na Lei Federal 7.347/85 (BRASIL, 1985).

${ }^{104}$ Lei da Ação Civil Pública (Lei Federal 7.347/85, artigo 9º (BRASIL, 1985).

105 O TAC foi previsto inicialmente pelo Código de Defesa do Consumidor (Lei Federal 8.078/90), a partir do que foi incluído o $\S 6^{\circ}$ no artigo $5^{\circ}$ da Lei da Ação Civil Pública (Lei Federal 7.347/85): "Os órgãos públicos legitimados poderão tomar dos interessados compromisso de ajustamento de sua conduta às exigências legais, mediante cominações, que terá eficácia de título executivo extrajudicial”.
} 
Uma vez celebrado, com o preenchimento dos requisitos de formalidade e conteúdo ${ }^{106}$, o TAC constitui-se em título executivo extrajudicial ${ }^{107}$, que pode ser acionado para provocar a aplicação das sanções nele previstas, caso o compromitente não cumpra suas obrigações.

As vantagens do TAC na solução de conflitos ambientais são ressaltadas por Fink e Pereira (1996), para quem a ação civil pública representa uma solução desgastante, cara e difícil para o conflito ambiental. Desta forma, eles recomendam que, antes de se lançar mão dessa alternativa, deve-se buscar a negociação, da qual sairão todos muito mais fortalecidos do que se fossem obrigados a obedecer a um comando frio e inexorável de uma sentença.

Mesmo quando a questão ambiental já chegou ao Judiciário, Mancuso (2007) identifica vantagens de se celebrar um TAC ao invés de se aguardar a sentença. A título de exemplo, ele assinala que há situações em que a não celebração de acordo vai contra a tutela do meio ambiente, como no caso de uma indústria poluidora que, fazendo prova de que já estão encomendados os equipamentos necessários, propõe-se a instalá-los em prazo inferior ao que demoraria para que uma decisão judicial o obrigasse a tomar tal atitude.

Do que fundamenta a assertiva de que, nessas ações, interessa menos 'vencer' do que obter, de forma menos onerosa ou menos impactante, a melhor tutela para o conflito judicializado, o que seria feito por meio do acordo, instrumentalizado num TAC.

\footnotetext{
106 O TAC contém as seguintes informações básicas: os dados das partes compromissadas e dos respectivos representantes legais (verifica a legitimidade daquele que estiver a assinar o instrumento); o prazo de vigência do compromisso; a descrição detalhada de seu objeto visando à reparação integral do dano; as multas que podem ser aplicadas à pessoa física ou jurídica compromissada em caso de descumprimento; e o foro competente para dirimir litígios entre as partes.

${ }^{107}$ Título executivo extrajudicial é, de forma simplificada, um documento que confere crédito líquido, certo e exigível, permitindo a direta exeqüibilidade de uma pretensão.
} 
Daí concluem De Mio, Ferreira Filho e Campos (2005),

em conjunto, o inquérito civil e o TAC firmaram-se como instrumentos efetivos na resolução de conflitos ambientais, representando o diferencial na atuação do Ministério Público, em relação a outras instituições de gestão e fiscalização ambiental, também legitimadas para firmar o TAC.

Enfim, as vantagens da atuação do MP na gestão dos conflitos ambientais são amplamente reconhecidas pela doutrina, bem como a validade dos instrumentos de que dispõe.

A seguir, o estudo se deterá a avaliar a estrutura institucional dessa instituição, com base na qual se faz o acompanhamento e na fiscalização de trabalhos dos órgãos administrativos na condução do licenciamento ambiental ${ }^{108}$.

\subsection{A estrutura institucional do Ministério Público do Estado de SÃo Paulo}

Seguindo a estrutura geral prevista pela Lei Orgânica Nacional do MP, o MPE-SP é composto pelos seguintes órgãos ${ }^{109}$ :

\begin{tabular}{|l|l|}
\hline Órgãos da Administração Superior & $\begin{array}{l}\text { Procuradoria Geral de Justiça, Colégio de Procuradores } \\
\text { de Justiça, Conselho Superior do Ministério Público, } \\
\text { Corregedoria Geral do Ministério Público }\end{array}$ \\
\hline Órgãos da Administração & Procuradorias de Justiça e Promotorias de Justiça \\
\hline
\end{tabular}

\footnotetext{
${ }^{108}$ Neste trabalho nos deteremos à descrição específica da estrutura do MP paulista, considerando-se que (i) é essa a instituição cuja atuação será analisada em profundidade; e (ii) a sua estrutura é fundamentalmente a mesma descrita na legislação federal, não havendo necessidade de se duplicar o descritivo.

${ }^{109}$ Conforme previsto na Lei Orgânica Nacional do MP (Lei Federal 8.625/93), artigos $5^{\circ}$ a $8^{\circ}$, prevendo as estruturas dos MPEs.
} 


\begin{tabular}{|l|l|}
\hline Órgãos de Execução & $\begin{array}{l}\text { Procurador Geral de Justiça, Colégio de Procuradores } \\
\text { de Justiça, Conselho Superior do Ministério Público, } \\
\text { Procuradores de Justiça, Promotores de Justiça }\end{array}$ \\
\hline Órgãos auxiliares & $\begin{array}{l}\text { Centros de Apoio Operacional, Comissão de } \\
\text { Concursos, Centro de Estudos e Aperfeiçoamento } \\
\text { Funcional, órgãos de apoio técnico e administrativo e } \\
\text { estagiários }\end{array}$ \\
\hline
\end{tabular}

Embora a configuração de sua estrutura tenha sido dado pela legislação federal, aplicando-se a todos os Estados da Federação e do Distrito Federal, merece ser destacado que o MPE-SP é exemplar em relação às instituições ministeriais de outros Estados, tanto no que se refere à tutela do meio ambiente, quanto no que se relaciona à fiscalização da Administração Pública no exercício de funções essenciais.

A chefia do MPE-SP cabe ao Procurador Geral de Justiça. À Procuradoria Geral de Justiça e ao Colégio de Procuradores de Justiça (constituído por todos os Procuradores de Justiça efetivos do Estado) compete tratar principalmente de questões administrativas relativas à gestão da instituição e de seus membros.

O Conselho Superior do Ministério Público, conforme visto no item 4.1.1, tem, entre outras atribuições, sugerir recomendações sem caráter vinculativo aos órgãos do MP para o desempenho de suas funções e aprimoramento dos serviços, também lhe competindo avaliar pedidos de arquivamento de inquéritos civis propostos pelos promotores de justiça do Estado e os recursos interpostos pelos particulares em face da instauração desse procedimento ${ }^{110}$.

\footnotetext{
${ }^{110}$ Conforme a Lei da Ação Civil Pública, Lei Federal 7.347/85 (BRASIL, 1985) e a Lei Estadual paulista 734/93 (SÃO PAULO, 1993).
} 
No Estado de São Paulo, o Conselho Superior do Ministério Público pode também deliberar sobre a participação de membros do MP em organismos estatais de defesa do meio ambiente $^{111}$.

À Corregedoria Geral do Ministério Público, também já referenciado no item 4.1.1, cabe orientar e fiscalizar as atividades funcionais e de conduta dos membros do MP, realizando correições e visitas de inspeção em Promotorias de Justiça, acompanhar o cumprimento de metas por ela estabelecidas, instaurar processos administrativos, aplicar sanções e remeter ao Conselho Superior do Ministério Público relatório circunstanciado sobre a atuação pessoal e funcional dos promotores em estágio probatório (ou seja, aqueles que se encontram nos primeiros anos de atuação, não tendo sido ainda considerados efetivados).

A Procuradoria de Justiça é constituída por Procuradores de Justiça, os quais são promotores de justiça com maior experiência que são promovidos por critérios de antiguidade e de merecimento para atuarem na segunda instância junto ao Tribunal de Justiça.

O MPE-SP conta hoje com promotorias de justiça espalhadas por todo o Estado, junto às Comarcas judiciais, sendo representadas por Promotores de Justiça locais. Para a tutela do meio ambiente, o MPE-SP atribui a um ou a um grupo de promotores de justiça, o papel de atuarem de forma especializada em assuntos relativos à defesa do meio ambiente. Daí a existência de Promotorias de Justiça do Meio Ambiente em todas as Comarcas do Estado ${ }^{112}$.

\footnotetext{
${ }^{111}$ Conforme previsto na Lei Estadual 734, de 26.11.1993, artigo 36, XVII (SÃO PAULO, 1993).

112 Em 2009, pelo Ato da Procuradoria Geral de Justiça 552, de 04.09.2009, foram criados alguns grupos especializados de atuação, como os Grupos de Atuação Especial de Defesa do Meio Ambiente denominados de GAEMAs. Foram criados 6 desses grupos especiais no Estado: Vale do Paraíba, Litoral Norte, Pardo, Vale do Ribeira, Baixada Santista e Paranapanema. Para esses grupos são destacados promotores de justiça para a atuação especializada em meio ambiente, com prejuízo de suas funções originais, ou seja, afastados de suas atuações originais, para se dedicarem exclusivamente à nova função.
} 
Já os órgãos auxiliares não se constituem órgãos propriamente ditos do $\mathrm{MP}$, por não exercerem atribuições funcionais por integrantes da carreira, sendo mais serviços que fornecem o suporte do que órgãos propriamente ditos (MAZIILLI, 2005).

Entre os órgãos auxiliares, o MPE-SP dispõe do Centro de Estudos e Aperfeiçoamento Funcional - Escola Superior do Ministério Público, que tem por finalidade oferecer aprimoramento profissional e cultural de seus Membros, Auxiliares e Servidores ${ }^{113}$. Oferece cursos de especialização e extensão em diversas áreas do Direito, além de Curso de Adaptação para promotores de justiça recém-ingressos na carreira.

A Comissão de Concursos trata dos assuntos relacionados ao ingresso de novos membros para a instituição (o que é feito por meio de concurso público).

Como apoio técnico, o MPE-SP tem centros de apoio operacional coordenados por promotores ou procuradores de justiça e que contam com os chamados assistentes técnicos da Promotoria, que são profissionais nomeados por indicação para dar subsídio técnico não jurídico aos membros da instituição.

Na questão ambiental, destacamos o CAO-UMA, que é um órgão auxiliar da ProcuradoriaGeral de Justiça do Estado de São Paulo que dá apoio técnico e logístico aos Promotores e Procuradores de Justiça na atuação institucional de tutelar o meio ambiente ${ }^{114}$.

\footnotetext{
${ }^{113}$ Previsto na Lei Orgânica Estadual do Ministério Público (Lei Estadual 734, de 26.11.1993), em seus artigos $8^{\circ}$ e 53 e seguintes. O conteúdo dos cursos oferecidos consta do sítio 〈http://www.espm.sp.gov.br〉. Acesso em 28.09.2009.

${ }^{114}$ Em 2008, foi criado o Centro de Apoio Operacional à Execução, pelo Ato Normativo PGJ 532/08, para oferecer suporte técnico-operacional e serviços de informação/inteligência às Promotorias e Procuradorias de Justiça do Estado de São Paulo, e agilizar a prestação de serviços de apoio técnico e científico requisitados por membros do MP para a instrução de procedimentos de sua alçada. Pelo Ato Normativo PGJ 533, de 29.04.2008, houve nova alteração na estrutura dos CAOs: ao invés de CAOs especializados, permaneceram 3 CAOs: cível, criminal e de execução. No CAO cível foram criadas coordenadorias, entre as quais se inclui a de meio
} 
Até 2003, denominava-se CAO de Meio Ambiente, existindo um CAO de Habitação e Urbanismo em separado. Ambos foram unificados e daí a denominação CAO-UMA ${ }^{115}$.

Os assistentes técnicos dos Centros de Apoio têm, entre outras atribuições, analisar estudos técnicos de processos de licenciamento ambiental e subsidiar os Promotores de Justiça com elementos técnicos para o desempenho de suas funções.

O Promotor ou Procurador de Justiça que coordena o CAO-UMA (ou seu suplente) é aquele que representa o MPE-SP no Consema, como conselheiro.

Além da CF-88, das Leis Orgânicas e outras normas da legislação esparsa, o MP conta com diretivas de atuação emanadas pelos Órgãos de Execução. No caso do MPE-SP, este conta com as diretivas dadas pelas Resoluções do Conselho Superior do Ministério Público, existindo também jurisprudência cadastrada nesse mesmo órgão.

Nos atos normativos do Conselho Superior do MPE-SP, não foram verificadas diretivas específicas ao acompanhamento do licenciamento ambiental e/ou à fiscalização de órgãos de gestão ambiental, nem sobre empreendimentos ou programas em particular.

ambiente. Desta forma, as atribuições do antigo CAO-UMA foram distribuídas entre a coordenadoria de meio ambiente do CAO Cível e o Centro de Apoio Operacional à Execução. Como as alterações foram introduzidas após o período adotado como recorte temporal, essas alterações estão apenas referenciadas, de forma que a análise considerará fundamentalmente o CAO-UMA.

115 O CAO-UMA foi criado pelo Ato Normativo PGJ 303, de 6.02.2003, pelo qual o CAO de meio ambiente foi unificado com o CAO de habitação e urbanismo. 
No entanto, Fink (2009) confirmou que o MPE-SP fiscaliza com mais ênfase os projetos sobre os quais haja algum programa político ou suspeita de pressão sobre os órgãos licenciadores, para evitar que etapas importantes do licenciamento ambiental sejam atropeladas visando a atender a essas pressões, em prejuízo da legalidade e do meio ambiente, como no caso do licenciamento das termelétricas na época do PPT (informações verbais) ${ }^{116}$.

Em nível nacional, verificamos que o acompanhamento do licenciamento ambiental desde o seu início foi institucionalmente incentivado como ação preventiva de danos ambientais irreversíveis, conforme orientações constantes do "Roteiro para atuação do Ministério Público Federal em licenciamentos ambientais elaborado pela $4^{\mathrm{a}}$ Câmara de Coordenação e Revisão Meio Ambiente e Patrimônio Cultural” da Procuradoria Geral da República (2005).

Assim, o MPE-SP tem a seu dispor a legitimidade e os instrumentos jurídicos para acompanhar e questionar o processo de licenciamento ambiental, de forma independente de políticas públicas ou de programas de incentivo governamental. Vamos a seguir analisar a base jurídica para a realização dessa função.

\footnotetext{
${ }^{116}$ Informações fornecidas por Fink em entrevista realizada em 10.08.2009. Referências sobre o entrevistado
} constam do Anexo 6. 


\subsection{BASE JURÍDICA PARA A ATUAÇÃO NO LICENCIAMENTO AMBIENTAL}

O "Ministério Público é instituição permanente, essencial à função jurisdicional do Estado, incumbindo-lhe a defesa da ordem jurídica, do regime democrático e dos interesses sociais e individuais indisponíveis" ${ }^{\prime 17}$.

Entre suas funções institucionais se inclui a de zelar pelo efetivo respeito dos Poderes Públicos e dos serviços de relevância pública aos direitos assegurados na $\mathrm{CF}$, promovendo as medidas necessárias à sua garantia ${ }^{118}$.

Essa é a base constitucional para a participação do MP na esfera de atividades exercidas pela Administração Pública, como na condução de processos de licenciamento ambiental.

Isso porque o licenciamento ambiental, ao mesmo tempo em que consiste em um instrumento de serviço público visando ao direito constitucionalmente garantido para todos ao meio ambiente ecologicamente equilibrado, o licenciamento ambiental está sujeito à fiscalização do MP, com base na atribuição inovadora conferida pela CF-88 ao MP.

O meio ecologicamente equilibrado é garantido pela CF-88 como um direito de todos, ao mesmo tempo em que é um dever do Poder Público e da coletividade protegê-la para as presentes e para as futuras gerações, sendo o licenciamento ambiental um instrumento de relevância para assegurar aquele direito.

\footnotetext{
${ }^{117}$ CF-88, artigo 127, caput (BRASIL, 1988).
}

${ }^{118}$ CF-88, artigo 129, inciso II (BRASIL, 1988). 
Esse perfil inovador foi detalhado pelo Estatuto do Ministério Público da União, pelo qual foi assegurada a participação dessa instituição: (i) como instituição observadora, conforme estabelecido em ato do Procurador-Geral da República, em qualquer órgão da administração pública direta, indireta ou fundacional da União, que tenha atribuições correlatas às funções da Instituição; e (ii) nos órgãos colegiados estatais, federais ou do Distrito Federal, constituídos para defesa de direitos e interesses relacionados com as funções da Instituição ${ }^{119}$.

A Lei Orgânica Nacional do Ministério Público ${ }^{120}$, assim como a Lei Orgânica do Estado de São Paulo ${ }^{121}$, contemplaram nesse exercício de defender os direitos assegurados nas Constituições Federal e Estadual, os órgãos da Administração Pública direta ou indireta, os concessionários, permissionários e entidades delegadas de serviços de relevância pública.

Mazzilli (2005b) destaca que as referidas normas $^{122}$ regulamentam as atribuições constitucionais e exemplifica que, entre os serviços públicos ou de relevância pública, incluem-se aqueles exercidos pela administração direta ou indireta, como empresas públicas, fundações públicas, autarquias, concessionários ou permissionários, entidades que exerçam funções delegadas ou executem serviços de relevância pública, meios de comunicação social, agências reguladoras de energia elétrica, telecomunicações, petróleo, saúde, entre outros.

\footnotetext{
${ }^{119}$ Lei Orgânica do MP da União (Lei Complementar Federal 75/93), artigo 6º parágrafos primeiro e segundo, respectivamente (BRASIL, 1993).

${ }^{120}$ Lei Federal 8.625/93, artigo 26 (BRASIL, 1993).

${ }^{121}$ Lei Complementar Estadual 734/93, artigo 103 (BRASIL, 1993).

${ }^{122}$ Lei Orgânica do MP da União (Lei Complementar Federal 75/93), artigos $8^{\circ}$ e 12-15; Lei Orgânica Nacional do MP (Lei Federal 8.625/93, artigo 27, parágrafo único).
} 
Proença (2001, p. 92-93) destaca que essas normas infraconstitucionais, ao regulamentarem o estabelecido no inciso II do artigo 129 da CF- $88^{123}$, apontaram para o intuito de

(...) fazer o MP tomar parte no debate público sobre serviços públicos e de relevância pública, na tentativa de influir administrativamente na gestão dos mesmos, isto é, extrajudicialmente, de preferência de maneira preventiva, relegando para uma segunda etapa a adoção de módulos de responsabilização pelo desrespeito ao direito assegurado pela Constituição Federal.

No entanto, esse autor considera essa função ainda incipiente dentro do MP e identifica os seguintes obstáculos para uma atuação mais eficiente por parte dessa instituição: a persistência de uma mentalidade política e jurisdicional conservadora no seio dessa instituição quando seria necessária a constituição de uma nova postura institucional, a sua frágil articulação com os setores da sociedade que se propõe a representar, a inexistência de uma visão institucional estratégica claramente definida e o insuficiente aparelhamento de seus processos investigatórios quando seria necessário um suporte material suficiente.

Salles (2009) concorda que a atribuição prevista no inciso II do artigo 129 da CF-88 é exercida de forma menos sistematizada do que seria desejável pelo MPE-SP, cujos membros estão mais familiarizados com a atribuição prevista no inciso seguinte, que é o da instauração de inquéritos e da propositura de ações civis públicas (informações verbais) ${ }^{124}$.

\footnotetext{
123 Lei Orgânica do Ministério Público da União: “Artigo 13. Recebidas ou não as informações e instruído o caso, se o Procurador dos Direitos do Cidadão concluir que direitos constitucionais foram ou estão sendo desrespeitados, deverá notificar o responsável para que tome as providências necessárias a prevenir a repetição ou que determine a cessação do desrespeito verificado"; "Artigo 14. Não atendida, no prazo devido, a notificação prevista no artigo anterior, a Procuradoria dos Direitos do Cidadão representará ao poder ou autoridade competente para promover a responsabilidade pela ação ou omissão inconstitucionais".

${ }^{124}$ Informações fornecias por Salles em entrevista realizada em 08.10.2009. Referências sobre o entrevistado constam do Anexo 6.
} 
Em seu estudo, Salles (1992) havia ressaltado que a atribuição do artigo 129, II da CF-88 não contém apenas um significado de atuação processual, mas inclui uma atividade fiscalizatória geral a cargo do MP. Aquela instituição pode não somente levar a questão ao Poder Judiciário para que este venha a dirimi-la, mas também poderá atuar extrajudicialmente, exercendo seu poder de polícia e, neste caso, como mediador de conflitos autônomo e independente.

Sobre críticas à falta de aparelhamento do MP na tutela dos interesses difusos, que requerem conhecimentos especializados, Mancuso (2004) defende que o MP brasileiro tem uma estrutura legal, organizacional e funcional considerada, por seus membros, como sendo completa e diferente da existente no Direito estrangeiro.

Entre outros argumentos, ele destacou a larga tradição de atuação daquela instituição na esfera cível, a crescente legitimação atribuída àquela instituição em sede de tutela de interesses difusos $^{125}$, a criação de curadorias especializadas em cada comarca do Estado de São Paulo para a adequada atribuição para a proteção e defesa, no plano administrativo, do meio ambiente, assim como dos outros direitos difusos e coletivos.

Com o que se alinha Fink (2009), para quem o MPE-SP conta com estrutura e apoio técnico para atuar ativamente em questões ambientais, inclusive para sustentar embates técnicos que surjam com a avaliação das questões ambientais (informações verbais) ${ }^{126}$.

\footnotetext{
${ }^{125}$ Esse autor se refere à Política Nacional de Meio Ambiente (Lei Federal 6.938/81), à Lei da Ação Civil Pública (Lei Federal 7.347/85), à Lei Orgânica Nacional do Ministério Público (Lei Federal 8.625/93) e à Lei Orgânica do MP do Estado de São Paulo (Lei Complementar Estadual 734/93).

${ }^{126}$ Informações fornecias por Fink em entrevista realizada em 10.08.2009. Referências sobre o entrevistado constam do Anexo 6.
} 
Especificamente no que tange à proteção do meio ambiente, a Política Nacional do Meio Ambiente previu a legitimidade do MP para a tutela judicial em casos de danos ambientais ${ }^{127}$ e a Lei da Ação Civil Pública ${ }^{128}$ previu a sua atuação como fiscal da lei quando não interviesse como parte ativa ${ }^{129}$. As Leis Orgânicas regulamentaram essas atribuições ${ }^{130}$.

Para Jatahy (2007), essa atividade de controle dos atos do Poder Público abriu um grande e importante campo de atuação institucional para conferir ao MP mecanismos para promover os valores sociais constitucionais.

Esse autor entende que, por meio dessa função, foi atribuída ao MP a função de velar pela atuação dos órgãos da Administração Pública, dentro dos princípios constitucionais determinados, cobrindo a insuficiência de controles que fazia necessário o surgimento de um órgão que se encarregasse do controle residual.

No mesmo sentido Milaré (2009), para quem a causa da inovação legislativa a favor do fortalecimento do MP foi o descompasso havido a partir da década de 1980, com o surgimento do movimento ambientalista no Brasil e a incapacidade do Estado de responder a essa mudança com uma mobilização de recursos humanos e materiais para melhor estruturação dos órgãos fiscalizadores, incumbindo-se o MP de promover o poder coercitivo das normas ambientais.

\footnotetext{
${ }^{127}$ Lei Federal 6.938/81, artigo 14, § $1^{\circ}$ : "Sem obstar a aplicação das penalidades previstas neste artigo, é o poluidor obrigado, independentemente da existência de culpa, a indenizar ou reparar os danos causados ao meio ambiente e a terceiros, afetados por sua atividade. O Ministério Público da União e dos Estados terá legitimidade para propor ação de responsabilidade civil e criminal, por danos causados ao meio ambiente" (BRASIL, 1981).

${ }^{128}$ Lei Federal 7.347/85 (BRASIL, 1985).

${ }^{129}$ Lei Federal 7.347/85, artigo 5, III, "d" (BRASIL, 1985).

${ }^{130}$ É o caso da Lei Orgânica Nacional do Ministério Público, Lei Complementar Federal 8.625/93 (BRASIL, 1993) e, especificamente no Estado de São Paulo, a Lei Orgânica Estadual do Ministério Público, Lei Complementar Estadual-SP 734/93 (SÃO PAULO, 1993).
} 
O MP pode, ainda, requisitar a instauração de sindicâncias administrativas e inquéritos policiais, assim como ajuizar ações de improbidade ${ }^{131}$ em face do agente público que conduz o processo de licenciamento ambiental, em casos que entenda haver desvio de conduta.

Com esse arsenal de instrumentos, o MP brasileiro é uma instituição na fiscalização de processos de licenciamento ambiental, contando com um poder coercitivo significativo dentro e fora do processo administrativo, sem similares no ordenamento nacional. E desta forma, conforme ressaltado por Milaré (2009, p. 1.154), o MP se firmou como

a instituição mais bem credenciada para a tutela dos interesses sociais, difusos e coletivos, na ordem civil. Isso sem prejuízo de sua tradicional atuação na área criminal, inclusive na repressão aos chamados crimes ecológicos.

Vistos os princípios institucionais, a estrutura, os instrumentos e as atribuições do MP, passaremos a analisar especificamente a atuação do MP no licenciamento ambiental.

\footnotetext{
131 A ação de improbidade administrativa é regulada pela Lei Federal 8.429/92, consistindo em um tipo de ação que visa a apurar e punir a prática de ilícitos na administração pública direta e indireta, além de recuperar os prejuízos em favor dos cofres públicos. Conforme lembra Grinover (2005, p. 16), "é uma verdadeira ação popular (destinada à proteção do interesse público e não à defesa de interesses e direitos de grupos, categorias e classes de pessoas), com legitimação conferida por lei ao MP. Esta legitimação encontra embasamento no art. 129, IX, da CF-88. Aqui também a lei de regência será a Lei 8.429/22, aplicando-se à espécie as disposições do Capítulo I do Código". Isso porque qualquer cidadão poderá representar às autoridades competentes. Porém, merece ser ressaltado que não se trata de iniciativa privativa do MP, podendo este ser parte ou fiscal da lei.
} 


\section{MECANISMOS DE CONTROLE DO LICENCIAMENTO AMBIENTAL E DO ESTUDO DE IMPACTO AMBIENTAL}

Conforme analisado no item 3.1, o licenciamento ambiental de empreendimentos de significativo impacto ambiental requer EIA e, tanto um quanto outro, devem obedecer a diretrizes legais e são constituídos de aspectos técnicos e de participação popular.

Se cabe discricionariedade à Administração Pública para exigir o EIA em situações não expressas na legislação, Milaré e Benjamin (1993) ressaltam que o mesmo não ocorre na situação inversa: a dispensa desse estudo nos casos expressamente exigidos pela legislação caracteriza-se uma irregularidade.

De forma análoga, o órgão ambiental pode exigir licenciamento ambiental para empreendimentos que não constam nos regulamentos como sujeitos a esse procedimento, mas não pode dispensar para aqueles que estão relacionados em tais regulamentos.

Conforme Salles (2009), o MPE-SP é bastante atuante para cobrar a elaboração de EIA nos casos em que este estudo tenha sido dispensado, assim como nos casos em que as condicionantes previstas nas licenças ambientais não foram cumpridas (informação verbal) ${ }^{132}$.

Para a exigibilidade do licenciamento ambiental, basta que se tratem de atividades ou projetos potencial ou efetivamente poluidores e utilizadores de recursos naturais ${ }^{133}$.

132 Informação fornecida por Salles em entrevista pessoal realizada em 08.10.2009. Referências sobre o entrevistado constam do Anexo 6.

${ }^{133}$ Política Nacional de Meio Ambiente (Lei Federal 6.938/81), artigo 10: “A construção, instalação, ampliação e funcionamento de estabelecimentos e atividades utilizadoras de recursos ambientais, considerados efetiva e 
Conforme Milaré e Benjamin (1993), a dispensa irregular de EIA pode ser questionada na esfera administrativa (perante a autoridade administrativa ambiental responsável pelo ato praticado ou seu superior hierárquico) e na judicial (levando-se a questão ao Poder Judiciário por meio de ação civil pública ou ação popular).

Mesmo tendo sido exigido e elaborado, o EIA-RIMA pode ser impugnado administrativa ou judicialmente, tanto por vícios materiais (conteúdo inadequado) quanto formais (não realização de audiência pública), caso se avente alguma irregularidade na sua execução.

Tanto que diversas ações civis públicas foram propostas entre 1981 a março de 1992 em face do Poder Público que, ao construir estradas, hidrelétricas e outras obras, deixou de realizar o EIA-RIMA ou o fez de maneira inadequada (MILARÉ; BENJAMIN, 1993).

Esses autores destacam que a tendência seria a de impor amarras ao administrador para evitar o mau uso da discricionariedade que o legislador lhe conferiu.

Di Pietro (2003) confirma a tendência de, no direito brasileiro, buscar-se limitar cada vez mais a discricionariedade administrativa, de modo a ampliar o controle judicial.

potencialmente poluidores, bem como os capazes, sob qualquer forma, de causar degradação ambiental, dependerão de prévio licenciamento de órgão estadual competente, integrante do Sistema Nacional do Meio Ambiente e do Instituto Brasileiro do Meio Ambiente e Recursos Naturais Renováveis, em caráter supletivo, sem prejuízo de outras licenças exigíveis" (BRASIL, 1981). A Resolução Conama 237/97 (CONAMA, 1997), regulamentando a Política Nacional de Meio Ambiente, traz a mesma disposição, prevendo a competência do órgão ambiental a quem caberia definir os estudos ambientais pertinentes ao respectivo processo de licenciamento, bem como diretivas mais detalhadas sobre a condução do licenciamento. 
Não obstante, essa autora alerta para o fato de que o controle judicial dos atos discricionários deverá respeitar o espaço para livre decisão que a lei tiver assegurado à Administração Pública, não podendo o Poder Judiciário invadir esse espaço pois, caso contrário, estaria substituindo por seus próprios critérios de escolha, a opção legítima feita pela autoridade competente com base em razões de oportunidade e conveniência que ela está mais capacitada - e por que não dizer, também legitimada - para decidir diante de cada caso concreto.

Além do que, no caso prático, como coloca Fink, Dawalibi e Alonso (2002), não há como eliminar o aspecto discricionário da Administração Pública no processo de licenciamento ambiental, por haver uma margem de liberdade para a escolha da alternativa mais vantajosa entre as que se figuram como legítimas.

Para coibir ou penalizar ilicitudes decorrentes do mau uso da discricionariedade, além de outras irregularidades, há instrumentos jurídicos que podem ser acionados. Daí a chamada judicialização do licenciamento ambiental, ou seja, a transposição de sua discussão da esfera administrativa para a esfera judicial.

Moraes (2005) coloca-se favorável a essa intervenção por entender que a sua causa consiste nas limitações do licenciamento ambiental e do EIA, como a baixa qualidade dos estudos apresentados, a dubiedade do papel das audiências públicas, a insegurança quanto ao papel do órgão ambiental licenciador (imparcialidade em contraposição à defesa de interesses políticos setorizados), a burocracia exagerada, morosidade e os altos custos. 
Também Bugalho (2005) defende a judicialização por esta ser parte das medidas de precaução para prever, evitar ou minimizar as causas que possam comprometer a qualidade ambiental, especialmente quando existirem ameaças de danos sérios e irreversíveis e que a adoção de providência judicial ou extrajudicial visando à implementação de medidas para impedir ou paralisar a atividade nociva, ou a reparação do dano ambiental, também é tarefa constitucionalmente atribuída ao MP.

Antunes (2007) pondera que, como o licenciamento ambiental é um processo muito mais técnico do que jurídico, o controle de legalidade se torna muito complexo, tendo, de um lado, a presunção de legalidade dos atos administrativos (entre os quais incluem-se a emissão de licenças ambientais ou mesmo as decisões administrativas de dispensa de licença), como uma das bases do Estado Democrático de Direito e sua segurança jurídica, e, de outro, a crise de credibilidade das agências de controle ambiental, cumulada com uma crise geral de credibilidade da instituição pública no Brasil.

Nesse contexto, esse autor aponta que a judicialização mostra-se uma importante ferramenta dos cidadãos contra desmandos de muitos administradores que agem com desvio de poder ou abuso de autoridade, mas destaca a importância de se prestigiar as ações administrativas dos órgãos ambientais para que eles possam desempenhar os seus papéis de forma mais segura e abrangente, sem o que surgem reflexos sobre o setor elétrico nas diversas esferas.

Reforça esse alerta Agra Filho (2008), que atribui ao MP uma parcela de contribuição pela precariedade dos Conselhos de Meio Ambiente por conta da crescente participação e pelas crescentes demandas sobre as licenças ambientais. 
Sobre o assunto, Fontes (2005) destaca que a legislação brasileira prevê instrumentos nãojurisdicionais que podem ser melhor aproveitados pelo MP. Exemplo disso são as recomendações que a instituição pode dirigir aos entes públicos ${ }^{134}$ que, no seu entender, no mais das vezes estariam sendo utilizadas dentro da lógica jurisdicional, simplesmente com o objetivo de evitar o ajuizamento de ações; ou seja, os membros do MP só estariam recomendando aquilo que consideram possível de obter na Justiça, de maneira coercitiva.

$\mathrm{Na}$ defesa do meio ambiente, esse autor reconhece que, a atuação do MP acaba sendo um controle da legalidade dos atos e omissões da Administração, podendo contribuir para que a Administração Pública observe a exigência legal da realização de procedimentos dotados de discricionariedade, tais como o processo de licenciamento e a avaliação dos estudos ambientais, e desta forma contribuir para o aperfeiçoamento desses instrumentos.

De qualquer forma, Fontes (2005, p. 152) sugere ao MP "melhorar a qualidade do seu relacionamento com os Poderes Executivo e Legislativo" e ressalta que

a Administração deve ser antes vista como parceira, à qual é preciso trazer a visão de um agente próximo à população e mais imune à lógica burocrática. Seria um erro ser sistematicamente contra a Administração; a posição vantajosa do ombudsman para propor reformas consiste justamente em estar fora do sistema mas, ao mesmo tempo dentro, buscando com freqüência as mesmas finalidades e compartilhando os mesmos valores das agências governamentais.

É o que defende Goldemberg (2009), para quem a competência para conduzir o licenciamento ambiental foi conferida à Administração; assim, o MP pode levantar dúvidas e fazer questionamentos, mas não pode desacreditar o órgão ambiental ${ }^{135}$.

\footnotetext{
${ }^{134}$ Previsto no artigo 27 da Lei Orgânica dos MPs dos Estados (Lei Federal 8.625/93) e no artigo 6 ${ }^{\circ}$, XX, da Lei Orgânica do MP da União (Lei Complementar Federal 75/93).

${ }_{135}$ Informações fornecidas por Goldemberg em entrevista realizada em 17.12.2008. Referências sobre o entrevistado constam do Anexo 6.
} 
Uma de suas principais críticas à atuação do MP no processo licenciamento é o fato de que, em sua experiência como Secretário do Meio Ambiente, ter verificado, por vezes, que o MPESP parece competir com o órgão ambiental. Ao questionar passo a passo o processo de licenciamento ambiental, o MP viola a autoridade do Secretário para conduzir o licenciamento, para presidir o Consema e para emitir a licença ambiental, tirando a legitimidade que a legislação conferiu ao órgão ambiental.

E quando o MP impede, por meio de medidas liminares, a realização de audiências públicas ou de plenários no Consema, está impedindo o órgão do Executivo de exercer suas funções, o que é um contra-senso.

Ele alerta também que, para seguir o que está previsto na legislação ambiental, é necessário conhecimento técnico e por isso existe a Cetesb. No entanto, enquanto esteve à frente da SMA, percebeu que há grupos contrários a determinados projetos por razões ideológicas, políticas ou quaisquer outras que não relacionadas com as técnicas, que instrumentaram o MP com argumentos contrários e até com estudos técnicos de baixa qualidade.

Um caso de que se lembra bem foi relacionado a um projeto no Porto de Santos, quando o MPE-SP apresentou um laudo de um instituto desconhecido de Porto Alegre / RS, com base no qual aquela instituição questionou os estudos analisados pela SMA - Cetesb.

Na mesma linha, Rei (2008) lamenta a ingerência do MP dissociado da vocação de equacionador público, propiciando uma situação de insegurança jurídica ao fazer com que o empreendedor busque o MP para ter certeza sobre o resultado de seu licenciamento. 
A seu ver, a fiscalização exercida pelo MPE-SP não pode se constituir em um segundo licenciamento, o que seria uma falta de respeito ao dinheiro do contribuinte que paga para a Administração Pública realizar esse trabalho para o qual é legitimada ${ }^{136}$.

Ele defende também que a relação entre o MP e o órgão ambiental deva ser horizontal, de parceria, cada qual em sua esfera de atribuição de competências. Pela sua avaliação, quanto mais experiente o promotor ou o procurador de justiça, mais ele valoriza o diálogo com o órgão ambiental e a busca do equacionamento, porque percebe que essa postura levará a resultados melhores e mais rápidos para o meio ambiente, ao invés de apenas visar à responsabilização, à imposição de sanção.

Por fim, merecem algumas reflexões a formação técnica dos profissionais que analisam e discutem o licenciamento ambiental e o EIA.

No caso específico da SMA e da Cetesb, os agentes públicos são predominantemente constituídos por profissionais concursados ou contratados, havendo um certo número de comissionados (cargo de confiança), especialmente nos cargos gerenciais.

Sendo funcionários públicos, são sujeitos às vedações impostas ao funcionalismo de forma geral e às eventuais retaliações por meio de sindicâncias administrativas ou ações de improbidade administrativa.

\footnotetext{
${ }^{136}$ Informações fornecidas por Rei em entrevista realizada em 16.12.2008. Referências sobre o entrevistado constam do Anexo 6.
} 
Em contraposição, como os membros do MP têm formação jurídica (com base na qual são $\operatorname{concursados}^{137}$ ), o seu apoio técnico é dado fundamentalmente pelos assistentes técnicos da Promotoria. Estes não se enquadram nas disposições aplicáveis aos membros do MP quanto a cargos e provimentos, sendo profissionais de formação técnica que são convidados pelo Procurador Geral de Justiça para ocupar cargos de confiança com o fim de fornecer os subsídios técnicos aos membros do MP.

São cerca de quinze assistentes técnicos para atender a todos os promotores ocupantes de cargos nas promotorias de justiça de meio ambiente ${ }^{138}$ no Estado de São Paulo.

Embora haja profissionais de diferentes formações (geólogo, engenheiro florestal, engenheiro agrônomo, entre outros), devido ao número restrito de assistentes técnicos e o grande número de demandas, na prática, dificilmente haverá uma multidisciplinaridade de técnicos do MP para avaliar um determinado projeto.

O MPE-SP ainda tem a possibilidade de contar com o apoio técnico das universidades: o MPE-SP tem convênio com universidades em Presidente Prudente e em Ribeirão Preto, firmados entre o Procurador Geral de Justiça e os Reitores dessas Universidades.

\footnotetext{
${ }^{137}$ Conforme previsto na Constituição Federal e regulamentado na legislação esparsa, os membros do Ministério Público têm acesso aos cargos por concurso público de provas ou de provas e títulos (CF-88, artigo $127,2^{\circ}$ ) (BRASIL, 1988).

${ }^{138}$ Conforme informações obtidas junto ao CAO-UMA e confirmadas por Fink (2009) e Salles (2009) em entrevistas realizadas, respectivamente, em 10.08.2009 e 08.10.2009. Referências sobre os entrevistados constam do Anexo 6.
} 
Pelo modelo adotado, os alunos fazem o trabalho de campo como parte de sua formação prática, sob a supervisão de um professor doutor. O MPE-SP não remunera pelos serviços nem reembolsa as despesas incorridas, sendo que a motivação para os pesquisadores é a possibilidade de adquirir experiência prática em casos muitas vezes controversos.

Embora seja um modelo bastante interessante, Fink (2009) pondera que essa contribuição é ainda secundária em relação à dos assistentes técnicos da Promotoria, pelo fato de poucas comarcas estarem contempladas pela atuação dessas universidades conveniadas e pelo fato de alguns projetos envolverem custos elevados para os alunos em termos de despesas de locomoção, equipamentos e outros insumos necessários para o trabalho a ser realizado, e o MPE-SP não ter verbas destinadas ao seu reembolso. Ele destaca ainda o fato de muitos professores universitários exercerem paralelamente a atividade de consultores, ensejando questionamento sobre eventual conflito de interesses (informações verbais) ${ }^{139}$.

Uma terceira fonte de bases técnicas para o MPE-SP são laudos provenientes de outras instituições que sejam consideradas independentes.

Para o exercício da função de zelar pela correta atuação da Administração Pública no licenciamento ambiental, Fontes (2005) destaca que a sua credibilidade e poder de persuasão advêm de sua capacidade técnica, sendo indispensável ao MP na medida em que ele atue dentro de um ponto de vista menos jurisdicional.

\footnotetext{
${ }^{139}$ Informações fornecidas por Fink (2009) em entrevistas realizada 10.08.2009. Referências ao entrevistado constam do Anexo 6.
} 
Daí ele conclui que a capacitação de membros da instituição, bem como a existência de recursos humanos e materiais suficientes, constituem condição da eficácia da instituição na defesa dos interesses difusos e coletivos.

Concordam com essa assertiva, Rei (2008) e Mondelo (2008), para quem a participação do MP nas discussões relativas ao licenciamento é importante, assim uma assessoria técnica mais ampla permitiria que os membros do MPE-SP pudessem atuar de forma mais eficiente para a fiscalização do licenciamento ambiental conduzido pela SMA (informações verbais) ${ }^{140}$.

O problema é quando ocorrem divergências técnicas entre a SMA e o MPE-SP. Daí surgem conflitos entre esses órgão, cuja solução é complexa.

Para Rei (2008), deveria haver uma tentativa de entendimento entre os técnicos do MP e órgão ambiental para identificar inconsistências. E em permanecendo o embate, deveria prevalecer o entendimento daquele tem poder de polícia e de fiscalização sobre o meio ambiente, ou seja, o do órgão ambiental, não o do MPE-SP ${ }^{141}$ (informações verbais).

Também é esse o entendimento de Goldemberg (2008), para quem a avaliação feita pela Administração Pública deve prevalecer por conta de sua legitimidade para a realização desse trabalho $^{142}$ (informações verbais).

\footnotetext{
${ }^{140}$ Informações fornecidas por Rei (2008) e Mondelo (2009) em entrevistas realizadas, respectivamente, em 16.12.2008 e em 07.01.2009. Referências sobre os entrevistados constam do Anexo 6.

${ }^{141}$ Informações fornecidas por Rei (2008) em entrevista realizada em 16.12.2008. Referências sobre o entrevistado constam do Anexo 6.

${ }^{142}$ Informações fornecidas por Goldemberg (2008) em entrevista realizada em 17.12.2008. Referências sobre o entrevistado constam do Anexo 6.
} 
Pelo lado do MPE-SP, Fink (2009), havendo conflito de entendimento técnico entre os órgãos licenciadores e o assistente do MP, o promotor prestigiará a opinião de seu assistente técnico de confiança. Ao comentar essa postura, Fink (2009) faz analogia entre o juiz e seu perito judicial: assim como o juiz confia em seu perito judicial, o promotor confiará em seu técnico (informações verbais) $^{143}$.

Não é diferente o entendimento de Salles (2009). A seu ver, como o questionamento do MPESP sobre algum aspecto do licenciamento ambiental de determinado projeto surge em função de dúvida a respeito da condução feita pelo órgão ambiental, não teria como fazer prevalecer o entendimento daquele corpo técnico (informações verbais) ${ }^{144}$.

Como sugestão para minimizar a situação de insegurança jurídica decorrente da judicialização do processo de licenciamento ambiental, Rei (2008) sugere que a decisão do Consema vincule o posicionamento da instituição MPE-SP, de forma que um projeto aprovado pelo Consema não seja questionado posteriormente pelo promotor local (informações verbais) ${ }^{145}$.

Ou seja, ele propõe que haja uma convergência entre a orientação de cúpula do MP e seus membros. O que favoreceria a uma atuação institucional ao invés de pessoal, conforme se verifica atualmente, quando a atuação de cada promotor acaba sendo personalíssima.

\footnotetext{
${ }^{143}$ Informações fornecidas por Fink em entrevista realizada em 10.08.2009. Referências sobre o entrevistado constam do Anexo 6.

144 Informações fornecidas por Salles (2009) em entrevista realizada em 08.10.2008. Referências sobre o entrevistado constam do Anexo 6.

${ }^{145}$ Informações fornecidas por Rei (2008) em entrevista realizada em 16.12.2008. Referências sobre o entrevistado constam do Anexo 6. Nessa ocasião, o entrevistado comentou ainda que, tamanha é a independência dos membros do MPE-SP que hoje há casos de promotores novos em algumas comarcas que estão ajuizando ação de responsabilidade em face de antigos promotores que firmaram TACs homologados pelo Conselho Superior do Ministério Público.
} 
Pela estrutura atual, mesmo que um projeto tenha sua viabilidade ambiental aprovada pelo Consema, com a presença do representante do MPE-SP no exercício de seu papel de conselheiro, o representante do MPE-SP da comarca local poderá questionar aspectos técnicos e jurídicos desse procedimento, por conta do princípio da autonomia do MP.

É, por exemplo, o que ocorreu no caso estudado em profundidade no item 6 (a UTE Santa Branca), que teve sua viabilidade ambiental aprovada pelo plenário do Consema, que por sua vez acolheu as emendas técnicas propostas pelo membro do MPE-SP naquele conselho, mas que ao final teve sua licença cancelada por atuação do promotor local.

Para Salles (2009) ${ }^{146}$, poderia haver uma integração maior entre o CAO e as Promotorias de Meio Ambiente, o que talvez favorecesse uma unificação nas ações tomadas pelo MPE-SP no licenciamento ambiental (informações verbais). 146 Informação fornecida por Salles em entrevista pessoal realizada em 08.10.2009. Referências sobre o
entrevistado constam do Anexo 6 . 


\section{COLETA DE DADOS}

\subsection{DAdos de LiCEnCIAMENTo AMbiental DE EMPREENdimentos DE GERAÇÃo DE energia - Secretaria de Meio Ambiente do Estado de São Paulo}

Conforme analisado no item 3, o licenciamento ambiental de empreendimentos de geração de energia na SMA inicia-se no DAIA. Assim, para efeito deste estudo, em primeiro lugar foi feito o levantamento de empreendimentos relacionados à geração de energia elétrica analisados pelo DAIA entre 1997 e 2006 junto a esse Departamento (2007).

O levantamento foi realizado a partir de 1997 para permitir abarcar os dados de entrada dos empreendimentos que se encontrassem em processo de licenciamento no período correspondente ao recorte temporal adotado, uma vez que, entre o pedido inicial e o deferimento (ou não) da licença ambiental, podem-se transcorrer alguns anos.

Nesse período, verifica-se que, no total, o DAIA avaliou 215 pedidos relacionados a projetos de geração de energia elétrica ${ }^{147}$, dos quais 97 consistem em consultas ${ }^{148}, 15$ em Relatórios de Regularização Ambiental (RRA), 9 referem-se a planos de trabalho e 1 a regulamentação expedida pelo Gabinete da SMA tratando de pequenas centrais hidrelétrica (PCHs), 4 foram pedidos de licença de instalação ou de operação de projetos existentes.

\footnotetext{
147 Ressalva-se que os 215 pedidos referem-se a processos administrativos abertos no DAIA, não correspondendo necessariamente a 215 empreendimentos.

148 Conforme Resolução SMA 54/2004, "Não havendo clareza acerca da magnitude e da significância dos impactos ambientais decorrentes da implantação de empreendimento ou atividade, o empreendedor deverá protocolizar Consulta Prévia na SMA/DAIA, com vistas à definição do tipo de estudo que deverá iniciar os procedimentos para o licenciamento".
} 
Os 89 restantes tratam diretamente de pedidos de licenciamento ambiental protocolados no DAIA entre 1997 e 2006. Desses, 73 pedidos foram protocolados com a apresentação de Relatório Ambiental Preliminar (RAP) e 16 com EIA-RIMA.

Para facilitar a visualização, tabulamos esses dados no gráfico abaixo:

\section{Pedidos protocolados no DAIA por Categoria}

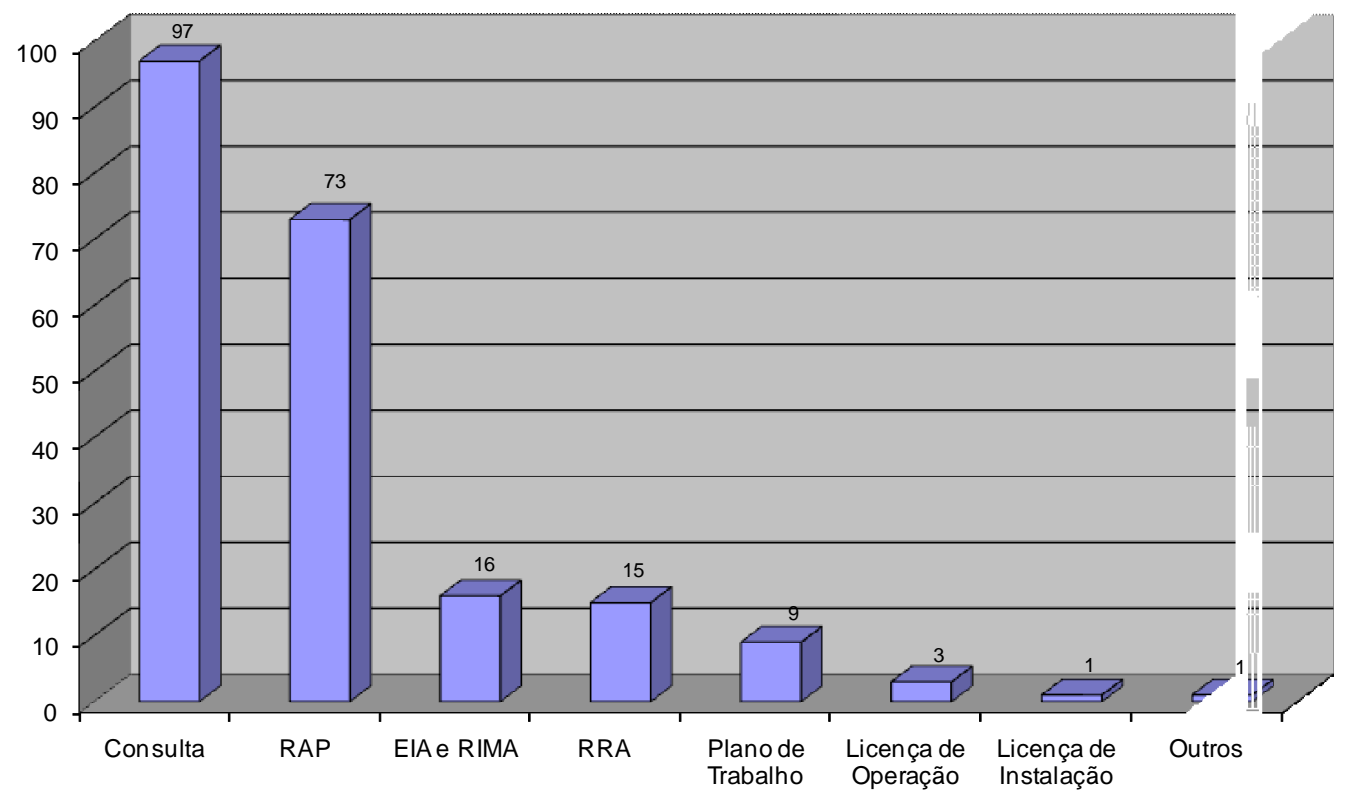

Figura 4 - Pedidos protocolados entre 1997-2006 no DAIA classificados por categoria (fonte: DAIA, 2007)

Sob outro critério de análise dos dados levantados, tem-se também que, dos 215 pedidos relacionados a geração de energia elétrica analisados pelo DAIA nesse período, 98 projetos estavam relacionados à matriz termoelétrica, incluindo-se termelétricas utilizadoras de matriz fóssil e projetos de cogeração. A maioria, totalizando 117, eram projetos baseados em matriz hidroelétrica, entre UHEs e PCHs. 


\section{Pedidos classificados pela matriz energética}

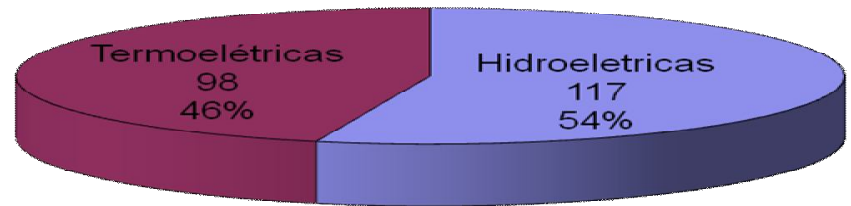

Figura 5 - Pedidos protocolados entre 1997-2006 no DAIA classificados por matriz energética (fonte: DAIA, 2007)

Verifica-se também que os anos em que houve maior número de pedidos protocolados naquele departamento relacionado a empreendimentos de geração de energia elétrica, foram 1999, 2001 e 2002, sendo que em 2005 e 2006 os índices voltaram aos patamares anteriores a 1999, conforme pode ser verificado no gráfico abaixo:

Pedidos protocolados no DAIA por Ano

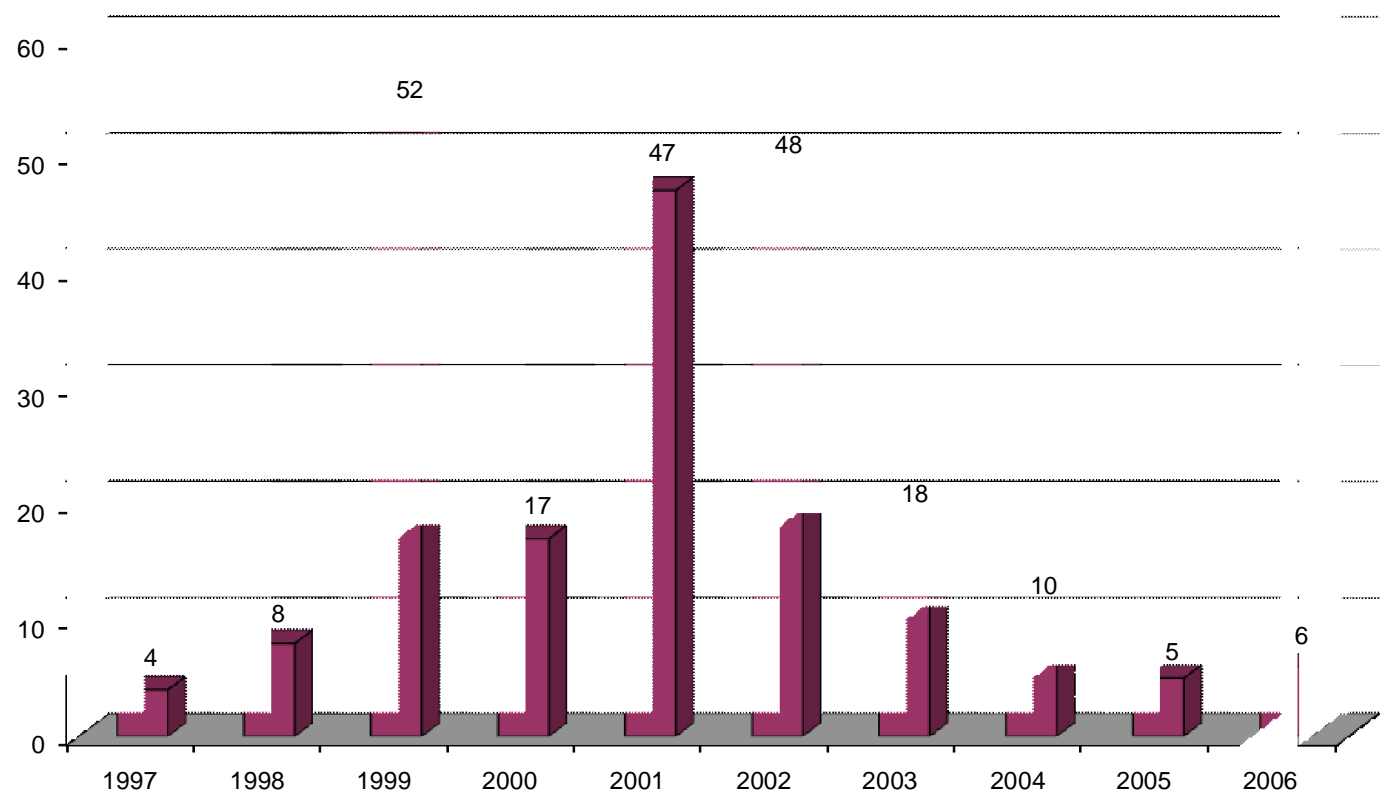

Figura 6 - Pedidos protocolados entre 1997-2006 no DAIA classificados pelo ano de abertura dos processos administrativos (fonte: DAIA, 2007) 
Feitos os levantamentos no DAIA, procuramos rastrear os processos internamente na SMA para identificar eventuais intervenções do MP no decorrer do processo de licenciamento, indo em seguida para o levantamento de dados no Consema.

Com base na análise das Deliberações e Moções expedidas pelo Consema no período estudado, verifica-se que esse conselho discutiu e aprovou a viabilidade ambiental de um projeto de geração de energia elétrica pela primeira vez em 2001.

Foram discutidos e aprovados pelo plenário do Consema, no período de 2001 a 2006, os seguintes projetos:

\begin{tabular}{|l|l|}
\hline \multicolumn{1}{|c|}{ Nome do projeto } & \multicolumn{1}{c|}{ Deliberação Consema que o aprovou } \\
\hline $\begin{array}{l}\text { UTE Central de Cogeração da } \\
\text { Baixada Santista - CCBS }\end{array}$ & Deliberação Consema 01/2001, de 29.01.2001 \\
\hline UTE Cogeração Capuava & Deliberação Consema 28/2001, de 16.10 .2001 \\
\hline UTE Duke 1 & Deliberação Consema 33/2001, de 27.11.2001 \\
\hline UTE Carioba II & Deliberação Consema 06/2002, de 20.03.2002 \\
\hline UTE Santa Branca & Deliberação Consema 01/2002, de 21.01.2002 \\
\hline UTE Araraquara & Deliberação Consema 05/2005, de 22.02.2005 \\
\hline UTE Piratininga 2 & Deliberação Consema 24/2005, de 08.06.2005 \\
\hline UTE Pioneiros Bioenergia & Deliberação Consema 46/2006, de 04.12.2006 \\
\hline
\end{tabular}

Dos empreendimentos cuja viabilidade ambiental foi aprovada, verificou-se a existência de duas licenças concedidas e cassadas no curso do processo de licenciamento ambiental: a da UTE Santa Branca e a da UTE Carioba II. 
Na Consultoria Jurídica da SMA e no Departamento Jurídico da Cetesb não foram disponibilizados registros sobre a judicialização de processos de licenciamento ambiental ou eventuais intervenções do MPE-SP sobre os mesmos. A justificativa para a ausência dessas informações seria o fato de esses departamentos jurídicos não acompanharem os processos judiciais, tarefa que fica a cargo de outro órgão da Procuradoria Geral do Estado ${ }^{149}$.

Como a SMA não tem personalidade jurídica, ela é representada em juízo pela Fazenda Pública do Estado de São Paulo, tendo como agentes atuantes na esfera judicial, os procuradores do Estado lotados na Procuradoria do Patrimônio Imobiliário ${ }^{150}$. Dentro dessa Procuradoria, há uma $1^{\text {a }}$ Subprocuradoria do Contencioso Ambiental, responsável pelas ações judiciais nas quais o Estado esteja envolvido no tocante a questões ambientais.

Nessa Subprocuradoria, também não foram disponibilizados bancos de dados que permitissem rastrear os processos de licenciamento ambiental que tivessem sido objeto de litígio. A justificativa para essa ausência de informações seria devida a (i) falta de informatização da Procuradoria do Patrimônio Imobiliário, que não cadastra as ações sob seus cuidados; e (ii) pelo sistema de distribuição das causas entre os procuradores, baseado na numeração dos processos (número final de cada processo) e não pelos assuntos ou pelos tipos de ações ${ }^{151}$.

\footnotetext{
${ }^{149}$ Lembrando que os procuradores alocados na SMA fazem parte da Procuradoria Geral do Estado, não da SMA. No caso da Cetesb, há procuradores autárquicos, mas que não são envolvidos nas ações judiciais em face da Fazenda Pública, a qual representa a SMA em juízo.

150 Conforme Lei Complementar Estadual 478/86 (Lei Orgânica da Procuradoria Geral do Estado), são atribuições da Procuradoria do Patrimônio Imobiliário representar a Fazenda do Estado em processos ou ações de qualquer natureza, cujo objeto principal, incidente ou acessório, verse sobre direitos reais ou possessórios, patrimônio imobiliário e águas do domínio do Estado (artigo 19, inciso I, alínea "a").

${ }^{151}$ Informações verbais fornecidas por Costa (2009), procurador do Estado lotado na $1^{\text {a }}$ Subprocuradoria do Contencioso Ambiental da Procuradoria do Patrimônio Imobiliário, em entrevista realizada em 22.10.2009. Referências sobre o entrevistado constam do Anexo 6.
} 
Não obstante as lacunas nas informações, o que se verificou é que, na percepção de membros do MPE-SP e da Procuradoria do Patrimônio Imobiliário, há uma grande quantidade de ações propostas pelo MPE-SP discutindo aspectos do licenciamento ambiental conduzido pela SMA. Embora seja controverso tentar definir uma tendência sobre êxitos no Judiciário.

Se por um lado Fink (2009), como membro do MPE-SP, indica que as ações propostas por essa instituição são muitas vezes julgadas procedentes, por outro lado Costa (2009), como representante do Estado, informa que da grande quantidade de ações propostas pelo MPE-SP e por organizações não governamentais (ONGs) para questionar o processo de licenciamento da SMA, são muitas as ações julgadas improcedentes ${ }^{152}$ (informações verbais).

Já Salles (2009), também membro do MPE-SP, pondera que há vezes em que as ações propostas pelo MPE-SP têm decisão favorável ao pleito da instituição, mas também há outras vezes em que os resultados lhe são desfavoráveis (informações verbais) ${ }^{153}$.

\subsection{DESCRIÇÃO DO PROJETO DA UTE SANTA BRANCA}

O empreendimento em estudo é a UTE Santa Branca, proposto pela empresa Eletroger Ltda. para ser implantado no Município de Santa Branca, inserido na Bacia e Sub-bacia Hidrográfica de Paraíba do Sul, no Vale do Paraíba, Estado de São Paulo.

\footnotetext{
152 Informações verbais fornecidas por Fink (2009) e Costa (2009) em entrevistas realizadas, respectivamente, em 10.08.2009 e 22.10.2009. Referências sobre os entrevistados constam do Anexo 6.

${ }^{153}$ Informações verbais fornecidas por Salles (2009) em entrevista realizada em 08.10.2009. Referências sobre o entrevistado constam do Anexo 6.
} 
A Eletroger Ltda. era uma sociedade em conta de participação constituída pela Eletropaulo Metropolitana Eletricidade de São Paulo S.A., empresa pública posteriormente privatizada para a concessionária AES Eletropaulo - AES Tietê.

A UTE Santa Branca estava incluída como empreendimento prioritário e foi autorizada pela ANEEL a estabelecer-se como produtor independente de energia elétrica, mediante a implantação da central geradora termelétrica Santa Branca com potência instalada de 1.112.480 kW, no Município de Santa Branca, Estado de São Paulo ${ }^{154}$.

Pela descrição do projeto aprovado pela ANEEL, a central geradora seria constituída de seis turbogeradoras, agrupadas em dois blocos iguais em ciclo combinado ${ }^{155}$ multi-eixo de duas unidades a gás para uma a vapor, denominados Bloco I e Bloco II.

Entre outras obrigações, a ANEEL estabeleceu os seguintes prazos: (a) obter licença prévia até 31.12.2001; (b) obter licença de instalação até 31.01.2002; (c) iniciar a implantação do canteiro de obras até 28.02.2002; (d) iniciar as obras civis das estruturas até 30.04.2002; (e) iniciar a montagem eletromecânica até 31.10.2002; (f) iniciar o comissionamento das turbogeradoras entre 31.05.2003 e 30.09.2003; (g) obter licença de operação até 31.07.2003 para o Bloco I e até 30.09.2003 para o Bloco II; e (h) iniciar a operação comercial com quatro turbogeradoras a gás do Bloco I até 31.07.2003, do Bloco II até 30.09.2003 e duas turbogeradoras a vapor do Bloco I até 31.12.200 e do Bloco II até 28.02.2004.

\footnotetext{
${ }^{154}$ Em conformidade com o Decreto 3.371, de 24.02.2000, a Portaria MME 43, de 26.02.2000 e a Resolução ANEEL 664/01.

${ }^{155}$ Conforme explanado nos estudos ambientais que subsidiaram o licenciamento ambiental, o ciclo combinado consiste no seguinte processo: a alta temperatura dos gases de exaustão de turbinas a gás será aproveitada em um caldeirão de recuperação para gerar vapor, que por sua vez é utilizado nas turbinas a vapor, gerando energia elétrica a partir do calor.
} 
Também a Eletroger Ltda. apresentou o cronograma esperado prevendo que a construção da UTE Santa Branca se iniciaria em 2001 e terminaria no final de 2002, com a entrada em operação no final de 2002/início de 2003.

Considerando-se a complexidade dos estudos exigidos no licenciamento ambiental de empreendimentos desse porte, a multiplicidade de etapas desse processo (envolvendo audiências públicas e discussões pelo Consema, fora a avaliação técnica), além do prazo usualmente praticado pelos órgãos licenciadores para a emissão de licenças ambientais, os prazos previstos pela ANEEL e pelo empreendedor como meta eram ambiciosos.

Pelos dados divulgados pela Empresa, o custo estimado do empreendimento seria de US\$600 milhões. A energia nele gerada seria fornecida principalmente no Vale do Paraíba, na Grande São Paulo e na região Sudeste.

Conforme estudos ambientais apresentados pela Eletroger Ltda. ao DAIA e avaliados por este departamento, o projeto consistiria na implantação de 4 turbogeradores a vapor, em duas fases, denominadas bloco de força A e B, com potência líquida total de 960 MW, devendo ocupar uma área de aproximadamente $100.000 \mathrm{~m} 2$. Portanto, há algumas diferenças entre a proposta apresentada à SMA e a aprovada pela ANEEL.

Entre os principais impactos socioambientais identificados nos estudos ambientais apresentados pelo empreendedor destacam-se: (i) aumento do uso das águas, contraposta à limitação de recursos hídricos da região; (ii) geração de efluentes líquidos; e (iii) emissões gasosas significativas em local com capacidade limitada de dispersão atmosférica. 
Desta forma, os principais impactos ambientais que seriam causados estavam relacionados a alterações na qualidade das águas e do ar.

Como contrapartida, o empreendedor destacou os benefícios que decorreriam da UTE Santa Branca: aumento nos investimentos na região pelo incremento e segurança no fornecimento de energia elétrica, criação de empregos (750 empregos temporários durante a construção e 50 permanentes na operação) e aumento na participação do município de Santa Branca no rateio de Imposto sobre Circulação de Mercadorias e Prestação de Serviços - ICMS.

O gás natural seria fornecido pela Companhia de Gás de São Paulo - COMGÁS por extensão do Gasoduto Brasil-Bolívia - GASBOL, sendo ainda prevista uma linha de transmissão de 7 quilômetros, com potência de $550 \mathrm{kV}$.

O suprimento de água do sistema de resfriamento da central termoelétrica da Represa de Santa Branca no rio Paraíba do Sul, sendo previsto consumo de $350 \mathrm{~m} 3 / \mathrm{h}(520 \mathrm{~m} 3 / \mathrm{h}$ de captação e 170 m3/h de retorno do Rio Paraíba).

Por conta das ações judiciais propostas em face do projeto, o seu processo de licenciamento ambiental foi suspenso em 2002. A Eletroger Ltda. foi desativada e sucedida pela AES Tietê, concessionária que assumiu a Eletropaulo Metropolitana Eletricidade de São Paulo S.A. com a privatização, e a Light Serviços de Eletricidade S.A. no tocante a pendências relativas à ação judicial que versa sobre a área onde se pretendia implantar a UTE Santa Branca. 
Representantes do Departamento Jurídico da AES Tietê e da Light Serviços de Eletricidade S.A. informaram que não mais se encontravam, nessas empresas, as pessoas que cuidavam do projeto da UTE Santa Branca na época do seu licenciamento, e que não haviam sido designadas outras para esse propósito (informação verbal) ${ }^{156}$.

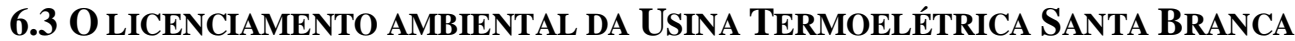

Considerando-se o recorte material proposto para este trabalho, este item será focado na identificação e na avaliação das intervenções do MPE-SP no processo de licenciamento ambiental da UTE Santa Branca, sendo que outros fatos serão apresentados apenas para efeito de contextualização. Um descritivo mais detalhado das etapas do processo de licenciamento da UTE Santa Branca consta do Anexo 3.

O processo administrativo de licenciamento da UTE Santa Branca recebeu o $\mathrm{n}^{\mathbf{o}}$ 13.696/99, aberto em 06.05.1999 na SMA, quando a Eletroger Ltda. protocolou no DAIA o RAP do projeto desse empreendimento. Seguiram-se os procedimentos exigidos no processo de licenciamento ambiental, como as publicações dos pedidos, agendamento de audiências públicas e a emissão da Licença Prévia, entre outras providências.

Diante desse protocolo, em 08.06.1999, a ONG Sociedade Ecológica de Santa Branca solicitou a realização de audiência pública para discussão do RAP.

\footnotetext{
${ }^{156}$ Informações fornecidas por Light (2008) em mensagem enviada por mariana.felix@light.com.br em 03 de dez.2008 e AES (2009) em mensagem enviada por cintia.santos@aes.com.em 02 de fev. 2009.
} 
Porém, pouco depois foi emitido o Parecer Técnico CPRN/DAIA 169/99 de 10.08.1999, por meio do qual o DAIA solicitou a elaboração de EIA-RIMA para o empreendimento, devido ao porte, à localização e a incertezas quanto às suas características técnicas e operacionais, com a incorporação da avaliação de impactos cumulativos por existirem, na mesma região, empreendimentos industriais e co-geração de efluentes gasosos, líquidos e sólidos.

Por meio desse Parecer Técnico foi também solicitada a apresentação de Plano de Trabalho para subsidiar a definição do Termo de Referência para a elaboração do EIA-RIMA.

Na 149ª Reunião Plenário Ordinária do Consema, de 17.11.1999 (Deliberação Consema 3.299/99), foi definido que o Plano de Trabalho para a elaboração do Termo de Referência do EIA-RIMA do processo de licenciamento ambiental da UTE Santa Branca seria analisado pela Câmara Técnica de Energia, Recursos, Hídricos e Saneamento daquele Conselho ${ }^{157}$.

Novamente por solicitação da Sociedade Ecológica de Santa Branca (que já havia solicitado a realização de audiências públicas à época da análise do RAP), foram realizadas audiências públicas para discussão do Plano de Trabalho da UTE Santa Branca: em 18.11.1999 em Santa Branca e em 16.12.1999 em Jacareí.

Por ocasião das audiências públicas, o empreendedor se comprometeu, junto à Prefeitura e à Câmara Municipal de Santa Branca, ao Presidente da Mesa da Audiência Pública e ao Promotor de Justiça de Santa Branca, a desistir do projeto se os estudos técnicos indicarem que aquele empreendimento deixará a qualidade do ar em conflito com os limites mais rigorosos da legislação brasileira e/ou da Organização Mundial de Saúde.

\footnotetext{
${ }^{157}$ Conforme exposto no item 2.3.2, o MPE-SP é uma das instituições que tem assento nessa Câmara, conforme Deliberação Consema 32/91.
} 
As audiências públicas seguiram o roteiro previsto pela Resolução Consema ${ }^{158}$ e, pelo que se verifica na transcrição das respectivas atas, houve diferentes manifestações dos participantes.

Embora tenha-se inscrito na audiência pública em Jacareí, o promotor estadual não estava mais presente quando foi chamado a se manifestar.

Em seu lugar, manifestou-se o representante do MP federal, o Procurador da República de São José dos Campos, no seguinte sentido: (i) ressaltar a necessidade de estudo sério no EIARIMA sobre a dispersão de gases em todo o Vale do Paraíba; (ii) incluir no EIA-RIMA, além de estudo sobre fauna, flora e qualidade de água, um estudo de ordem médica com um levantamento da saúde e condição pulmonar atuais da população para que se possa fazer um monitoramento e cotejamento das conseqüências do empreendimento no futuro; (iii) discutir a motorização da barragem de Santa Branca para verificar a necessidade de construção da termelétrica tendo em vista a geração de energia elétrica pela hidrelétrica; (iv) trazer a público o contrato de prestação de serviço da consultoria contratada para elaborar o EIA-RIMA, pois a seu ver um contrato que condicione parte do pagamento da remuneração à obtenção da licença fere o princípio da moralidade administrativa, na medida em que pode comprometer a imparcialidade da equipe multidisciplinar que elaborou o EIA-RIMA.

\footnotetext{
158 Conforme Resolução Consema 50/92, a audiência pública consiste nas seguintes partes: $1^{\mathrm{a}}$ parte - Abertura realizada pelo secretário do meio ambiente ou seu representante; $2^{\mathrm{a}}$ parte - Exposições: empreendedor (15'), equipe responsável pela elaboração do RAP ou EIA-RIMA (30') e representantes das entidades ambientalistas cadastradas no Consema (30'); $3^{\mathrm{a}}$ parte - Manifestação das entidades da sociedade civil (5' cada); $4^{\mathrm{a}}$ parte Manifestação dos presentes (2' cada), totalizando no conjunto 60'; 5a parte - Manifestação de membros do Consema (5' cada); $6^{a}$ parte - Manifestação de parlamentares (5' cada); $7^{\mathrm{a}}$ parte: Manifestação de Prefeitos e Secretários de Estado (5’ cada); $8^{a}$ parte - Réplicas do empreendedor (10'), equipe responsável pela elaboração do RAP ou EIA-RIMA (10’) e representantes das entidades ambientalistas cadastradas no Consema (10'); 9ª parte - Encerramento realizado pelo secretário do Meio Ambiente ou seu representante.
} 
Em 07.02.2000 ocorreu a primeira intervenção direta do MPE-SP no processo de licenciamento ambiental, quando essa instituição, pelo CAO-UMA, enviou ofício ao Secretário de Meio Ambiente impugnando o Plano de Trabalho para a elaboração do EIA da UTE Santa Branca apresentado e requerendo complementações.

Nesse ofício, constava a seguinte recomendação: que os estudos e a coleta de dados concernentes à velocidade e à direção dos ventos na região levassem em consideração um período mínimo de 2 anos, consideradas as variações das diferentes estações do ano.

Em 24.02.2000 ${ }^{159}$, em resposta ao ofício acima do MPE-SP, o DAIA informou que os estudos necessários para a avaliação de impactos ambientais sobre a qualidade do ar do local e da região serão definidos pela Cetesb em conjunto com o DAIA, que constarão do Termo de Referência do empreendimento do EIA, juntamente com as sugestões apresentadas à SMA por meio de audiência pública, câmara técnica ou diretamente ao DAIA.

As ONGs Sociedade Ecológica de Santa Branca e Sociedade Amigos do Bairro D’Angola também encaminharam sugestões e quesitos complementares no Plano de Trabalho do EIA.

O MPE-SP solicitou informações ao Instituto Nacional de Pesquisas Espaciais (INPE) a respeito das condições climáticas e direção e velocidade dos ventos na região onde se estava pretendendo implantar o empreendimento.

${ }^{159}$ Ressalte-se que antes de emitir essa resposta, havia sido realizada a $4^{\mathrm{a}}$ reunião ordinária da Câmara Técnica de Energia, Recursos Hídricos e Saneamento do Consema, em 10.02.2000, e ainda a constatação pelo DAIA da necessidade de manifestação do Ibama pelo fato de a alternativa locacional proposta estar inserida nos limites da Área de Proteção Ambiental - APA do Paraíba do Sul. A qual foi obtida antes da reunião no Consema. 
Em resposta a essa solicitação, em 17. 04.2000, o INPE emitiu um parecer assinado por Jesus Marden dos Santos, no qual, em síntese, constava que: (i) não há medições das condições climáticas, em especial no que tange aos ventos (direção e velocidade) no Município de Santa Branca; e (ii) considerando apenas as observações locais, sem referência a uma rede regional, o tempo mínimo exigido para conhecer o comportamento do vento (direção e velocidade) será de 36 meses, conforme recomendado pelos padrões internacionais.

O Parecer do INPE justifica a necessidade desse prazo pelo fato de o estudo do mesoclima de uma região ser feito com base no raciocínio de que as condições meteorológicas em períodos de 24 horas e 10 dias seguidos perdurarem ou modificarem regularmente numa área correspondente a um círculo de $30 \mathrm{~km}$ de raio.

A partir do que, para poder estudar as condições climáticas de uma área que não possuía histórico de observações meteorológicas, far-se-ia necessário referenciar uma estação meteorológica neste local durante períodos característicos, que podem variar de acordo com a estação do ano, e uma série de estações em seu entorno em cada um dos períodos considerados, com séries observacionais de, no mínimo, 3 anos.

Justifica ainda que estudos de correlação de estatística climatológica permitem gerar a informação necessária ao desenvolvimento de modelos de micro e meso-escala inferindo, inclusive, parametrizações de elementos ou fatores de clima.

Por sua vez, o empreendedor consultou, por intermédio da Somar Meteorologia - Consultoria, Projetos e Serviços em Meteorologia e Oceanografia, o Instituto de Astronomia, Geofísica e Ciências Atmosféricas da Universidade de São Paulo (IAG-USP). 
A equipe técnica do IAG-USP elaborou simulações cujos resultados, diferentemente do Parecer do INPE, demonstravam que a influência da operação da UTE no Município de Santa Branca sobre a poluição do ar da região seria muito pequena. E que, com base na simulação que estava sendo feita, os seus resultados seriam muito próximos aos que seriam obtidos com a instalação de estações de meteorologia e o monitoramento de seus dados por 2-3 anos.

De acordo com Silva Dias (2008), que coordenou a equipe do IAG-USP nesses trabalhos, foi adotado um modelo alternativo e inovador ao utilizado pelo INPE, baseado no software de última geração na época, o Regional Atmospheric Modeling System (RAMS) ${ }^{160}$.

O RAMS permitia fazer simulações das condições atmosféricas com alta precisão, enfocando as diversas influências na geração de ventos na atmosfera, sejam as de origem topográfica, sejam as devidas à passagem de sistemas de tempo pela área de interesse. Os resultados obtidos por essa modelagem eram bastante aceitos cientificamente.

Conforme explicado pela pesquisadora, como os dados observados na região de Santa Branca eram relativamente escassos, o RAMS apresentou-se como uma ferramenta imprescindível para obtenção de variáveis importantes, como a velocidade dos ventos, a altura da inversão térmica, as temperaturas e as chuvas.

A conclusão a que se chegou com base nessa simulação foi a de que o incremento à poluição atmosférica por conta da UTE, em termos de pluma adicional de influência, seria muito pequeno, da ordem de $0,1 \%$. Sendo um valor tão pequeno, não se justificaria a realização de medições por um período de 2 anos, conforme havia sido proposto pelo INPE.

\footnotetext{
${ }^{160}$ De acordo com informações fornecidas por Silva Dias em entrevista realizada em 22.12.2008. Informações sobre a entrevistada constam do Anexo 6.
} 
A razão para o pequeno grau de interferência devia-se ao fato de que, embora não possuísse muitas fontes de poluição atmosférica instaladas no próprio Município, Santa Branca não tinha um ar tão puro por conta da poluição, carregada pelo vento, vinda do Vale do Paraíba e das rodovias que a circundam (Rodovia Dutra e Rodovia Carvalho Pinto).

Ainda de acordo com Silva Dias (2009), embora tenha sido aventado, não foram estabelecidos entendimentos com o INPE sobre os resultados da simulação para que, tecnicamente, se chegasse a um consenso. De qualquer forma, uma equipe de técnicos, incluindo ela própria, apresentou a simulação feita em Power Point para o Promotor de Justiça de Santa Branca, que foi bastante agressivo durante a reunião e contestava a exposição dos técnicos.

Mondelo (2009), que chefiava a consultoria contratada pela Eletroger Ltda. para a elaboração do EIA-RIMA, corrobora com essa informação, acrescentando que a atuação daquele Promotor de Justiça de Santa Branca era agressiva sem razão justificada, ao não permitir que os técnicos expusessem os seus trabalhos e intimidando as discussões ${ }^{161}$.

Em 17.05.2000, a Eletroger protocolou o novo Plano de Trabalho para elaboração do EIA da UTE Santa Branca, em resposta ao qual, em 19.02.2001, a Coordenadoria de Licenciamento Ambiental e de Proteção de Recursos Naturais da SMA encaminhou à Eletroger o Termo de Referência para a elaboração do EIA-RIMA.

\footnotetext{
${ }^{161}$ Informações fornecidas por Mondelo em entrevista realizada em 07.01.2009. Referências sobre o entrevistado constam do Anexo 6.
} 
Nessa ocasião, fez-se perceber a primeira intervenção judicial motivada pelo MPE-SP embora indireta - sobre o processo administrativo do licenciamento ambiental da UTE Santa Branca: a Ação Civil Pública nº 42/00.

Essa ação judicial foi proposta pelo Promotor de Justiça de Santa Branca em face de Light Serviços de Eletricidade S.A., visando a obrigar esta empresa a promover a recuperação de áreas degradadas determinada como condicionante da licença prévia emitida pela SMA para as obras de motorização da UHE Santa Branca.

Pela argumentação trazida pelo MPE-SP e acatada em sede de liminar pelo Juízo de Santa Branca, a área objeto do litígio não poderia ter outra destinação que não a de recuperação, sendo que nessa área estava sendo proposta a instalação da UTE Santa Branca. Por essa razão, a Eletroger Ltda. ingressou nessa ação como terceira interessada, visto que uma eventual decisão judicial favorável ao MPE-SP poderia levar à inviabilidade da UTE Santa Branca.

Por envolver o projeto em licenciamento, o DAIA enviou ofício ao Juízo de Santa Branca indagando a respeito da possibilidade no prosseguimento do licenciamento ambiental prévio da UTE Santa Branca, tendo em vista que a área a ser utilizada estava sub judice. A Juíza respondeu que não caberia ao Juízo deliberar sobre o assunto.

Essa questão foi dirimida internamente pela SMA. Conforme Informação AT/CPRN datada de 29.08.2001, o DAIA não poderia interromper o licenciamento ambiental da UTE Santa Branca, pois tal atitude infringiria direito líquido e certo do particular. 
Ademais, o prosseguimento das análises não significaria situação de irreversibilidade de dano ao meio ambiente, já que até a etapa que autorize a instalação do empreendimento, caberia à autoridade ambiental indeferir a opção locacional, de acordo com o caso.

Esse entendimento mostrou-se acertado, pois a liminar concedida foi suspensa pelo Tribunal de Justiça pouco depois da decisão administrativa de dar continuidade ao processo.

Tendo sido retomado o licenciamento ambiental pela SMA, em 20.10.2001 foram publicadas as datas em que seriam realizadas as duas audiências publicas sobre o EIA-RIMA da UTE Santa Branca: 21.11.2001, em Jacareí, e 22.11.2001, em Santa Branca.

Nas duas audiências públicas não foram registradas quaisquer manifestações por parte do MPE-SP, nem solicitação de tempo para sua manifestação.

Essas audiências públicas tiveram repercussão dentro do Consema, por terem sido as mais barulhentas que haviam sido realizadas, com a utilização de apitos e de outros instrumentos sonoros que impediram ou que pelo menos dificultaram a manifestação dos empreendedores e de seus representantes (consultores, especialistas e participantes favoráveis ao projeto) fosse ouvida pelos presentes e, portanto, inviabilizando a chance de haver algum debate ${ }^{162}$.

Os problemas ocorridos nessas ocasiões motivaram, posteriormente, aquele Conselho a tomar a decisão de proibir o ingresso de aparelhos sonoros nas audiências públicas ${ }^{163}$.

${ }^{162}$ Conforme informações verbais fornecidas por Silva Dias (2008), Seara Filho (2008) e Mondelo (2009), em entrevistas realizadas, respectivamente, em 22.12.2008, 15.11.2008 e 09.01.2009. Referências aos entrevistados constam do Anexo 6.

${ }^{163}$ Conforme informações verbais fornecidas por Seara Filho em 15.11.2009. 
Após receber o Parecer Cetesb 017/01/EQ/EE favorável à viabilidade ambiental do projeto, a Licença Especial no 04/2001 do Ibama e com a edição da Resolução ANEEL n 664 autorizando a implantação da UTE Santa Branca, o DAIA manifestou-se pela viabilidade ambiental do empreendimento no Parecer Técnico CPRN/DAIA/010/02 de 11.01.2002.

Emitido esse parecer do DAIA, conforme se verifica na Ata da $69^{a}$ Reunião Extraordinária do Plenário do Consema realizada em 21.01.2002, foi feita a exposição do projeto, dos impactos ambientais previstos e das medidas mitigatórias e compensatórias previstas, seguida de debate entre os conselheiros e os representantes e consultores do empreendedor.

Houve diversas manifestações, com destaque para o conselheiro do MPE-SP que apresentou as seguintes recomendações a serem inseridas no processo de licenciamento ambiental do empreendimento, adicionalmente ao Parecer do DAIA: (i) que o projeto de urbanização das margens do Rio Paraíba do Sul, em Jacareí, priorize a recuperação das áreas de preservação permanente; (ii) que relatórios sobre o cumprimento das exigências e/ou recomendações constantes do EIA-RIMA e do Parecer CPRN/DAIA 10/2002 sejam periodicamente encaminhados à SMA e apresentados ao Consema; (iii) que o plano de manejo para a APA do Rio Paraíba do Sul privilegie a recuperação e a manutenção das áreas de preservação permanente e a preservação de maciços florestais e de corredores de fauna; (iv) que, em 180 dias após a implementação do programa de compensação ambiental, sejam demonstrados os resultados obtidos e, caso algum dos projetos eventualmente não se viabilize, seja apresentado relatório apontando os impedimentos, para que o Conselho delibere sobre outra destinação a ser dada aos recursos; e (v) que sejam apresentadas ao Consema, a cada seis meses, avaliações da qualidade do ar, comparando-a com a da situação anterior à instalação do empreendimento. 
Em seguida, outros dois conselheiros apresentaram outras propostas de emenda, totalizando 9 emendas: (vi) que seja feito levantamento semestral junto ao Serviço de Saúde das ocorrências de problemas nas vias respiratórias das pessoas relacionadas com substâncias químicas provenientes das atividades do empreendimento; (vii) que sejam realizados monitoramento e estudo sobre a fauna e a flora, inclusive aquáticas, apresentando-se ao Consema relatórios semestrais ou sugestões a serem levadas em consideração nos futuros licenciamentos de projetos para a Região do Vale do Paraíba; (viii) que seja apresentado plano de contingência do empreendimento; e (ix) que, dos $2 \%$ do valor do empreendimento destinados ao programa de compensação ambiental, $0,5 \%$ seja usado para realização de estudos e pesquisas sobre a sustentabilidade da região.

Ao final, o Secretário Executivo do Consema colocou o assunto em votação e declarou que, se houvesse consenso em relação às emendas apresentadas, estas seriam juntadas ao parecer do DAIA para que fossem votadas em conjunto; os conselheiros concordaram com a inclusão das propostas feitas pelo MPE-SP e pelos outros dois conselheiros ao Parecer do DAIA.

Em seguida, o Parecer Técnico e as emendas apresentadas foram aprovadas conjuntamente, recebendo 18 votos favoráveis, 2 contrários e tendo sido objeto de 2 abstenções. Desta forma, o Plenário do Consema deliberou pela viabilidade ambiental da UTE Santa Branca.

Superadas essas etapas técnicas e de participação popular do licenciamento ambiental, em 08.02.2002, foi emitida a Licença Prévia 00470 para a UTE Santa Branca. 
Conforme analisado no item 3.1, a Licença Prévia apenas atesta a viabilidade ambiental do projeto; a etapa seguinte do licenciamento ambiental seria a obtenção de licença de instalação para que fosse autorizada sua implantação.

Uma semana depois, em 15.02.2002, a Fazenda Pública do Estado de São Paulo foi informada sobre o deferimento de liminar pela Vara Única da Comarca de Santa Branca, nos autos da Ação Civil Pública 505/2001 proposta pelo MPE-SP, determinando a suspensão do processo de licenciamento da UTE Santa Branca pelo prazo de 120 dias.

Daí, em 02.07.2002, a Vara Única da Comarca de Santa Branca deferiu os pedidos formulados pelo MPE-SP na Ação Civil Pública 505/2001 condenando a SMA na obrigação de não fazer, consistente em abster-se de conceder licenças prévias, de instalação e de operação para a UTE Santa Branca, nas áreas abrangidas pelo artigo 166 da lei Orgânica do Município, e na obrigação de fazer, para revogar licença(s) que tenha(m) sido concedida(s).

Em cumprimento à determinação judicial, a SMA revogou a Licença Prévia 00470. O empreendedor apresentou diversos recursos administrativos requerendo que não fosse cancelada a licença até a decisão final por parte do Tribunal de Justiça, mas a Consultoria Jurídica da SMA, a Procuradoria Geral do Estado e a Assessoria Jurídica do Governo indeferiram o pedido porque a SMA teria de obedecer à determinação judicial.

Em 26.04.2004, o Governador do Estado confirmou o cancelamento da licença prévia concedida pela SMA à UTE Santa Branca, ratificando a decisão administrativa do Secretário de Meio Ambiente que já havia se posicionado nesse sentido após o recebimento da determinação do Juízo da Comarca de Santa Branca. 
Desta forma, tendo-se encerrado as instâncias recursais no âmbito administrativo, tornou-se definitiva a decisão da SMA de acatar a determinação judicial e assim cancelar a licença prévia do empreendimento. Em agosto de 2004, o DAIA arquivou o processo de licenciamento ambiental da UTE Santa Branca.

\subsection{INTERVENÇÕES JUDICIAIS NO LICENCIAMENTO AMBIENTAL DA UTE SANTA BRANCA}

Houve duas intervenções judiciais propostas pelo MPE-SP que envolveram o licenciamento ambiental do projeto da UTE Santa Branca.

A seguir serão apresentados os tópicos principais, focando nos fatos e evitando-se entrar em detalhes processuais para não dificultar a compreensão daqueles que não estiverem afeitos ao conhecimento do Direito Processual, além de não interessarem diretamente ao desenvolvimento do presente estudo. Não obstante, uma síntese do andamento processual dessas ações judiciais consta, respectivamente, dos Anexos 4 e 5. 


\subsubsection{Ação civil pública $n^{0}$ 42/00}

Em 13.02.2000 o MPE-SP propôs uma Ação Civil Pública perante a Vara Única da Comarca de Santa Branca em face de Light Serviços de Eletricidade S.A., objetivando a condenação desta em (i) obrigação de fazer, consistente na execução integral do Plano de Recuperação de Áreas Degradadas (PRAD) nas áreas que foram afetadas quando da construção da barragem de Santa Branca; e (ii) obrigação de não fazer, no sentido de abster-se de dar outra destinação à área que não fosse a inequívoca recuperação ambiental.

Considerando-se que a alternativa locacional proposta para a implantação da UTE Santa Branca estava contemplada na área em litígio, a Eletroger Ltda. acompanhou o processo como terceira interessada extraprocessual, ou seja, sem ingressar oficialmente na ação.

O segundo pedido - a abstenção de qualquer outra destinação à área que não fosse a sua recuperação ambiental - foi requerido e deferido em sede de liminar, ou seja, antecipadamente ao julgamento do mérito, em 23.02.2000.

No curso do processo judicial, houve ingresso da Sociedade Ecológica de Santa Branca e posteriormente da Sociedade Amigos de Bairro D’ Angola como assistentes litisconsorciais no pólo ativo da ação ${ }^{164}$. Note-se que são as mesmas ONGs que mostraram-se contrárias a esse empreendimento, conforme verificado no item 6.3.

\footnotetext{
${ }^{164}$ Assistente litisconsorcial é a parte que, sem ser autor nem réu, ingressa na ação judicial por também ter interesse em que a sentença seja favorável à parte de quem se propõe ser assistente (conforme artigos 50 a 55 da Lei Federal 5.869/73 (Código de Processo Civil).
} 
Houve também audiências para tentativa de conciliação, que não resultaram frutíferas porque, por um lado, a Light Serviços de Eletricidade S.A. considerava cumpridas as medidas do PRAD e, por outro, o MPE-SP e as ONGs entendiam o contrário e que não poderia haver a implantação de nenhum outro projeto que não fosse a recuperação requerida.

Na fase de provas, o perito judicial emitiu laudo concluindo que a instalação da UTE não resultaria na ocorrência de impactos ambientais inadmissíveis à área objeto do litígio.

Com base nesse laudo pericial, em agosto de 2001 a Light Serviços de Eletricidade S.A. requereu ao Juízo que fosse revogada a liminar concedida e, mediante indeferimento desse pedido, interpôs recurso ao Tribunal de Justiça, que reformou a decisão do Juízo de $1^{\mathrm{a}}$ instância e deferiu que fosse suspensa a liminar proibitiva do processamento de estudos para licenciamento do projeto da UTE Santa Branca na parte do terreno objeto do PRAD.

Em 15.07.2002, o Juízo da Vara de Santa Branca condenou a Light Serviços de Eletricidade S.A. ao cumprimento da obrigação de fazer, para que executasse integralmente o PRAD, determinando ainda que o processo de recuperação deveria ser iniciado em 6 meses, sob a supervisão dos órgãos ambientais competentes.

A sentença também condenou a Light serviços de Eletricidade S.A. em obrigação de não fazer, consistente em abster-se de dar outra destinação à área objeto da recuperação e paralisar qualquer atividade que não fosse a plena e inequívoca recuperação ambiental, fixando a multa diária no valor de 1.000 salários mínimos em casos de descumprimento da decisão. 
A Light Serviços de Eletricidade S.A., o MPE-SP e a assistente litisconsorcial Sociedade Ecológica de Santa Branca interpuseram diversos e sucessivos recursos.

No que se refere à possível instalação da UTE Santa Branca, inda na segunda instância, o Tribunal de Justiça de São Paulo entendeu que, por conta da ação em andamento, não decorreria nenhum impedimento que justificasse a condução ou a paralisação do licenciamento ambiental desse outro projeto que não estava diretamente colocado em litígio.

As partes continuaram com recursos e o feito chegou ao Superior Tribunal de Justiça. Ao final, a Light Serviços de Eletricidade S.A. foi condenada a finalizar o PRAD e, em 13.10.2009 ${ }^{165}$, essa ação encontrava-se na fase de execução da sentença judicial, aguardando vistoria do órgão ambiental no local.

Já em relação à UTE Santa Branca, permaneceu a decisão do Tribunal de Justiça, no sentido de que essa ação não interfere no licenciamento ambiental daquele projeto.

\subsubsection{Ação civil pública 505/01}

Em 20.11.2001, o MPE de Santa Branca propôs a Ação Civil Pública 505/01, perante a Vara Única da Comarca de Santa Branca, em face Fazenda Pública do Estado de São Paulo ${ }^{166}$.

\footnotetext{
165 Última atualização feita antes do encerramento da presente trabalho.

${ }^{166}$ Conforme analisado no item 6.1, a SMA não tem personalidade jurídica, sendo representada em juízo pela Fazenda Pública do Estado de São Paulo.
} 
O objeto visava a que a Fazenda Pública não outorgasse licenças ambientais para a UTE Santa Branca e, caso tais licenças já tivessem sido concedidas, que fossem as mesmas revogadas e ainda fosse aplicado o pagamento de multa diária no valor de 1.000 salários mínimos por dia, por descumprimento da obrigação de fazer ou de não fazer.

A Eletroger Ltda. ingressou como parte interessada, compondo litisconsórcio passivo ${ }^{167}$ com a Fazenda Pública do Estado de São Paulo.

O fundamento apresentado para a propositura da ação civil pública, bem como para o pedido de liminar, consistia na alegada existência de um impedimento na legislação municipal de Santa Branca que vedaria a implantação da UTE Santa Branca, além de questões relacionadas à degradação ambiental que decorreria desse empreendimento.

De acordo com o MPE-SP, o artigo 166 da Lei Orgânica do Município de Santa Branca prevê, como seu patrimônio ecológico, "insuscetíveis de outra destinação", entre outros, o Rio Paraíba do Sul, nos seus limites, e seus afluentes. Como o projeto da UTE Santa Branca previa a sua implantação nessa área, o MPE-SP alegava que não seria possível, do ponto de vista jurídico, a instalação desse empreendimento.

Em 26.12.2001, o Juízo de $1^{\mathrm{a}}$ instância indeferiu o pedido de liminar, por não vislumbrar os requisitos necessários para a concessão da medida requerida. Assim, o licenciamento ambiental teve prosseguimento, com a emissão do Parecer Técnico CPRN/DAIA/010/2002 de 11.01.2002 concluindo pela viabilidade ambiental do empreendimento e a deliberação favorável do Consema em 21.01.2002, com posterior emissão da Licença Prévia.

\footnotetext{
${ }^{167}$ Litisconsórcio pode ser entendido como a pluralidade de partes litigando num processo, seja como autor, seja como ré (daí o litisconsórcio ativo e passivo, respectivamente).
} 
Em 04.02.2002, o MPE-SP apontou argumentos contrários à deliberação do Consema, enfatizando os riscos ao meio ambiente caso o licenciamento ambiental do projeto da UTE Santa Branca tivesse prosseguimento.

Em 13.02.2002, o Juízo deferiu o pedido de liminar com base nesses argumentos; assim, foi suspenso o licenciamento ambiental pelo prazo de 120 dias, sob pena de multa diária, equivalente a 1.000 salários mínimos pelo descumprimento.

A Light Serviços de Eletricidade S.A. ingressou como assistente, por ter interesse no deslinde do caso já que envolveria a utilização futura de parte de seu imóvel e, juntamente com a Eletroger Ltda., interpôs recursos contra a decisão que deferiu a suspensão do licenciamento.

Paralelamente, em 01.07.2002, a Juíza de $1^{\mathrm{a}}$ instância condenou a Fazenda Pública na obrigação de não fazer, consistente em abster-se de conceder as licenças prévias, de instalação e de operação para a UTE Santa Branca nas áreas abrangidas pelo artigo 166 da Lei Orgânica do Município, e obrigação de fazer, para revogar a(s) licença(s) já concedida(s), fixando multa diária no valor de 1.000 salários mínimos por dia, por descumprimento da decisão.

Novos recursos foram interpostos perante a primeira e a segunda instância, pela Eletroger Ltda. e também pela Fazenda Pública do Estado de São Paulo. 
Após quase sete anos da propositura dessa ação civil pública, em 31.07.2008, a Câmara

Especial do Meio Ambiente do Tribunal de Justiça deu provimento à Eletroger Ltda. e à Fazenda Pública do Estado de São Paulo por unanimidade, reformando a sentença da Juíza da Comarca de Santa Branca por entender que

(...) o procedimento de licenciamento ambiental para instalação da Termoelétrica de Santa Branca contou com a aprovação de todos os órgãos incumbidos do mister de zelar pela preservação ambiental e pela correção técnica do próprio sistema a ser implementado;

(...) a documentação existente não demonstra inviabilidade ambiental do projeto, tampouco evidencia algum dano ecológico irreparável cuja magnitude impediria a instalação de fonte de energia vital para o país,

(...) A discussão que se instalou em redor do artigo 166 da Lei Orgânica do Município de Santra Branca não tem razão de ser, data máxima vênia, daqueles que perfilham tese diversa, porquanto a lei Orgânica daquele Município não obstou o progresso econômico sustentável;

(...) o artigo 166 da Lei Orgânica do Município não apresenta amplitude para inviabilizar o estudo de implantação de quaisquer projetos que utilizem as águas do Rio Paraíba do Sul, bastando que a implantação se faça com observância de critérios e normas técnicas apuradas e criteriosamente acompanhadas e fiscalizadas pelos órgãos ambientais incumbidos do mister ${ }^{168}$.

Não houve interposição de recurso nem por parte do MPE-SP nem pelas ONGs e, assim, essa decisão transitou em julgado em 18.02.2009. Retornando à Vara de origem, o processo foi arquivado em 06.07.2009. Quase cinco anos após o processo de licenciamento ambiental da UTE Santa Branca ter sido arquivada pelo DAIA, após a decisão de cancelamento da licença prévia emitida àquele projeto, em atendimento à decisão judicial.

\footnotetext{
${ }^{168}$ Conforme fls. 17-19 do Voto 7699, ao qual acompanharam os votos dos outros dois desembargadores, nos autos da Apelação com revisão n ${ }^{\circ}$ 408.001-5/8-00. Acompanharam esse voto a presidente e relatora, bem como o terceiro juiz pelo Voto 22.365 .
} 


\section{ENTREVISTAS}

Foram realizadas entrevistas com representantes da SMA, da Cetesb, da Procuradoria do Patrimônio Imobiliário (cujos Procuradores do Estado atuam judicialmente em nome da SMA), do MPE-SP e do CAO-UMA. Pessoas que participaram do processo de licenciamento ambiental da UTE Santa Branca também foram ouvidas para relatar os fatos havidos naquele procedimento, bem como suas impressões.

A escolha dos entrevistados se pautou não somente pelo cargo ocupado à época da entrevista, mas principalmente pelas experiências por eles vivenciados que tivessem relação com o empreendimento estudado em profundidade ou com a interação do órgão ambiental com o MPE-SP, cujos relatos poderiam trazer dados e impressões relevantes à pesquisa.

Para evitar indução de respostas, optou-se por não adotar questionários pré-elaborados, mas um formato aberto com questões norteadoras do trabalho, adaptado de forma personalizada para cada entrevistado, de acordo com a formação pessoal, o envolvimento individual com essas questões e com a contribuição que se esperava de cada um.

Desta forma, feitas as perguntas principais pré-selecionadas, foi oferecida liberdade ao entrevistado para se manifestar com maior profundidade a respeito dos tópicos sobre os quais tivesse maiores informações, impressões e opiniões a respeito, bem como a de ampliar o escopo inicialmente previsto, de acordo com a experiência e o conhecimento individual relacionados à atuação do MPE-SP e ao licenciamento ambiental conduzido pela SMA. 
As características individuais de cada entrevistado, a sua maior ou menor disponibilidade para fornecer informações e expressar suas opiniões, o grau de comprometimento para tornar público os seus comentários pessoais, a formação profissional, as diferentes experiências vivenciadas, entre outros fatores personalizados de cada entrevistado, diferenciaram cada entrevista das demais.

Como resultado, foram colhidos comentários enriquecedores e informações importantes que, no que se referiam ao escopo deste trabalho, foram nele transpostos ao longo de seu desenvolvimento, tanto com a finalidade de preencher lacunas de informações não identificados nos documentos oficiais, quanto a de confirmar alguns desses dados na prática.

Para garantir conforto para os entrevistados quanto ao conteúdo que poderia vir a ser utilizado no presente trabalho (e, assim tornado público), as principais informações e comentários por eles apresentados nas entrevistas foram consolidados em forma de texto e encaminhados para sua revisão e aprovação. Após o que, procedeu-se à utilização desses dados.

Ao longo do trabalho, foram citados nominalmente os entrevistados constantes do Anexo 6, que desta forma se constituíram em fonte primária de informações para o desenvolvimento desta pesquisa. No referido Anexo 6, consta uma apresentação sintética desses entrevistados, em ordem alfabética, focada nos descritivos que demonstram as razões que levaram à escolha dos mesmos como entrevistados e a credibilidade das informações fornecidas. 


\section{ANÁLISE E CONCLUSÕES}

Conforme analisado neste trabalho, o licenciamento ambiental e o EIA são instrumentos que a Política Nacional de Meio Ambiente conferiu à Administração Pública para, na busca do desenvolvimento sustentável, possibilitar a implantação e o funcionamento de novos empreendimentos e atividades, ao mesmo tempo em que seja resguardado o equilíbrio ecológico pela avaliação prévia dos impactos ambientais.

A partir da década de 1980, a legislação ordinária atribuiu ao MP brasileiro a competência para tutelar o meio ambiente, estando presente nas ações judiciais como autora ou como fiscal da lei, tendo ainda o diferencial de dispor de instrumentos exclusivos para participar da gestão de conflitos ambientais inclusive fora da esfera judicial.

O papel de tutelar o meio ambiente foi consolidado pela CF-88, que também conferiu ao MP a atribuição inovadora de zelar pelo efetivo cumprimento de órgãos do Poder Público e serviços de relevância pública aos direitos garantidos constitucionalmente, entre os quais se inclui o do direito ao meio ambiente ecologicamente equilibrado, com base na qual o MP passou a fiscalizar processos de licenciamento ambiental conduzidos pela Administração Pública.

No processo de licenciamento ambiental conduzido pela SMA, estão previstos os seguintes momentos para a manifestação dos membros do MPE-SP: (i) nas audiências públicas, cuja realização o MP pode solicitar e para as quais são convidados oficialmente o representante do MPE-SP no Consema e o promotor da Comarca local; (ii) nos plenários do Consema (como conselheiro e com direito a voto); e (iii) nas câmaras técnicas daquele Conselho. 
No entanto, verificou-se que a participação do MPE-SP nessas esferas administrativas é relativamente pouco representativa.

No Consema, o representante do MPE-SP naquela instância administrativa segue a diretiva institucional de se abster na hora da votação para não vincular os promotores das Comarcas locais às decisões e manifestações tomadas dentro do Conselho. Nas audiências públicas, a participação de membros do MP não é mandatória nem incentivada institucionalmente e, de fato, a sua manifestação nesses eventos não é regra geral.

Se a atuação do MPE-SP dentro do âmbito administrativo é comedida, a representatividade dessa instituição no acompanhamento de processos de licenciamento por meio da instauração de inquéritos civis ou pela propositura de ações civis públicas é reconhecida pelos próprios membros e também pela Administração Pública.

As motivações apresentadas são variadas. No caso de empreendimentos de geração de energia elétrica no período em estudo, aquela instituição incentivou o acompanhamento de processos de licenciamento ambiental de usinas termelétricas sob a alegação de fiscalizar e evitar que etapas necessárias fossem atropeladas em prol de políticas de incentivo à implantação de alternativas rápidas de fornecimento de energia.

Há também situações em que o projeto sob licenciamento ambiental tem como empreendedor o mesmo Executivo do qual o órgão licenciador faz parte, de que podem resultar em pressões sobre o órgão ambiental que poderiam interferir em seu trabalho. A atuação do MP visa a evitar o risco de que interesses políticos acabem afetando o exercício do órgão administrativo no seu dever de proteger o meio ecologicamente equilibrado. 
Porém, ao mesmo tempo em que se verificam justificativas e méritos, dessa atuação surgem novos conflitos, os quais consistiram na base da avaliação crítica do presente trabalho: entre o órgão ambiental (legitimado para conduzir o licenciamento ambiental) e o MP (legitimado para realizar a fiscalização desse serviço público).

A legislação prevê requisitos e restrições a serem observadas no licenciamento ambiental e, muitas vezes, remete à discricionariedade do órgão ambiental a tomada de decisões sobre as situações não previstas em normas, estabelecendo condições e sugerindo alterações ou complementações para que, no final desse processo, seja ou não emitida a licença ambiental que autoriza a implantação e o funcionamento lícitos do empreendimento proposto.

Desta forma, a aplicação da legislação, na prática, dependerá, em muitas ocasiões, da avaliação técnica a ser exercida pelos órgãos ambientais.

Para embasar o convencimento dos membros do MPE-SP quanto a eventuais irregularidades técnicas que justifiquem a impugnação dos trabalhos conduzidos pelo órgão ambiental, aquela instituição conta primordialmente com assistentes técnicos de sua confiança. Ocorre que essa estrutura comporta contradições.

A legislação prevê que o EIA-RIMA seja elaborado por equipe multidisciplinar; a estrutura da SMA possibilita a avaliação desses estudos por profissionais de diferentes formações. Porém, para defender o respeito à legalidade do processo de licenciamento ambiental, o MPE-SP conta com um número limitado de assistentes técnicos para atender a todas as promotorias de meio ambiente do Estado e, portanto, limitada também será a multidisciplinaridade da equipe técnica ministerial envolvida na avaliação desses trabalhos. 
Havendo divergência entre o laudo técnico do MP e o do órgão ambiental, na visão daquele, prevalecerá o entendimento de sua fonte de referência técnica. Dotada da legitimidade para fiscalizar e dos instrumentos que lhe foram conferidos, a instituição ministerial possui um poder de coercibilidade para fazer com que seu posicionamento prevaleça sobre a legitimidade do órgão ambiental para licenciar, sob o risco de propositura de ações judiciais.

Pessoalmente, os agentes públicos que exercem o trabalho de condução do licenciamento ambiental podem responder por ações de improbidade caso o MP entenda que houve desvio de conduta na condução do processo de licenciamento ambiental. Por sua vez, é mais difícil vislumbrar a possibilidade de propositura de tais ações em face dos membros do MP (e mesmo de seus assistentes técnicos, que se encontram amparados na estrutura ministerial).

No estudo de caso, verificou-se que o licenciamento da UTE Santa Branca foi suspenso em dois momentos por intervenções promovidas pelo MPE-SP, sendo que na última a licença ambiental foi cancelada e o processo acabou sendo arquivado.

A principal irregularidade apontada pelo MPE-SP - o impedimento existente na legislação municipal para a implantação de uma usina termelétrica no local proposto - não havia sido levada pelo MPE-SP ao conhecimento da Administração Pública, em nenhuma das oportunidades previstas pela estrutura institucional da SMA para a participação do MPE-SP.

Foi escolhida a via judicial, com todas as desvantagens desse caminho quando se trata de proteção do meio ambiente. 
Conforme foi analisado no presente trabalho, as duas ações judiciais foram propostas antes da reunião do plenário do Consema, sendo que nessa ocasião o promotor de justiça do CAOUMA (que representava o MPE-SP no Consema) apresentou questionamentos e recomendações que foram votados, aceitos e incluídos na relação de exigências feitas pelo DAIA para as próximas etapas do licenciamento ambiental da UTE Santa Branca. Naqueles, não figuravam os questionamentos que fundamentaram as ações judiciais.

Os argumentos da ação proposta nada tinham a ver com os questionamentos apresentados pelo membro do MPE-SP no Consema, nem no que foi discutido nas audiências, nem na recomendação feita ao Secretário de Meio Ambiente quanto à inclusão de tópicos adicionais no plano de trabalho para a elaboração do EIA-RIMA.

Assim, não houve sintonia entre a atuação dos dois órgãos do MPE-SP (o CAO e a Promotoria de Justiça) em relação ao licenciamento ambiental do mesmo projeto.

Ao final, as alegações de irregularidades apresentadas pelo MPE-SP foram consideradas improcedentes pelo Judiciário. Na ação civil pública no 40/00, o Tribunal de Justiça entendeu que essa demanda não deveria interferir no licenciamento da UTE Santa Branca.

Na ação civil pública $n^{\circ} 505 / 01$, o Tribunal de Justiça afastou as irregularidades apontadas pelo MPE-SP, em decisão que transitou em julgado, posto que o MPE-SP não interpôs recurso. Assim, esse processo foi arquivado em julho de 2009, cerca de sete anos e oito meses após a propositura da ação civil pública que cancelou a licença emitida pela SMA. 
Depois desse tempo, não se prevê a retomada do projeto da UTE Santa Branca, cujo licenciamento foi suspenso por conta de supostos impedimentos para a implantação do empreendimento, que poderia ter sido discutida (e talvez) dirimida na própria esfera administrativa do licenciamento ambiental, antes da emissão da licença ambiental.

Outro ponto a ser considerado é que o aumento no número de empreendimentos de geração é uma necessidade em função do aumento crescente da demanda energética no País. Destarte, mesmo que um determinado projeto de geração de energia não seja implantado, algum outro precisará entrar em funcionamento, em alguma outra localidade ou então sob outra forma (em relação à matriz energética e à capacidade de geração), sob o risco de ocorrência de novo déficit energético, com as consequiências sociais dele decorrentes.

Nesse contexto, a despeito dos esforços dessa instituição para o melhor exercício de suas atribuições constitucionais, com os incentivos ao aprimoramento profissional de seus membros, com a criação de grupos de atuação cada vez mais especializados para a percepção da problemática ambiental (em especial no que se refere a essa instituição do Estado de São Paulo), chegou-se a algumas conclusões críticas em relação à forma de atuação do MPE-SP em relação a processos de licenciamento ambiental.

Pelo que foi verificado, a função institucional estudada neste trabalho ("zelar pelo efetivo respeito dos Poderes Públicos e dos serviços de relevância pública aos direitos assegurados nesta Constituição, promovendo as medidas necessárias a sua garantia”) está sendo utilizada pelo MPE-SP mais pela vertente da função institucional de "promover o inquérito civil e a ação civil pública" prevista em outro inciso do mesmo dispositivo constitucional. 
Ocorre que a função objeto deste estudo é mais ampla, não se limitando à instauração de procedimentos ou à propositura de ações judiciais, mas contemplando outras medidas que permitam fiscalizar o exercício do órgão administrativo na relevante função de conduzir processos de licenciamento ambiental.

No tocante à SMA, o MPE-SP conta com momentos no licenciamento ambiental que lhe permitem ter acesso a informações sobre os projetos dentro da própria estrutura do órgão administrativo. Nesses momentos, o MPE-SP tem condições de apresentar questionamentos, solicitar esclarecimentos, recomendar a inclusão de exigências e complementações, manifestar oposições, otimizando seus recursos para exercer sua função de fiscalização, bem como os do órgão ambiental para conduzir processos de licenciamento ambiental.

Embora haja controvérsias quanto à participação do MP nesses conselhos e nesses foros de discussão, entendemos que ela é importante não somente porque prestigia a legitimidade do órgão licenciador no exercício de suas funções, como principalmente oferece a oportunidade para que as questões sejam dirimidas nos momentos apropriados antes da tomada de decisões pelo órgão ambiental (emissão ou não de licença ambiental).

Desta forma também poderiam ser reduzidas as intervenções posteriores a essas decisões, conferindo maior segurança aos empreendedores (e àqueles com eles envolvidos) com relação à legitimidade do órgão licenciador. Observando-se que o cancelamento de licenças emitidas afeta a segurança jurídica e compromete a presunção de legitimidade dos atos administrativos, razão pela qual deveria ocorrer em situações realmente excepcionais. 
Constatou-se também que a estrutura do MPE-SP privilegia a independência funcional de cada promotor, mas pode gerar contradições quanto à unicidade da instituição. A adoção de uma postura institucional unificada por parte do MP dentro das diferentes etapas do licenciamento ambiental poderia contribuir para equacionar parte desses conflitos.

Precisa também ser considerado que as intervenções do MP no processo de licenciamento ambiental de empreendimentos de geração de energia elétrica podem refletir sobre os direitos sociais e os próprios interesses que aquela instituição pretende tutelar. Dessa forma, ao invés de uma abordagem estritamente legalista, pautada em uma atuação formalmente correta, a atuação do MP precisaria considerar o intrincado mecanismo sistêmico no qual se insere, por meio de uma postura efetivamente equacionadora dos problemas ambientais.

Portanto, a estrutura pela qual o MPE-SP exerce a fiscalização sobre o licenciamento ambiental conduzido pela SMA pode acabar por exacerbar as tensões existentes e por criar contradições por vezes críticas, favorecendo a perpetuação dos conflitos. Daí a necessidade de uma integração sistêmica dos diversos agentes e fatores para favorecer o atendimento aos objetivos ambientais - e por que não - sociais envolvidos. 


\section{REFERÊNCIAS BIBLIOGRÁFICAS ${ }^{169}$}

AGÊNCIA NACIONAL DE ENERGIA ELÉTRICA (ANEEL). Capacidade Geração Brasil. Banco de informações de geração. Disponível em: http://www.aneel.gov.br/area.cfm?idArea=15\&idPerfil=2. Acesso em 12 ago. 2009.

AGÊNCIA NACIONAL DE ENERGIA ELÉTRICA (ANEEL). Resumo Estadual. Banco de informações de geração. Disponível em: http://www.aneel.gov.br/area.cfm?idArea=15\&idPerfil=2. Acesso em 12 ago. 2009.

AGRA FILHO, Severino Soares. Conflitos ambientais e os instrumentos da Política Nacional de Meio Ambiente. eGesta, v. 4, n. 2, abr.-jun./2008, p. 127-140.

ANTUNES, Paulo de Bessa. Interesse nacional e licenciamento ambiental. Disponível em: www.oeco.com.br. Acesso em 24 abr. 2007.

BARDELIN, César Endrigo Alves. Os efeitos do racionamento de energia elétrica ocorrido no Brasil em 2001 e 2002 com ênfase no consumo de energia elétrica. 2004. Dissertação (Mestrado em Engenharia - Escola Politécnica), Universidade de São Paulo, São Paulo, 2004.

BENJAMIN, Antônio Herman de Vasconcellos e. Um novo modelo para o Ministério Público na proteção do meio ambiente. Revista de Direito Ambiental, São Paulo, 3(10):8-12, abr-jun., 1998.

. Citizen Action Norte-Americana e a Tutela Ambiental. BDJur, Brasília, DF, 1991. Disponível em: <http://bdjur.stj.gov.br/dspace/handle/2011/9454>. Acesso em: 29 mai. 2007.

BOBBIO, Norberto. A Era dos Direitos, tradução de Carlos Nelson Coutinho, $4^{\mathrm{a}}$ reimpressão. Rio de Janeiro: Campus, 1992.

BRASIL. Vara Única da Comarca de Santa Branca. Ação Civil Pública 42/00. Objeto: condenação da requerida em obrigação de fazer, consistente na execução integral do Plano de Recuperação de Áreas Degradadas (PRAD) referente às áreas que foram degradadas quando da construção da barragem de Santa Branca e obrigação de não fazer, no sentido de abster-se de dar outra destinação à área que não a sua plena e inequívoca recuperação ambiental. Autor: Ministério Público do Estado de São Paulo. Ré: Light Serviços de Eletricidade S.A. Data da propositura: 13 fev. 2009.

\footnotetext{
${ }^{169}$ De acordo com: ASSOCIAÇÃO BRASILEIRA DE NORMAS TÉCNICAS. NBR 6023: informação e documentação, referências, elaboração. Rio de Janeiro, 2002.
} 
BRASIL. Vara Única da Comarca de Santa Branca. Ação Civil Pública 505/01. Objeto: condenação da requerida em não outorgar licença prévia de instalação da Usina Termoelétrica no Rio Paraíba do Sul em Santa Branca e, caso já tenham sido concedidas, que sejam as mesmas revogadas. Autor: Ministério Público do Estado de São Paulo. Ré: Fazenda Pública do Estado de São Paulo. Data da propositura: 20 nov. 2001.

BUGALHO, Nelson R. Instrumentos de controle extraprocessual: aspectos relevantes do inquérito civil público, do compromisso de ajustamento e da recomendação em matéria de proteção do meio ambiente. Revista de Direito Ambiental, São Paulo, vol. 37, jan.-mar., 2005, p. 96-112.

COELHO, Suani Teixeira; PALETTA, Carlos Eduardo Machado; FREITAS, Marcos Aurélio Vasconcelos de (edit.). Medidas mitigadoras para a redução de emissões de gases de efeito estufa na geração termelétrica. Brasília: Dupligráfica, 2001.

COIMBRA, José de Ávila Aguiar. Considerações sobre a Interdisciplinaridade. In: Phillippi Jr., Arlindo et al. Interdisciplinaridade em ciências ambientais. São Paulo: Signus Editora, 2000, p. 52-70.

COSTA MACHADO. Código de Processo Civil interpretado e anotado, $2^{\mathrm{a}}$ ed. São Paulo: 2008, p. 172.

DAVID, René. Os grandes sistemas do direito contemporâneo, $2^{\mathrm{a}}$ ed. São Paulo: Martins Fontes, 1993.

DEPARTAMENTO DE AVALIAÇÃO DE IMPACTO AMBIENTAL. Energia1997_2006. Mensagem enviada por giselik@cprn.sp.gov.br. São Paulo, 16 ago. 2007.

DE MIO, Geisa Paganini; FERREIRA FILHO, Edward; CAMPOS, José Roberto. O inquérito civil e o termo de ajustamento de conduta para resolução de conflitos ambientais. Revista de Direito Ambiental, $\mathrm{n}^{\mathrm{o}}$ 39, ano 10, Editora Revista dos Tribunais, 2005, p. 92-102.

DEPARTAMENTO DE AVALIAÇÃO DE IMPACTO AMBIENTAL. Energia1997_2006. Mensagem enviada por giselik@cprn.sp.gov.br. São Paulo, 16 ago. 2007.

DERANI, Cristiane. Direito ambiental econômico. São Paulo: Editora Saraiva, 2008.

DI PIETRO, Maria Sylvia Zanella . Direito administrativo. 15ª ed. São Paulo: Atlas, 2003.

EMPRESA DE PESQUISAS ENERGÉTICAS (EPE). Resenha mensal do mercado de energia elétrica. Brasília, Ano II, nº 15, dez. de 2008.

FERNANDES, Marília de Castro Torres. Ministério Público em São Paulo: eficácia da função institucional de zelar pelo direito à saúde. 1999. Dissertação (Mestrado em Direito - Faculdade de Direito), Universidade de São Paulo, São Paulo, 1999. 
FEYERABEND, Paul. Consolando o especialista. In: LAKATOS, Imre; MUSGRAVE, Alan. A crítica e o desenvolvimento do conhecimento. São Paulo: Editora Cultrix e Editora da Universidade de São Paulo, 1979.

FINK, Daniel Roberto, PEREIRA, Márcio Silva. Vegetação de preservação permanente em meio ambiente urbano. Revista de Direito Ambiental, São Paulo, RT, n. 2, 1996, p. 77 90.

FINK, Daniel R., SOUZA, L. A. Alternativa à ação civil pública ambiental (reflexões sobre as vantagens do Termo de Ajustamento de Conduta). In: $4^{\circ}$ Congresso de Meio Ambiente do Ministério Público do Estado de São Paulo e $5^{\circ}$ Encontro Anaul dos Grupos Especiais de Promotores de Justiça de Meio Ambiente. Águas de São Pedro - SP, 15 18 nov. 2000, p. 128-148.

FINK, Daniel Roberto, DAWALIBI, Marcelo, e ALONSO Jr., Hamilton. Aspectos jurídicos do licenciamento ambiental, $3^{\mathrm{a}}$ ed. Rio de Janeiro: Forense Universitária, 2002.

FONTES, Paulo Gustavo Guedes. O controle da administração pelo Ministério Público. Belo Horizonte: Del Rey, 2006.

FURRIELA, Rachel Biderman. Gestão ambiental e espaços de participação pública: análise das práticas no Conselho Estadual do Meio Ambiente de São Paulo. In: ABRAMOVAY, Ricardo (org.). Construindo a ciência ambiental. São Paulo: Annablume - Fapesp, 2002, p. 361-383.

GAVRONSKI, Alexandre Amaral. Das origens ao futuro da lei de ação civil pública: o desafio de garantir acesso à justiça com efetividade. In: MILARÉ, Édis (coord.). A ação civil pública após 20 anos: efetividade e desafios. São Paulo: Editora Revista dos Tribunais, 2005, p. 16-32.

GOLDEMBERG, José e VILLANUEVA, Luz Dondero. Energia, meio ambiente $e$ desenvolvimento, $2^{\mathrm{a}}$ ed. São Paulo: Editora da Universidade de São Paulo, 2003.

GRINOVER, Ada Pellegrini. Defesa do meio ambiente em juízo como conquista da cidadania. Revista CEJ, V. 3, n. 9, set./dez. 1999, p. 95-99.

Rumo a um código brasileiro de processos coletivos. In: MILARÉ, Édis. A ação civil pública após 20 anos: efetividade e desafios. São Paulo: Editora Revista dos Tribunais, 2005, p. 13-16.

INATOMI, Thais Aya Hassan; UDAETA, Miguel Edgar Morales. Análise dos impactos ambientais na produção de energia dentro do planejamento integrado de recursos. In: III Workshop Brasil-Japão em Energia, Meio Ambiente e Desenvolvimento Sustentável, 2005, Campinas. Anais. Campinas: Unicamp, 2005.

INSTITUTO BRASILEIRO DE GEOGRAFIA E ESTATÍSTICA (IBGE). Tabela 793 População residente: Publicação completa. Sistema IBGE de Recuperação Automática (SIDRA). Brasília: 2008. Disponível em http://www.sidra.ibge.gov.br/bda/tabela/listabl.asp?z=cd\&o=17\&i=P\&c=793. Acesso em 10 ago. 2009. 
JATAHY, Carlos Roberto de C. O Ministério Público e o Estado Democrático de Direito: perspectivas constitucionais de atuação institucional. Rio de Janeiro: Lumen Juris, 2007.

JOLLIVET, Marcel; PAVÉ, Alain. O meio ambiente: questões e perspectivas para a pesquisa. In: VIEIRA, Paulo Freire; WEBER, Jacques (org.). Gestão de recursos naturais renováveis e desenvolvimento - novos desafios para a pesquisa ambiental, $3^{\text {a }}$ ed. São Paulo: Editora Cortez, 2002, p. 53-112.

JUKOVSKI, Vera Lúcia R. S. Considerações sobre a ação civil pública no direito ambiental. Revista CEJ, v.1, n3, set./dez 1997, p. 21-32.

KUHN, Thomas S. Lógica ou descoberta ou psicologia da pesquisa. In: LAKATOS, Imre; MUSGRAVE, Alan. A crítica e o desenvolvimento do conhecimento. São Paulo: Editora Cultrix e Editora da Universidade de São Paulo, 1979.

LATOUR, Buno. Jamais fomos modernos: ensaio de antropologia simétrica. Rio de Janeiro: Editora 34, 1994.

LEFF, Enrique. Complexidade, interdisciplinaridade e saber ambiental. In: Phillippi Jr., Arlindo et al. Interdisciplinaridade em ciências ambientais. São Paulo: Signus Editora, 2000. Epistemologia ambiental. São Paulo: Cortez, 2001. . Saber ambiental. Petrópolis: Vozes, 2001.

MACEDO JUNIOR., Ronaldo Porto. Ministério Público Brasileiro: um novo ator político. In: VIGLIAR, José Marcelo Menezes e MACEDO JR, Ronaldo Porto (coord.), Ministério Público II: democracia. São Paulo: Atlas, 1999, p. 103-114.

. O quarto poder e o terceiro setor. O MP e as organizações não governamentais sem fins lucrativos - estratégias para o futuro. In: VIGLIAR, José Marcelo Menezes e MACEDO JR, Ronaldo Porto (coord.), Ministério Público II: democracia. São Paulo: Atlas, 1999, p. 248-263.

- O Ministério Público 500 anos depois do descobrimento. Cadernos de Direito e Cidadania, v. 02, n. 1. São Paulo: Iedc, 2000, p. 71-88.

MACHADO, Paulo Affonso Leme. Direito ambiental brasileiro. $16^{\mathrm{a}}$ ed. São Paulo: Malheiros, 2008.

MAGEE, Bryan. As idéias de Popper. São Paulo: Cultrix, 1974.

MANCUSO, Rodolfo de Camargo. Interesses difusos: conceito e legitimação para agir. $6^{\mathbf{a}}$ ed. São Paulo: Revista dos Tribunais, 2004.

Ação civil pública em defesa do meio ambiente, do patrimônio cultural e dos consumidores. 10 a ed. São Paulo: RT, 2007. 
MARTÍNEZ ALIER, Joan. O ecologismo dos pobres. São Paulo: Editora Contexto, 2007.

MASTERMAN, Margareth. A natureza de um paradigma. In: LAKATOS, Imre; MUSGRAVE, Alan. A crítica e o desenvolvimento do conhecimento. São Paulo: Editora Cultrix e Editora da Universidade de São Paulo, 1979.

MAZZILLI, Hugo Nigri. Ministério Público, $3^{\mathrm{a}}$ ed. São Paulo: Editora Damásio de Jesus, 2005.

Inquérito civil e poder investigatório do MP. In: MILARÉ, Édis (coord). A ação civil pública após 20 anos: efetividade e desafios. São Paulo: Editora Revista dos Tribunais, 2005, p. 221-245.

MILARÉ, Édis. Direito do ambiente: a gestão ambiental em foco: doutrina, jurisprudência, glossário. 6a ed. São Paulo: Editora Revista dos Tribunais, 2009.

MILARÉ, Édis; BENJAMIN, Antonio Herman V. Estudo prévio de impacto ambiental: teoria, prática e legislação. São Paulo: Editora RT, 1993.

MINISTÉRIO DE MINAS E ENERGIA. Plano Decenal de Expansão de Energia Elétrica 2006-2015 - Sumário Executivo. Brasília, DF, 2006. Acesso em 08 set. 2006.

MINISTÉRIO DE MINAS E ENERGIA. Plano Nacional 2030 - Modelo de expansão. Brasília, DF, 2006. Disponível em http://www.mme.gov.br. Acesso em 08 set. 2006.

MINISTÉRIO PÚBLICO DO ESTADO DE SÃO PAULO. O papel do Ministério Público na defesa do meio ambiente - Centro de Apoio Operacional de Urbanismo e Meio Ambiente do Ministério Público de São Paulo. Mensagem enviada por akaoui@mp.sp.gov.br. São Paulo, 17 mai. 2007.

MINISTÉRIO PÚBLICO DO ESTADO DE SÃO PAUlO. Atos do Conselho - Conselho Superior do Ministério Público de São Paulo. Disponível em <http://www.mp.sp.gov.br/portal/page/portal/conselho_superior/atos>. Acesso em 07 dez. 2008.

MINISTÉRIO PÚBLICO DO ESTADO DE SÃO PAULO. Súmulas de jurisprudências do Conselho - Conselho Superior do Ministério Público de São Paulo. Disponível em <http://www.mp.sp.gov.br/portal/page/portal/conselho_superior/sumulas>. Acesso em 12 dez. 2009.

MINISTÉRIO PÚBLICO DO ESTADO DE SÃO PAULO. Centro de estudos e aperfeiçoamento funcional - Escola Superior do Ministério Público de São Paulo. Disponível em http://www.espm.sp.gov.br. Acesso em 27 set. 2009.

MORAES, Raimundo de Jesus Coelho de. Judicialização do licenciamento ambiental no Brasil: excesso ou garantia de participação. Revista de Direito Ambiental, vol. 38, ano 10. São Paulo: Editora RT, 2005, p. 219-223.

MORIN, Edgard. Ciência com consciência. Rio de Janeiro: Bertrand Brasil, 2002. 
NUSDEO, Fábio. Desenvolvimento e ecologia. São Paulo: Saraiva, 1975.

Economia do meio ambiente. In: PHILIPPI Jr., Arlindo e ALVES, Alaôr Caffé (edit.). Curso interdisciplinar de direito ambiental. Barueri: Manole, 2005, p. 717-738.

ODUM, Howard T.; ODUM, E. C.; BROWN, M. T.; LA HART, D.; BERSOK, C.; SENDZIMIR, J. Sistemas ambientais e políticas públicas. Campinas: Unicamp, 1997. Disponível em http://www.unicamp.br/fea/ortega/eco/index.htm. Acesso em 14 jun. 2007.

PAES, José Eduardo Sabo. O Ministério Público na construção do Estado Democrático de Direito. Brasília: Brasília Jurídica, 2003.

PASSOS, Maria de Fátima Salles Abreu. Gasoduto Bolívia-Brasil. Economia e Energia, ano II, $\mathrm{n}^{\circ} \quad 10$, set.-out. 1998. Brasília: 1988. Disponível em http://ecen.com/eee10/gasp.htm\#GASODUTO\%20BOLÍVIA\%20-\%20BRASIL. Acesso em 16 out. 2009.

PROCURADORIA GERAL DA REPÚBLICA, 4ª Câmara de Coordenação e Revisão, Meio Ambiente e Patrimônio Cultural. Roteiro para atuação do Ministério Público Federal em licenciamentos ambientais. $2^{\mathrm{a}}$ ed. Brasília: PGR, 2005.

PROENÇA, Luis Roberto. Inquérito Civil: atuação investigativa do Ministério Público a serviço da ampliação do acesso à justiça. São Paulo: Revista dos Tribunais, 2001.

QUEIROZ, Péricles Aurélio Lima de. Homenagem aos dez anos da Lei Complementar $\mathrm{n}^{\circ}$ 75/93. In: Boletim Científico - Escola Superior do Ministério Público da União. Brasília: ESMPU, ano II, n. 7, p. 9, abr.-jun. 2003.

RIBEIRO, Wagner Costa. O Brasil na ordem ambiental internacional. In: Patrimônio ambiental brasileiro. São Paulo: Edusp e IOESP, 2003. (org.). . A ordem ambiental internacional, $2^{\mathrm{a}}$ ed. São Paulo: Contexto, 2005.

SALLES, Carlos Alberto. A legitimação do MP para a defesa de direitos e garantias constitucionais. 1992. Dissertação (Mestrado em Direito - Faculdade de Direito), Universidade de São Paulo, São Paulo, 1992.

SANTOS, Maria Cecília Mac Dowell. A gestão jurídico-política dos conflitos ecológicos: um estudo sobre as reformas de proteção judicial do meio ambiente em Cubatão. 1990. Dissertação (Mestrado - Faculdade de Direito), Universidade de São Paulo, São Paulo, 1990.

SÃO PAULO. Companhia Ambiental de São Paulo. Organograma departamental com agências. Disponível em <http://www.cetesb.sp.gov.br/Institucional/documentos/organograma.pdf $>$. Acesso em 08 set. 2008 e em 02 nov. 2009. 
SÃO PAULO. Secretaria de Meio Ambiente. Processo no 13.696/99. Licenciamento de usina termoelétrica no Município de Santa Branca. Empreendedor: Eletroger Ltda. Início: 06 mai. 1999.

SÃO PAULO. Secretaria de Meio Ambiente. Estrutura organizacional. Disponível em <http://homologa.ambiente.sp.gov.br/sobreasecretaria/organo.htm> Acesso em 09 out. 2009.

SÃO PAULO. Secretaria de Meio Ambiente. Estrutura organizacional (após o advento do Decreto 54.653/09). Disponível em <http://www.ambiente.sp.gov.br/sma.php>. Acesso em 09 out. 2009.

SÃO PAULO. Secretaria de Saneamento e Energia. Boletim Informativo, v. 01. São Paulo, nov. de 2008.

VEIGA, José Eli da. Meio ambiente e desenvolvimento. São Paulo: Senac, 2006.

VIEIRA, Paulo Freire; WEBER, Jacques. Introdução geral: sociedades, naturezas e desenvolvimento viável. In: (org.). Gestão de recursos naturais renováveis e desenvolvimento - novos desafios para a pesquisa ambiental, $3^{\text {a }}$ ed. São Paulo: Editora Cortez, 2002, p. 17-49.

YIN, Robert K. Estudo de caso: planejamentos e métodos, $3^{\text {a }}$ ed. Porto Alegre: Bookman, 2005.

YOSHIDA, Consuelo Yatsuda Moromizato. Ação civil pública: judicialização dos conflitos e redução da litigiosidade. In: MILARÉ, Édis (coord.). A ação civil pública após 20 anos: efetividade e desafios. São Paulo: Editora Revista dos Tribunais, 2005, p. 111138. 


\section{NORMAS REFERENCIADAS}

AGÊNCIA NACIONAL DE ENERGIA E ELETRICIDADE (ANEEL). Resolução n ${ }^{\circ}$ 664, de 26 dez. 2001. Autoriza a empresa Eletroger Ltda. a estabelecer-se como Produtor Independente de Energia Elétrica mediante a implantação da central geradora termelétrica Santa Branca, localizada no Município de Santa Branca, Estado de São Paulo. Diário Oficial da União, Brasília, DF, 27 dez. 2001, seção 1, p. 182, v. 138, n. 245. Disponível em: < http://www.aneel.gov.br/cedoc/res2001664.pdf>. Acesso em: 08 out. 2009.

BRASIL. Lei $\mathrm{n}^{\circ}$ 6.803, de 03 jul. 1980. Dispõe sobre as diretrizes básicas para o zoneamento industrial nas áreas críticas de poluição e dá outras providências. Diário Oficial da União, Brasília, DF, 02 jul. 1980. Disponível em: <http://www.planalto.gov.br/ccivil_03/Leis/L6803.htm>. Acesso em: 08 out. 2009.

BRASIL. Lei no 6.938, de 31 ago. 1981. Dispõe sobre a Política Nacional do Meio Ambiente, seus fins e mecanismos de formulação e aplicação e dá outras providências. Diário Oficial da União, Brasília, DF, 02 set. 1981. Disponível em: <http://www.planalto.gov.br/ccivil_03/Leis/L6938.htm>. Acesso em: 08 out. 2009.

BRASIL. Lei complementar $n^{\circ} 40$, de 14 dez. 1981. Estabelece normas gerais a serem adotadas na organização do Ministério Público estadual. Diário Oficial da União, Brasília, DF, 15 dez. 1981. Disponível em: <http://www.planalto.gov.br/ccivil_03/Leis/LCP/Lcp40.htm>. Acesso em: 08 out. 2009.

BRASIL. Lei $n^{\circ} 7.347$, de 24 jul. 1985. Disciplina a ação civil pública de responsabilidade por danos causados ao meio-ambiente, ao consumidor, a bens e direitos de valor artístico, estético, histórico, turístico e paisagístico (VETADO) e dá outras providências. Diário Oficial da União, Brasília, DF, 25 julho. 1985. Disponível em: <http://www.planalto.gov.br/ccivil_03/Leis/L7347orig.htm>. Acesso em: 08 out. 2009.

BRASIL. Constituição (1988). Constituição da República Federativa do Brasil. Brasília, DF: Senado, 1988.

BRASIL. Lei $\mathrm{n}^{\circ}$ 8.078, de 11 set. 1990. Dispõe sobre a proteção do consumidor e dá outras providências. Diário Oficial da União, Brasília, DF, 12 set. 1990. Disponível em: <http://www.planalto.gov.br/ccivil_03/Leis/L8078.htm>. Acesso em: 08 out. 2009.

BRASIL. Lei $n^{\circ}$ 8.429, de 02 jun. 1992. Dispõe sobre as sanções aplicáveis aos agentes públicos nos casos de enriquecimento ilícito no exercício de mandato, cargo, emprego ou função na administração pública direta, indireta ou fundacional e dá outras providências. Diário Oficial da União, Brasília, DF, 3 jun. 1992. Disponível em: <http://www.planalto.gov.br/ccivil_03/Leis/L8429.htm>. Acesso em: 08 out. 2009. 
BRASIL. Lei no 8.625, de 12 fev. 1993. Institui a Lei Orgânica Nacional do Ministério Público, dispõe sobre normas gerais para a organização do Ministério Público dos Estados e dá outras providências. Diário Oficial da União, Brasília, DF, 15 fev. 1993. Disponível em: <http://www.planalto.gov.br/ccivil_03/Leis/L8625.htm>.Acesso em: 08 out. 2009.

BRASIL. Lei complementar $\mathrm{n}^{\circ}$ 75, de 20 mai. 1993. Dispõe sobre a organização, as atribuições e o estatuto do Ministério Público da União. Diário Oficial da União, Brasília, DF, 21 mai. 1993. Disponível em: <http://www.planalto.gov.br/ccivil_03/Leis/LCP/Lcp75.htm>. Acesso em: 08 out. 2009.

BRASIL. Decreto ${ }^{\circ}$ 3.371, de 24 fev. 2000. Institui, no âmbito do Ministério de Minas e Energia, o Programa Prioritário de Termeletricidade, e dá outras providências. Diário Oficial da União, Brasília, DF, 25 fev. 2000. Disponível em: <http://www.planalto.gov.br/ccivil_03/decreto/D3371.htm>. Acesso em: 08 out. 2009.

BRASIL. Medida Provisória nº 2.147, de 15 mai. 2001. Cria e instala a Câmara de Gestão da Crise de Energia Elétrica do Conselho de Governo, estabelece diretrizes para programas de enfrentamento da crise de energia elétrica e dá outras providências. Diário Oficial da União, Brasília, DF, 16 mai. 2001. Disponível em: < http://www.planalto.gov.br/ccivil_03/MPV/2147-.htm>. Acesso em: 08 out. 2009.

BRASIL. Medida Provisória nº 2.198, de 24 ago. 2001. Cria e instala a Câmara de Gestão da Crise de Energia Elétrica do Conselho de Governo, estabelece diretrizes para programas de enfrentamento da crise de energia elétrica e dá outras providências. Diário Oficial da União, Brasília, DF, 27 ago. 2001. Disponível em: < http://www.planalto.gov.br/ccivil_03/MPV/2148-1.htm>. Acesso em: 08 out. 2009.

BRASIL. Constituição (1988). Emenda Constitucional 32, de 11 set. 2001. Disponível em: <http://www.planalto.gov.br/ccivil_03/Constituicao/Emendas/Emc/emc32.htm>. Acesso em: 08 out. 2009.

BRASIL. Lei $n^{\circ}$ 10.847, de 15 mar. 2004. Autoriza a criação da Empresa de Pesquisa Energética - EPE e dá outras providências. Diário Oficial da União, Brasília, DF, 16 mar. 2004. Disponível em: <http://www.planalto.gov.br/ccivil_03/_Ato20042006/2004/Lei/L10.847.htm>. Acesso em: 08 out. 2009.

BRASIL. Constituição (1988). Emenda Constitucional 45, de 30 dez. 2004. Disponível em: <http://www.planalto.gov.br/ccivil_03/constituicao/Emendas/Emc/emc45.htm>. Acesso em: 08 out. 2009.

CONSELHO NACIONAL DO MEIO AMBIENTE (CONAMA). Resolução nº 001, de 23 jan. 1986. Dispõe sobre critérios básicos e diretrizes gerais para o Relatório de Impacto Ambiental - RIMA. Diário Oficial da União, Brasília, DF, 17 fev. 1986. Disponível em: <http://www.mma.gov.br/port/conama/legiabre.cfm?codlegi=23>. Acesso em: 08 out. 2009. 
CONSELHO NACIONAL DO MEIO AMBIENTE (CONAMA). Resolução nº 006, de 16 set. 1987. Dispõe sobre o licenciamento ambiental de obras do setor de geração de energia elétrica. Diário Oficial da União, Brasília, DF, 22 out. 1987. Disponível em: <http://www.mma.gov.br/port/conama/legiabre.cfm?codlegi=57>. Acesso em: 08 out. 2009.

CONSELHO NACIONAL DO MEIO AMBIENTE (CONAMA). Resolução no 009, de 03 dez. 1987. Dispõe sobre a questão de audiências Públicas. Diário Oficial da União, Brasília, DF, 05 jul. 1990. Disponível em: <http://www.mma.gov.br/port/conama/legiabre.cfm?codlegi=60>.Acesso em: 08 out. 2009.

CONSELHO NACIONAL DO MEIO AMBIENTE (CONAMA). Resolução $\mathrm{n}^{\circ}$ 237, de 22 dez. 1997. Regulamenta os aspectos de licenciamento ambiental estabelecidos na Política Nacional do Meio Ambiente. Diário Oficial da União, Brasília, DF, 22 dez. $1997 . \quad$ Disponível em: <http://www.mma.gov.br/port/conama/legiabre.cfm?codlegi=237>. Acesso em: 08 out. 2009.

CONSELHO NACIONAL DO MEIO AMBIENTE (CONAMA). Resolução n 279, de 27 jun. 2001. Estabelece procedimentos para o licenciamento ambiental simplificado de empreendimentos elétricos com pequeno potencial de impacto ambiental. Diário Oficial da União, Brasília, DF, 29 jun. 2001. Disponível em: <http://www.mma.gov.br/port/conama/legiabre.cfm?codlegi=277>. Acesso em: 08 out. 2009.

MINISTÉRIO DE MINAS E ENERGIA (MME). Portaria no 43, de 26 fev. 2000. Define as usinas termelétricas integrantes do programa prioritário, de acordo com os critérios de enquadramento estabelecidos pelo CAET. Diário Oficial da União, Brasília, DF, 28 fev. 2000, seção 1, p. 15 , v. 138, n. 41-E.

SÃO PAULO (Estado). Lei n ${ }^{\circ}$ 997, de 31 mai. 1976. Dispõe sobre o controle da poluição do meio ambiente. Diário Oficial do Estado, São Paulo, SP, sem data de publicação. Disponível em: <http://www.ambiente.sp.gov.br/legislacao/estadual/leis/1976\%20Lei\%20997.pdf>. Acesso em: 08 out. 2009.

SÃO PAULO (Estado). Decreto $n^{\circ} 8.468$, de 08 set. 1976. Aprova o Regulamento da Lei ${ }^{\circ}$ 997, de 31 de maio de 1976, que dispõe sobre a Prevenção e o Controle da Poluição do Meio Ambiente. Diário Oficial do Estado, São Paulo, SP, sem data de publicação. Disponível

em: <http://www.ambiente.sp.gov.br/legislacao/estadual/decretos/1976\%20Dec\%208468.p df $>$. Acesso em: 08 out. 2009.

SÃO PAULO (Estado). Decreto no 20.903, de 26 abr. 1983. Cria o Conselho Estadual do Meio Ambiente - Consema. Diário Oficial do Estado, São Paulo, SP, sem data de publicação. <http://www.al.sp.gov.br/repositorio/legislacao/decreto/1983/decreto\%20n.20.903,\%2 0de\%2026.04.1983.htm>. Acesso em: 08 out. 2009. 
SÃO PAULO (Estado). Lei Complementar n ${ }^{\circ}$ 478, de 18 jul. 1986. Lei Orgânica da Procuradoria Geral do Estado. Diário Oficial do Estado, São Paulo, SP, 18 jul. 1986. Disponível

em: <http://www.al.sp.gov.br/repositorio/legislacao/lei\%20complementar/1986/lei\%20co mplementar\%20n.478,\%20de\%2018.07.1986.htm>. Acesso em: 08 out. 2009.

SÃO PAULO (Estado). Lei Complementar nº 734, de 26 nov. 1993. Institui a Lei Orgânica do Ministério Público. Diário Oficial do Estado, São Paulo, SP, 27 nov. 1993. Disponível em: <http://www.al.sp.gov.br/legislacao/norma.do?id=14474>. Acesso em: 08 out. 2009.

SÃO PAULO (Estado). Decreto $n^{\circ}$ 53.027, de 26 mai. 2008. Reorganiza a Secretaria do Meio Ambiente - SMA e dá providências correlatas. Diário Oficial do Estado, São Paulo, SP, 27 mai. 2008 - Retificação em 17/06/2008 - Retificação em 18 jun. 2008. Disponível em: <http://www.legislacao.sp.gov.br/dg280202.nsf/5fb5269ed17b47ab83256cfb0050146 9/c07a534beabb59610325745600494a11 ?OpenDocument\&Highlight=0,53.027> . Acesso em: 08 out. 2009.

SÃO PAULO (Estado). Lei n ${ }^{\circ} 13.507$, de 23 abr. 2009. Dispõe sobre o Conselho Estadual da Meio Ambiente - Consema, e dá providências correlatas. Diário Oficial do Estado, São Paulo, SP, 24 abr. 2009. Disponível em: <http://www.legislacao.sp.gov.br/legislacao/index.htm>. Acesso em: 08 out. 2009.

SÃO PAULO (Estado). Lei n ${ }^{\circ} 13.542$, de 08 mai. 2009. Altera a denominação da CETESB Companhia de Tecnologia de Saneamento Ambiental e dá nova redação aos artigos $2^{\circ}$ e 10 da Lei n ${ }^{\circ} 118$, de 29 de junho de 1973. Diário Oficial do Estado, São Paulo, SP, 09 mai. 2009. Disponível em: < http://www.legislacao.sp.gov.br/legislacao/index.htm>. Acesso em: 08 out. 2009.

SÃO PAULO (Estado). Decreto $n^{\circ} 54.653$, de 06 ago. 2009. Reorganiza a Secretaria do Meio Ambiente - SMA e dá providências correlatas. Diário Oficial do Estado, São Paulo, SP, 07 ago. 2009 - Retificações em 19/08/2009. Disponível em: < http://www.legislacao.sp.gov.br/dg280202.nsf/5fb5269ed17b47ab83256cfb00501469/ 570411 ada697576a0325760b004e8ed2?OpenDocument\&Highlight=0,54.653,2009>. Acesso em: 08 out. 2009.

SÃO PAULO (Estado). Secretaria de Meio Ambiente. Resolução no 42, de 29 dez. 1994. Tramitação de Estudos de Impacto Ambiental. Diário Oficial do Estado, São Paulo, SP, 05 jan. $1995 . \quad$ Disponível em: <http://www.ambiente.sp.gov.br/legislacao/estadual/resolucoes/1994_Res_SMA_42.p df $>$. Acesso em: 08 out. 2009.

SÃO PAULO (Estado). Secretaria de Meio Ambiente. Resolução no 54, de 30 nov. 2004. Dispõe sobre procedimentos para o licenciamento ambiental no âmbito da Secretaria do Meio Ambiente. Diário Oficial do Estado, São Paulo, SP, 01 dez. 2004. Disponível em: <http://www.ambiente.sp.gov.br/legislacao/estadual/resolucoes/2004_Res_SMA_54.p df>. Acesso em: 08 out. 2009. 
SÃO PAULO (Estado). Secretaria de Meio Ambiente. Resolução no 22, de 16 mai. 2007. Dispõe sobre a execução do Projeto Ambiental Estratégico "Licenciamento Ambiental Unificado", que visa integrar e unificar o licenciamento ambiental no Estado de São Paulo, altera procedimentos para o licenciamento das atividades que especifica e dá outras providências. Diário Oficial do Estado, São Paulo, SP, 17 mai. 2007. Disponível em: http://www.ambiente.sp.gov.br/legislacao/estadual/resolucoes/2007_res_est_sma_22.p df>. Acesso em: 08 out. 2009.

SÃO PAULO (Estado). Secretaria de Meio Ambiente. Resolução no 03, de 14 jan. 2008. Dispõe sobre procedimentos do licenciamento ambiental de empreendimentos e atividades localizadas na Região Metropolitana de São Paulo e sujeitas ao regime do Balcão Único. Diário Oficial do Estado, São Paulo, SP, 15 jan. 2008. Disponível em: $<$ http://www.ambiente.sp.gov.br/legislacao/estadual/resolucoes/2008_res_est_sma_03. pdf $>$. Acesso em: 08 out. 2009.

SÃO PAULO (Estado). Conselho Estadual de Meio Ambiente. Resolução n ${ }^{\circ}$ 22, de 13 fev. 1987. Solicita ao Ministério Público embargo de empreendimento imobiliário na Prainha de Peruíbe. Sem dados de publicação. Disponível em: <http://www.ambiente.sp.gov.br/consemaDeliberacoes1987.php>. Acesso em: 08 out. 2009.

SÃO PAULO (Estado). Conselho Estadual de Meio Ambiente. Resolução no 28, de 10 jul. 1987. Constitui comissão técnica para elaboração de critérios de seleção dos RIMAs a serem submetidos ao Consema. Sem dados de publicação. Disponível em: <http://www.ambiente.sp.gov.br/consemaDeliberacoes1987.php>. Acesso em: 08 out. 2009.

SÃO PAULO (Estado). Conselho Estadual de Meio Ambiente. Resolução no 17 de 07 jul. 1989. Cria comissão técnica para estabelecer normas e procedimentos de análise para os Estudos de Impacto Ambiental de empreendimentos já iniciados. Sem dados de publicação.

Disponível

em: <http://www.ambiente.sp.gov.br/consemaDeliberacoes1989.php>. Acesso em: 08 out. 2009.

SÃO PAULO (Estado). Conselho Estadual de Meio Ambiente. Deliberações / Moções. Disponível em: <http://www.ambiente.sp.gov.br/consemaDeliberacoes.php>. Acesso em: 08 out. 2009.

SÃO PAULO (Estado). Conselho Estadual de Meio Ambiente. Regimento Interno. Disponível em:

<http://www.ambiente.sp.gov.br/uploads/arquivos/regimentointerno/regInterno_2008. pdf >. Acesso em: 08 out. 2009. 
ANEXO 1

Dados quantitativos da atuação do MPE-SP na tutela do meio ambiente

$\begin{array}{rrrrrrr} & \begin{array}{c}\text { ICs } \\ \text { inst. }\end{array} & \begin{array}{c}\text { ICs } \\ \text { and. }\end{array} & \begin{array}{l}\text { PPICs } \\ \text { inst. }\end{array} & \begin{array}{l}\text { PPIC } \\ \text { and. }\end{array} & \begin{array}{r}\text { ACP } \\ \text { ajuiz. }\end{array} & \begin{array}{r}\text { ACP } \\ \text { and. }\end{array} \\ \mathbf{1 9 9 7} & 378 & 1.900 & 2655 & 249 & 2.073 & 50 \\ \mathbf{1 9 9 8} & 708 & 2.039 & 3.472 & 234 & 2.308 & 113 \\ \mathbf{1 9 9 9} & 948 & 3.466 & 2.611 & 5.027 & 272 & 2.578 \\ \mathbf{2 0 0 0} & 1.317 & 4.702 & 2.657 & 7.313 & 229 & 2.807 \\ \mathbf{2 0 0 1} & 1.091 & 5.716 & 3.665 & 9.645 & 249 & 3.056 \\ \mathbf{2 0 0 2} & 2.401 & 7.707 & 2.578 & 11.478 & 256 & 3.312 \\ \mathbf{2 0 0 3} & 2.445 & 10.944 & 2.371 & 15.736 & 412 & 4.920 \\ \mathbf{2 0 0 4} & 3.024 & 12.828 & 2.866 & 17.537 & 407 & 5.327 \\ \mathbf{2 0 0 5} & 2.141 & 14.389 & 2.118 & 18.886 & 766 & 5.682 \\ \mathbf{2 0 0 6} & 2.288 & 16.677 & 1.901 & 20.787 & 477 & 6.159\end{array}$

Tabela 1: Dados quantitativos da atuação do Ministério Público na tutela do meio ambiente de 1997 a 2006 (fonte: CAO-UMA, 2007). Sendo ICs ins. (inquéritos civis instaurados); ICs and. (inquéritos civis em andamento); PPICs ins.: procedimentos preparatórios para inquéritos civis instaurados; PPICs and. (procedimentos preparatórios para inquéritos civis em andamento); ACP aj. (ações civis públicas ajuizadas); ACP and. (ações civis públicas em andamento); Man. Tec. ( manifestações técnicas). 


\section{ANEXO 2 \\ Estrutura organizacional da SMA (após o advento do Decreto Estadual 54.653/09)}

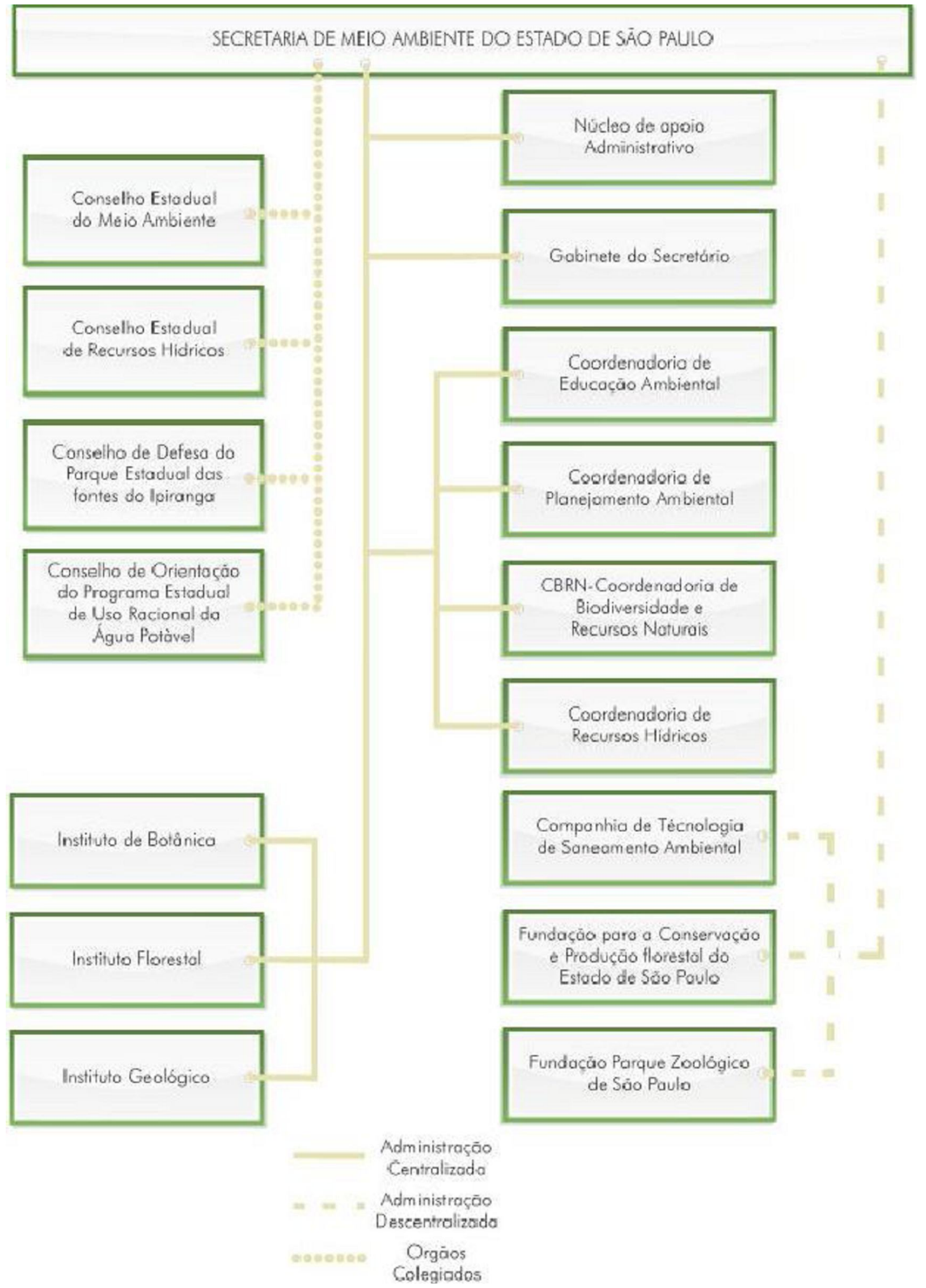


ANEXO 3

Síntese do processo de licenciamento ambiental da UTE Santa Branca

\begin{tabular}{|c|c|}
\hline DATA & ACONTECIMENTO \\
\hline 06.05.1999 & $\begin{array}{l}\text { A Eletroger Ltda. protocolou o Relatório Ambiental Preliminar (RAP) no } \\
\text { Departamento de Avaliação de Impacto Ambiental (DAIA), para a } \\
\text { construção de Usina Termoelétrica no Município de Santa Branca (UTE } \\
\text { Santa Branca). }\end{array}$ \\
\hline 28.05.1999 & $\begin{array}{l}\text { A Eletroger Ltda. tornou público o pedido de Licença Prévia feito à } \\
\text { Secretaria do Meio Ambiente (SMA). }\end{array}$ \\
\hline 08.06.1999 & $\begin{array}{l}\text { A Sociedade Ecológica de Santa Branca requereu a realização de audiência } \\
\text { pública para discussão do RAP. }\end{array}$ \\
\hline 10.08.1999 & $\begin{array}{l}\text { O DAIA solicitou a elaboração de Estudo de Impacto Ambiental (EIA) e } \\
\text { respectivo Relatório (RIMA) para o empreendimento. }\end{array}$ \\
\hline 17.11.1999 & $\begin{array}{l}\text { Por ocasião da } 149^{a} \text { Reunião Extraordinária do Plenário do Consema, foi } \\
\text { definido que o Plano de Trabalho para a celebração do Termo de Referência } \\
\text { do EIA-RIMA seria analisado pela Câmara Técnica de Energia, Recursos, } \\
\text { Hídricos e Saneamento daquele Conselho. }\end{array}$ \\
\hline 18.11.1999 & $\begin{array}{l}\text { Foi realizada audiência pública sobre o Plano de Trabalho da UTE Santa } \\
\text { Branca no Município de Santa Branca. }\end{array}$ \\
\hline 16.12 .1999 & $\begin{array}{l}\text { Foi realizada audiência pública sobre o Plano de Trabalho da UTE Santa } \\
\text { Branca no Município de Jacareí. }\end{array}$ \\
\hline 10.01 .2000 & $\begin{array}{l}\text { A Sociedade do Bairro D’Angola requereu à Cetesb informações sobre a } \\
\text { existência de levantamentos sobre a velocidade e direção dos ventos, } \\
\text { qualidade do ar, situação do solo e vegetação na região onde se pretendia } \\
\text { implantar a UTE Santa Branca. }\end{array}$ \\
\hline 07.02 .2000 & $\begin{array}{l}\text { A Coordenadoria de Meio Ambiente do Ministério Público impugnou } \\
\text { administrativamente o Plano de Trabalho para a elaboração do EIA. }\end{array}$ \\
\hline 10.02 .2000 & $\begin{array}{l}\text { Foi realizada a } 4^{\text {a }} \text { Reunião Ordinária da Câmara Técnica de Energia, } \\
\text { Recursos Hídricos e Saneamento do Consema, que discutiu o Plano de } \\
\text { Trabalho para elaboração do Termo de Referência do EIA-RIMA da UTE } \\
\text { Santa Branca. }\end{array}$ \\
\hline 18.02.2000 & $\begin{array}{l}\text { O DAIA informou que a alternativa locacional proposta estava inserida nos } \\
\text { limites da Área de Proteção Ambiental do Paraíba do Sul, de maneira que o } \\
\text { Instituto Brasileiro de Meio Ambiente e dos Recursos Naturais Renováveis } \\
\text { (Ibama) deveria manifestar-se. }\end{array}$ \\
\hline
\end{tabular}




\begin{tabular}{|c|c|}
\hline 01.03 .2000 & $\begin{array}{l}\text { A Sociedade Ecológica de Santa Branca encaminhou à SMA uma relação } \\
\text { de quesitos a serem contemplados no Plano de Trabalho do EIA-RIMA. }\end{array}$ \\
\hline 17.04.2000 & $\begin{array}{l}\text { O Instituto Nacional de Pesquisas Espaciais (INPE) elaborou em parecer } \\
\text { sobre as condições climáticas e direção e velocidade dos ventos na região } \\
\text { do empreendimento. }\end{array}$ \\
\hline 17.05.2000 & $\begin{array}{l}\text { A Eletroger Ltda. protocolou o Plano de Trabalho para elaboração do EIA } \\
\text { da UTE Santa Branca. }\end{array}$ \\
\hline 29.09.2000 & $\begin{array}{l}\text { O Ibama informou que, mediante a análise do EIA-RIMA, poderia conceder } \\
\text { uma Licença Especial para o empreendimento. }\end{array}$ \\
\hline 13.11.2000 & $\begin{array}{l}\text { A Eletroger Ltda. requereu ao DAIA uma manifestação sobre a eventual } \\
\text { aprovação do Plano de Trabalho e elaboração do Termo de Referência para } \\
\text { o EIA-RIMA da UTE Santa Branca. }\end{array}$ \\
\hline 19.02.2001 & $\begin{array}{l}\text { A Coordenadoria de Licenciamento Ambiental e de Proteção de Recursos } \\
\text { Naturais da SMA encaminhou à Eletroger Ltda. o Termo de Referência } \\
\text { para a elaboração do EIA-RIMA. }\end{array}$ \\
\hline 25.05.2001 & $\begin{array}{l}\text { A Coordenadoria de Licenciamento Ambiental e de Proteção de Recursos } \\
\text { Naturais da SMA encaminhou à Eletroger Ltda. uma pré-proposta de } \\
\text { Programa de Educação Ambiental, a ser implantado na região da Usina } \\
\text { Hidrelétrica Santa Branca. }\end{array}$ \\
\hline 10.07.2001 & $\begin{array}{l}\text { A Eletroger Ltda. encaminhou o RIMA do empreendimento aos vereadores } \\
\text { da Câmara Municipal da Santa Branca. }\end{array}$ \\
\hline 27.08 .2001 & $\begin{array}{l}\text { O DAIA informou à Coordenadoria de Licenciamento Ambiental e de } \\
\text { Proteção de Recursos Naturais da SMA que aguardaria o julgamento do } \\
\text { mérito da Ação Civil Pública no } 42 / 00 \text { ou uma manifestação formal do MM. } \\
\text { Juízo para prosseguir com o licenciamento ambiental. }\end{array}$ \\
\hline 29.08.2001 & $\begin{array}{l}\text { A Coordenadoria de Licenciamento Ambiental e de Proteção de Recursos } \\
\text { Naturais da SMA posicionou-se pelo prosseguimento do licenciamento } \\
\text { ambiental, conforme Informação AT/CPRN sem número dessa data. }\end{array}$ \\
\hline 20.10.2001 & $\begin{array}{l}\text { A SMA publicou as datas em que seriam realizadas as duas audiências } \\
\text { publicas sobre o EIA-RIMA da UTE Santa Branca (21.11.2001, em Jacareí, } \\
\text { e 22.11.2001, em Santa Branca). }\end{array}$ \\
\hline 30.11 .2001 & $\begin{array}{l}\text { A Eletroger Ltda. informou ao DAIA a suspensão da liminar concedida } \\
\text { pelo Juízo de Santa Branca, no âmbito da Ação Civil Pública n }{ }^{\circ} 42 / 00 \text {, pelo } \\
\text { Tribunal de Justiça do Estado de São Paulo. }\end{array}$ \\
\hline 30.11 .2001 & $\begin{array}{l}\text { A Cetesb manifestou-se pela viabilidade ambiental do empreendimento, } \\
\text { desde que atendidas as condições estabelecidas no Parecer Técnico } \\
017 / 01 / \mathrm{EQ} / \mathrm{EE} \text {. }\end{array}$ \\
\hline 11.12.2001 & $\begin{array}{l}\text { A Eletroger Ltda. enviou ao DAIA uma proposta de compensação } \\
\text { ambiental para a implantação da UTE Santa Branca. }\end{array}$ \\
\hline 20.12.2001 & O Ibama encaminhou para a Eletroger Ltda. a Licença Especial no 04/2001. \\
\hline
\end{tabular}




\begin{tabular}{|c|c|}
\hline 26.12.2001 & $\begin{array}{l}\text { Foi editada a Resolução ANEEL n }{ }^{\circ} \text { 664, autorizando a implantação da UTE } \\
\text { Santa Branca. }\end{array}$ \\
\hline 11.01.2002 & $\begin{array}{l}\text { Pelo Parecer Técnico CPRN/DAIA/010/02 o DAIA manifestou-se } \\
\text { favorável à viabilidade ambiental do empreendimento, desde que atendidas } \\
\text { as exigências e as medidas propostas no EIA e também as exigências } \\
\text { constantes do Parecer Cetesb n }{ }^{\circ} 017 / 01 / \mathrm{EQ} / \mathrm{EE} \text {. }\end{array}$ \\
\hline 23.01.2002 & $\begin{array}{l}\text { O Plenário do Consema, em sua } 69^{\text {a }} \text { Reunião Extraordinária, deliberou } \\
\text { favoravelmente sobre a viabilidade ambiental da UTE Santa Branca, } \\
\text { acrescentando exigências, recomendações, medidas mitigadoras e de } \\
\text { compensação, a serem incluídas no Parecer Cetesb n }{ }^{\circ} 017 / 01 / \mathrm{EQ} / \mathrm{EE} \text {. }\end{array}$ \\
\hline 08.02 .2002 & A Eletroger Ltda. obteve a Licença Prévia nº 00470 da UTE Santa Branca. \\
\hline 15.02.2002 & 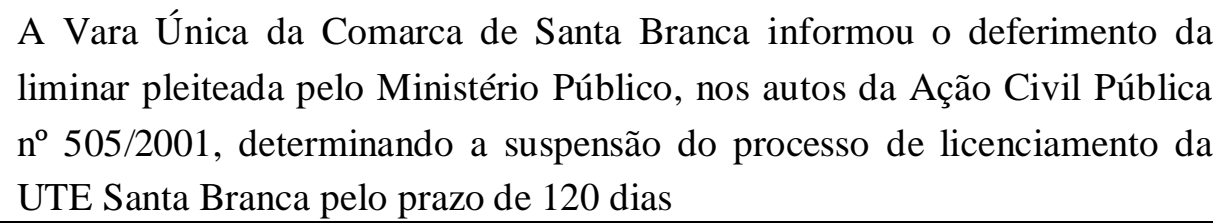 \\
\hline 28.05.2002 & $\begin{array}{l}\text { A Coordenadoria de Licenciamento Ambiental e de Proteção de Recursos } \\
\text { Naturais da SMA encaminhou ao Chefe de Gabinete do Secretário de } \\
\text { Estado do Meio ambiente informações sobre as condições climáticas e } \\
\text { formação de nevoeiros em razão da implantação da UTE Santa Branca, } \\
\text { concluindo que a partir da análise dos dados de monitoramento da } \\
\text { qualidade do ar da região a Cetesb poderia exigir controles adicionais para a } \\
\text { emissão atmosféricas (Informação Técnica } 016 / 02 / \mathrm{EQ} \text { ). }\end{array}$ \\
\hline 02.07 .2002 & $\begin{array}{l}\text { A Vara Única da Comarca de Santa Branca comunicou à SMA o } \\
\text { deferimento dos pedidos formulados na Ação Civil Pública no 505/2001 e a } \\
\text { condenação da SMA em obrigações de não fazer, consistente em abster-se } \\
\text { de conceder licenças prévias, de instalação e de operação para a UTE Santa } \\
\text { Branca, nas áreas abrangidas pelo artigo } 166 \text { da lei Orgânica do Município, } \\
\text { e obrigação de fazer, para revogar a (s) licença (s) já concedida (s). }\end{array}$ \\
\hline 16.08.2002 & $\begin{array}{l}\text { A Eletroger Ltda. solicitou ao DAIA que fosse mantida a Licença Prévia até } \\
\text { o reexame da matéria objeto da Ação Civil Pública } n^{\circ} 505 / 2001 \text { pelo } \\
\text { Tribunal de Justiça. }\end{array}$ \\
\hline 21.10.2002 & $\begin{array}{l}\text { A Coordenadoria de Licenciamento Ambiental e de Proteção de Recursos } \\
\text { Naturais da SMA expediu Certidão afirmando que a Licença Prévia (i) } \\
\text { possuía prazo de validade de } 5 \text { anos; (ii) contava com } 4 \text { anexos relativos às } \\
\text { exigências que deveriam ser cumpridas; (iii) aprovava a localização e a } \\
\text { concepção de empreendimento, atestando a sua viabilidade ambiental, sem, } \\
\text { contudo, autorizar a implantação. }\end{array}$ \\
\hline 09.06.2003 & $\begin{array}{l}\text { A PGE se manifestou pela revogação da Licença Prévia, em cumprimento } \\
\text { aos termos da sentença judicial. }\end{array}$ \\
\hline
\end{tabular}




\begin{tabular}{|c|c|}
\hline 17.06 .2003 & $\begin{array}{l}\text { A Consultoria Jurídica da SMA encaminhou o processo à Chefia de } \\
\text { Gabinete, com vistas ao imediato cancelamento da Licença Prévia emitida } \\
\text { para a UTE Santa Branca. }\end{array}$ \\
\hline 15.07 .2003 & $\begin{array}{l}\text { O Secretário de Meio Ambiente determinou o cancelamento dessa Licença } \\
\text { Prévia. }\end{array}$ \\
\hline 30.07.2003 & $\begin{array}{l}\text { Foi publicado no Diário Oficial do Estado de São Paulo o cancelamento da } \\
\text { Licença Prévia } n^{\circ} 00470 \text {. }\end{array}$ \\
\hline 03.08 .2003 & $\begin{array}{l}\text { A Eletroger Ltda. protocolou Pedido de Reconsideração/Recurso } \\
\text { Administrativo da decisão que determinou o cancelamento da Licença } \\
\text { Prévia. }\end{array}$ \\
\hline 04.09 .2003 & $\begin{array}{l}\text { A Coordenadoria de Licenciamento Ambiental e de Proteção de Recursos } \\
\text { Naturais da SMA indeferiu o Recurso Administrativo da Eletroger Ltda., } \\
\text { afirmando estar cumprindo a determinação judicial e por ser o ato } \\
\text { administrativo passível do controle judicial. }\end{array}$ \\
\hline 11.09.2003 & $\begin{array}{l}\text { A Procuradoria Geral do Estado exarou o Parecer CJ 462/03, opinando pela } \\
\text { manutenção do cancelamento da Licença Prévia até eventual decisão } \\
\text { judicial em contrário e encaminhando o processo para apreciação do } \\
\text { Governador do Estado. }\end{array}$ \\
\hline 13.10 .2003 & $\begin{array}{l}\text { O Governador do Estado de São Paulo restituiu os autos com parecer } \\
\text { provisório, sugerindo o encaminhamento do processo à Procuradoria Geral } \\
\text { do Estado. }\end{array}$ \\
\hline 28.11.2003 & $\begin{array}{l}\text { A Procuradoria Geral do Estado exarou o Parecer no 414/2003, entendendo } \\
\text { pela manutenção do cancelamento da Licença Prévia. }\end{array}$ \\
\hline 06.02 .2004 & $\begin{array}{l}\text { A Assessoria Jurídica do Governo também se manifestou pela manifestação } \\
\text { do cancelamento da Licença Prévia e retirou a competência decisória do } \\
\text { Governador do Estado. }\end{array}$ \\
\hline 26.04 .2004 & O Governador do Estado confirmou o cancelamento da Licença Prévia. \\
\hline 08.2004 & O processo de licenciamento ambiental da UTE Santa Branca foi arquivado. \\
\hline
\end{tabular}




\section{ANEXO 4}

Síntese do andamento processual da Ação Civil Pública no 42/00

\begin{tabular}{|c|c|}
\hline DATA & ACONTECIMENTO \\
\hline 13.02 .2000 & $\begin{array}{l}\text { O Ministério Público propôs Ação Civil Pública, buscando que a Light } \\
\text { Serviços de Eletricidade S.A. (i) executasse integralmente o Plano de } \\
\text { Recuperação de Áreas Degradadas (PRAD) referente às áreas que foram } \\
\text { degradadas quando da construção da barragem de Santa Branca; (ii) } \\
\text { paralisasse qualquer atividade nas áreas vinculadas à Licença de Instalação } \\
\text { daquele empreendimento; (iii) se abstivesse de dar outra destinação à área que } \\
\text { não a sua plena e inequívoca recuperação ambiental; e (iv) fosse condenada ao } \\
\text { pagamento de multa diária, no valor de } 1.000 \text { salários mínimos por dia de } \\
\text { mora, pelo descumprimento de alguma obrigação de fazer ou não fazer. }\end{array}$ \\
\hline 13.02 .2000 & $\begin{array}{l}\text { O Ministério Público propôs Ação Civil Pública, buscando que a Light } \\
\text { Serviços de Eletricidade S.A. (i) executasse integralmente o Plano de } \\
\text { Recuperação de Áreas Degradadas (PRAD) referente às áreas que foram } \\
\text { degradadas quando da construção da barragem de Santa Branca; (ii) } \\
\text { paralisasse qualquer atividade nas áreas vinculadas à Licença de Instalação } \\
\text { daquele empreendimento; (iii) se abstivesse de dar outra destinação à área que } \\
\text { não a sua plena e inequívoca recuperação ambiental; e (iv) fosse condenada ao } \\
\text { pagamento de multa diária, no valor de } 1.000 \text { salários mínimos por dia de } \\
\text { mora, pelo descumprimento de alguma obrigação de fazer ou não fazer. }\end{array}$ \\
\hline 23.02.2000 & $\begin{array}{l}\text { Deferido o pedido de liminar para que a Light Serviços de Eletricidade S.A. } \\
\text { não desse outra destinação às áreas vinculadas à sua Licença de Instalação, que } \\
\text { não fosse a plena e inequívoca recuperação ambiental, fixado o valor de } 500 \\
\text { salários mínimos por dia no caso de descumprimento da liminar. }\end{array}$ \\
\hline 21.07 .2000 & A Light Serviços de Eletricidade S.A. protocolou a contestação. \\
\hline 07.08 .2000 & O Juízo afastou as preliminares apontadas na contestação. \\
\hline 09.08 .2000 & O Juízo designou audiência de tentativa de conciliação para o dia 29.08.2000. \\
\hline 14.08 .2000 & $\begin{array}{l}\text { A Sociedade Ecológica de Santa Branca requereu ao Juízo seu ingresso no } \\
\text { processo como assistente no pólo ativo da ação. }\end{array}$ \\
\hline 14.08 .2000 & $\begin{array}{l}\text { A Light Serviços de Eletricidade S.A. protocolou petição apontando a carência } \\
\text { da ação por falta de interesse de agir e, caso superada a preliminar, requereu a } \\
\text { antecipação do julgamento da lide. }\end{array}$ \\
\hline 21.08 .2000 & $\begin{array}{l}\text { O Juízo autorizou o ingresso da Sociedade Ecológica de Santa Branca e } \\
\text { determinou a produção de prova pericial, depoimento pessoal do representante } \\
\text { da empresa e oitiva de testemunhas. }\end{array}$ \\
\hline
\end{tabular}




\begin{tabular}{|c|c|}
\hline 24.08.2000 & $\begin{array}{l}\text { A Light Serviços de Eletricidade S.A. protocolou petição requerendo o } \\
\text { indeferimento do ingresso da Sociedade Ecológica de Santa Branca, por falta } \\
\text { de interesse de agir. }\end{array}$ \\
\hline 28.08.2000 & $\begin{array}{l}\text { O Juízo confirmou o ingresso na ação da Sociedade Ecológica de Santa } \\
\text { Branca, pelo fato de ser uma instituição não-governamental e ter interesse } \\
\text { jurídico no deslinde da ação. }\end{array}$ \\
\hline 29.08.2000 & $\begin{array}{l}\text { Foi realizada a audiência de tentativa de conciliação, tendo sido determinada a } \\
\text { suspensão do processo pelo prazo de } 45 \text { dias tendo em vista a possibilidade de } \\
\text { acordo. }\end{array}$ \\
\hline 15.09.2000 & $\begin{array}{l}\text { Light Serviços de Eletricidade S.A. interpôs Agravo de Instrumento contra } \\
\text { decisão que deferiu o pedido de ingresso da Sociedade Ecológica de Santa } \\
\text { Branca como assistente litisconsorcial (processo n }{ }^{\circ} \text { 188.706-5). O recurso foi } \\
\text { julgado em 13.05.2001, tendo o Tribunal mantido a decisão recorrida. }\end{array}$ \\
\hline 29.09.2000 & $\begin{array}{l}\text { Diante da possibilidade de acordo e encerramento da ação, a Light Serviços de } \\
\text { Eletricidade S.A. protocolou petição comprometendo-se a adotar determinadas } \\
\text { medidas preservacionistas. }\end{array}$ \\
\hline 21.10.2000 & \\
\hline 27.11.2000 & $\begin{array}{l}\text { Em complementação à proposta de acordo, a Light Serviços de Eletricidade } \\
\text { S.A. propôs a adoção de um Programa de Educação Ambiental. }\end{array}$ \\
\hline 11.12.2000 & $\begin{array}{l}\text { Foi realizada a audiência de conciliação. A Light Serviços de Eletricidade S.A. } \\
\text { apresentou sua proposta de acordo, acrescentando que arcaria com a } \\
\text { manutenção da creche da comarca local, mas a audiência restou infrutífera. }\end{array}$ \\
\hline 13.12.2000 & $\begin{array}{l}\text { No despacho saneador, o Juízo deferiu o pedido de prova pericial formulado } \\
\text { pelo autor e designou prazo de } 5 \text { dias para indicação de assistente técnico e } \\
\text { apresentação de quesitos. }\end{array}$ \\
\hline 14.12.2000 & $\begin{array}{l}\text { Light Serviços de Eletricidade S.A. protocolou petição requerendo a revogação } \\
\text { da decisão liminar concedida e, alternativamente, requereu em inspeção } \\
\text { judicial nas áreas recuperadas para que, caso fosse constatado o } \\
\text { reflorestamento, fosse revogada a liminar. }\end{array}$ \\
\hline 14.02.2001 & $\begin{array}{l}\text { O perito judicial apresentou sua estimativa de honorários em } \mathrm{R} \$ 12.000,00 \text { e o } \\
\text { descritivo dos trabalhos a serem realizados. }\end{array}$ \\
\hline 23.02.2001 & Light Serviços de Eletricidade S.A. apresentou o seu assistente técnico. \\
\hline 06.04.2001 & $\begin{array}{l}\text { Light Serviços de Eletricidade S.A. informou o Juízo sobre a interposição do } \\
\text { Agravo Retido contra a decisão que determinava o depósito dos honorários } \\
\text { periciais, fixados em } \mathrm{R} \$ 12.000,00 \text {. }\end{array}$ \\
\hline 18.06.2001 & $\begin{array}{l}\text { A Sociedade Ecológica de Santa Branca requereu que a Light Serviços de } \\
\text { Eletricidade S.A. desistisse publicamente e perante a SMA de instalar seu } \\
\text { empreendimento na área, sob pena de multa de } 500 \text { salários mínimos por dia, e } \\
\text { que a SMA, o Consema, o DAIA e demais órgãos licenciadores fossem } \\
\text { oficiados para paralisar o processo de licenciamento da UTE. }\end{array}$ \\
\hline
\end{tabular}




\begin{tabular}{|c|c|}
\hline 22.08.2001 & $\begin{array}{l}\text { O perito apresentou o laudo e uma adequação dos seus honorários para R\$ } \\
19.980,00 \text {. }\end{array}$ \\
\hline 27.08.2001 & $\begin{array}{l}\text { O Ministério Público apresentou quesitos para o perito e requereu que fosse } \\
\text { intimado para comparecer em audiência. }\end{array}$ \\
\hline 28.08.2001 & $\begin{array}{l}\text { Diante do teor do laudo pericial, a Light Serviços de Eletricidade S.A. } \\
\text { requereu a revogação da liminar (periculum in mora reverso). }\end{array}$ \\
\hline 30.08.2001 & $\begin{array}{l}\text { O Juízo despachou que (i) não lhe caberia deliberar a respeito do } \\
\text { prosseguimento do licenciamento ambiental; (ii) os fatos narrados pela } \\
\text { Sociedade Ecológica de Santa Branca não demonstravam o descumprimento } \\
\text { da medida liminar, indeferindo o pedido de pagamento de multa; e (iii) o } \\
\text { pedido de revogação da liminar já havia sido apreciado na ocasião do despacho } \\
\text { saneador e a juntada do laudo pericial não teve o condão de alterar a decisão } \\
\text { exarada. }\end{array}$ \\
\hline 05.09.2001 & $\begin{array}{l}\text { Light Serviços de Eletricidade S.A. interpôs recurso de Agravo de Instrumento } \\
\text { com pedido de efeito suspensivo contra a parte da decisão que manteve a } \\
\text { liminar concedida (Processo }{ }^{\circ} 246.807-5 \text { ). }\end{array}$ \\
\hline 25. 09.2001 & $\begin{array}{l}\text { Sociedade Ecológica de Santa Branca se manifestou sobre o laudo pericial que } \\
\text { concluiu pela não ocorrência de impactos ambientais com a instalação da } \\
\text { Termoelétrica e juntou estudos da Universidade de Campinas, da Universidade } \\
\text { de São Paulo e do Instituto Nacional de Pesquisas Espaciais (INPE). }\end{array}$ \\
\hline 20.10.2001 & $\begin{array}{l}\text { A Prefeitura Municipal de Santa Branca requereu a imediata suspensão da } \\
\text { medida liminar (Processo } 88.881-0 / 3 \text { ). }\end{array}$ \\
\hline 20.11.2001 & O Tribunal de Justiça, deferiu o pedido de suspensão da liminar. \\
\hline 14.12.2001 & $\begin{array}{l}\text { O assistente técnico da Light Serviços de Eletricidade S.A. requereu a juntada } \\
\text { de seu laudo técnico. }\end{array}$ \\
\hline 20.02.2002 & $\begin{array}{l}\text { Sociedade Amigos de Bairro } D^{\prime} \text { Angola requereu o seu ingresso como } \\
\text { assistente litisconsorcial do autor. }\end{array}$ \\
\hline 25.02.2002 & $\begin{array}{l}\text { Light Serviços de Eletricidade S.A. requereu o indeferimento do ingresso da } \\
\text { Sociedade Amigos de Bairro D’Angola no processo. }\end{array}$ \\
\hline 26.03.2002 & $\begin{array}{l}\text { Juízo autorizou o ingresso da Sociedade do Bairro D’Angola como assistente } \\
\text { litisconsorcial do autor. }\end{array}$ \\
\hline 26.03.2002 & $\begin{array}{l}\text { O Tribunal de Justiça deu provimento as Agravo de Instrumento interposto } \\
\text { pela Light Serviços de Eletricidade S.A. (Processo } n^{\circ} 246-807-5 \text { ) e revogou a } \\
\text { liminar proibitiva do processamento de estudo para licenciamento do projeto } \\
\text { da UTE Santa Branca na parte do terreno objeto do PRAD. }\end{array}$ \\
\hline 01.04 .2002 & $\begin{array}{l}\text { Light Serviços de Eletricidade S.A. protocolou Agravo Retido contra decisão } \\
\text { que autorizou o ingresso da Sociedade do Bairro D’Angola na ação. }\end{array}$ \\
\hline 15.07.2002 & $\begin{array}{l}\text { Juízo julgou procedentes os pedidos formulados na inicial, condenando a Light } \\
\text { Serviços de Eletricidade S.A. ao cumprimento da obrigação de fazer, para que } \\
\text { executasse integralmente o PRAD, devendo iniciar o processo de recuperação }\end{array}$ \\
\hline
\end{tabular}




\begin{tabular}{|c|c|}
\hline & $\begin{array}{l}\text { em } 6 \text { meses, sendo supervisionado por órgãos ambientais; e condenação em } \\
\text { obrigação de não fazer, consistente em abster-se de dar outra destinação à área } \\
\text { e paralisar qualquer atividade que não fosse a plena e inequívoca recuperação } \\
\text { ambiental, fixando a multa diária no valor de } 1.000 \text { salários mínimos em casos } \\
\text { de descumprimento da decisão. }\end{array}$ \\
\hline 01.08 .2002 & $\begin{array}{l}\text { Light Serviços de Eletricidade S.A. opôs Embargos de Declaração, por não ter } \\
\text { a sentença se manifestando a respeito do adiantamento de custas. }\end{array}$ \\
\hline 29.08.2002 & Juízo rejeitou os Embargos de Declaração. \\
\hline 29.08.2002 & $\begin{array}{l}\text { Light Serviços de Eletricidade S.A. interpôs recurso de Apelação contra a } \\
\text { sentença do Juízo de Santa Branca (Processo n }{ }^{\circ} 308.911-5 / 1 \text { ). }\end{array}$ \\
\hline 29.11.2005 & $\begin{array}{l}\text { A Apelação da Light Serviços de Eletricidade S.A. foi julgada pela } 1^{\text {a }} \text { Câmara } \\
\text { de Direito Público do Tribunal de Justiça e, vencido em parte o } 3^{\circ} \text { juiz, os } \\
\text { Desembargadores deram provimento ao recurso. }\end{array}$ \\
\hline 03.02.2006 & $\begin{array}{l}\text { O Ministério Público opôs Embargos Infringentes e, em 08.02.2006, a } \\
\text { Sociedade Ecológica de Santa Branca interpôs também recurso. }\end{array}$ \\
\hline 21.03.2006 & $\begin{array}{l}\text { Light Serviços de Eletricidade S.A. protocolou contra-razões aos Embargos } \\
\text { infringentes. }\end{array}$ \\
\hline 29.08.2006 & $\begin{array}{l}\text { Foram julgados os embargos infringentes (intimação do acórdão em } \\
24.10 .2006 \text { ), os quais, por maioria, foram acolhidos, entendendo-se pela } \\
\text { procedência da Ação Civil Pública. }\end{array}$ \\
\hline 27.10.2006 & Light Serviços de Eletricidade S.A. opôs embargos de declaração. \\
\hline 11.01.2007 & $\begin{array}{l}\text { O Tribunal de Justiça rejeitou os embargos de declaração da Light Serviços de } \\
\text { Eletricidade S.A. }\end{array}$ \\
\hline 24.01.2007 & Light Serviços de Eletricidade S.A. protocolou Recurso Especial. \\
\hline 15.02.2007 & $\begin{array}{l}\text { Foi publicada decisão proferida pelo Desembargador indeferindo o pedido de } \\
\text { extração de Carta de Sentença. }\end{array}$ \\
\hline 26.02.2007 & Foi determinado o sobrestamento do Recurso Especial. \\
\hline 25.04.2007 & $\begin{array}{l}\text { Foi publicado despacho em que foi aberta vista dos autos à parte contrária para } \\
\text { apresentar contra-razões de Recurso Especial, no prazo de } 30 \text { dias. }\end{array}$ \\
\hline 29.05.2007 & Foram apresentadas as contra-razões de Recurso Especial. \\
\hline 05.07.2007 & $\begin{array}{l}\text { Os autos foram remetidos à conclusão para o Presidente da Seção de Direito } \\
\text { Público. }\end{array}$ \\
\hline 15.08.2007 & $\begin{array}{l}\text { Publicada decisão em que o Presidente da Seção de Direito Público } \\
\text { determinou a subida dos autos do Recurso Especial para o Superior Tribunal } \\
\text { de Justiça. }\end{array}$ \\
\hline 28.08.2007 & $\begin{array}{l}\text { Os autos do Recurso Especial foram recebidos na Coordenaria de Recursos } \\
\text { Especiais do STJ e registrados sob o } \mathrm{n}^{\circ} 982.134 \text {. }\end{array}$ \\
\hline 24.09.2007 & $\begin{array}{l}\text { O Recurso Especial foi distribuído à Ministra Relatora Eliana Calmon da } 2^{\mathrm{a}} \\
\text { Turma do Superior Tribunal de Justiça. }\end{array}$ \\
\hline
\end{tabular}




\begin{tabular}{|l|l|}
\hline 22.04.2008 & $\begin{array}{l}\text { Resultado de julgamento final: "a Turma, por unanimidade, negou provimento } \\
\text { ao recurso, nos termos do voto do(a) sr(a). Ministro(a)-Relator(a)." }\end{array}$ \\
\hline 23.05 .2008 & Protocolada petição para embargos de divergência. \\
\hline 27.05 .2008 & Desistência dos embargos de divergência. \\
\hline 29.07 .2008 & $\begin{array}{l}\text { Decisão transitada em julgado e processo encaminhado para baixa definitiva } \\
\text { ao Tribunal de Justiça de São Paulo }\end{array}$ \\
\hline 13.10 .2009 & Fase de execução de sentença, aguardando vistoria da Cetesb na área. \\
\hline
\end{tabular}


ANEXO 5

Síntese do andamento processual da Ação Civil Pública n 505/01

\begin{tabular}{|c|c|}
\hline DATA & ACONTECIMENTO \\
\hline 20.11.2001 & $\begin{array}{l}\text { O Ministério Público do Estado de São Paulo propôs Ação Civil Pública } \\
\text { contra a Fazenda do Estado de São Paulo buscando: (i) que não fosse } \\
\text { concedida as licenças prévias, de instalação e de operação para a UTE Santa } \\
\text { Branca; (ii) revogar a(s) licença(s) já concedida(s); (iii) o pagamento de multa } \\
\text { diária no valor de } 1.000 \text { salários míninos por dia, por descumprimento das } \\
\text { obrigações. }\end{array}$ \\
\hline 21.11.2001 & $\begin{array}{l}\text { Juízo determinou a intimação da Fazenda Pública do Estado de São Paulo para } \\
\text { se manifestar quanto ao pedido de concessão de liminar. }\end{array}$ \\
\hline 21.12.2001 & $\begin{array}{l}\text { A Fazenda Pública requereu a extinção do processo pela carência da ação e, } \\
\text { alternativamente, que a Eletroger Ltda. fosse incluída no pólo passivo da } \\
\text { demanda. }\end{array}$ \\
\hline 26.12.2001 & $\begin{array}{l}\text { Juízo indeferiu o pedido de liminar, por não vislumbrar os requisitos } \\
\text { necessários para a concessão da medida requerida. }\end{array}$ \\
\hline 04.02 .2002 & $\begin{array}{l}\text { O Ministério Público apontou argumentos contrários à deliberação do } \\
\text { Consema em sua } 69^{\mathrm{a}} \text { Reunião extraordinária e reiterou o pedido de } \\
\text { deferimento da liminar. }\end{array}$ \\
\hline 13.02 .2002 & $\begin{array}{l}\text { Com base nessa manifestação do Ministério Público, o Juízo deferiu o pedido } \\
\text { de liminar consistente na suspensão do licenciamento ambiental no prazo e } \\
120 \text { dias, sob pena de multa diária, equivalente a } 1.000 \text { salários mínimos pelo } \\
\text { descumprimento. }\end{array}$ \\
\hline 05.03 .2002 & A Fazenda do Estado de São Paulo contestou a ação. \\
\hline 11.03 .2002 & $\begin{array}{l}\text { A Light Serviços de Eletricidade S.A. e a Eletroger Ltda. interpuseram recurso } \\
\text { de Agravo de Instrumento contra decisão que deferiu a suspensão do } \\
\text { licenciamento (Processo } \mathrm{n}^{\circ} \text { 263.250-5). }\end{array}$ \\
\hline 01.04 .2002 & $\begin{array}{l}\text { O Desembargador Relator negou o feito suspensivo pleiteado no Agravo de } \\
\text { Instrumento, decisão contra a qual foi interposto Agravo Regimental. }\end{array}$ \\
\hline 12.08.2002 & $\begin{array}{l}\text { Os Desembargadores julgaram prejudicados os recursos, pela perda do objeto } \\
\text { recursal, ante a superveniência da sentença de procedência integral da ação } \\
\text { civil pública contra as recorrentes. }\end{array}$ \\
\hline 03.04 .2002 & O Juízo reiterou a manutenção da decisão agravada. \\
\hline 11.04 .2002 & Eletroger Ltda. contestou a ação e apresentou impugnação ao valor da causa. \\
\hline 26.04 .2002 & Light Serviços de Eletricidade S.A. contestou a ação. \\
\hline 03.05 .2002 & O Ministério Público apresentou sua réplica. \\
\hline
\end{tabular}




\begin{tabular}{|c|c|}
\hline 21.05.2002 & $\begin{array}{l}\text { O Juízo ordenou que as partes especificassem as provas que pretendiam } \\
\text { produzir. }\end{array}$ \\
\hline 27.05.2002 & $\begin{array}{l}\text { Eletroger Ltda. apontou a desnecessidade de produção de provas e o Promotor } \\
\text { de Justiça requereu a antecipação do julgamento da lide. }\end{array}$ \\
\hline 12.12.2002 & $\begin{array}{l}\text { Light Serviços de Eletricidade S.A. manifestou o seu desinteresse em produzir } \\
\text { provas e ressalvou o direito de apresentar seu rol de testemunhas. }\end{array}$ \\
\hline 19.06.2002 & $\begin{array}{l}\text { A Fazenda Pública concordou com a impugnação ao valor da causa } \\
\text { apresentada pela Eletroger Ltda. }\end{array}$ \\
\hline 19.06.2002 & A Fazenda Pública requereu o julgamento antecipado da lide. \\
\hline 01.07 .2002 & $\begin{array}{l}\text { O Juízo rejeitou a impugnação ao valor da causa. Na mesma data, julgou } \\
\text { procedentes os pedidos constantes da inicial, condenando a Fazenda Pública na } \\
\text { obrigação de não fazer, consistente em abster-se de conceder as licenças } \\
\text { prévias, de instalação e de operação para a UTE Santa Branca nas áreas } \\
\text { abrangidas pelo artigo } 166 \text { da Lei Orgânica do Município, e obrigação de } \\
\text { fazer, para revogar a (s) licença (s) já concedida (s), fixando multa diária no } \\
\text { valor de } 1.000 \text { salários mínimos por dia, por descumprimento da decisão. }\end{array}$ \\
\hline 08.07.2002 & A Fazenda Pública propôs Embargos de Declaração. \\
\hline 17.07.2002 & $\begin{array}{l}\text { Juízo remeteu o processo ao Tribunal de Justiça, para análise da matéria } \\
\text { alegada nos Embargos da Fazenda. }\end{array}$ \\
\hline 19.07.2002 & Light Serviços de Eletricidade S.A. opôs Embargos de Declaração. \\
\hline 19.07.2002 & $\begin{array}{l}\text { Eletroger Ltda. interpôs Agravo de Instrumento com pedido de efeito } \\
\text { suspensivo contra decisão que julgou procedente o valor da causa em } \mathrm{R} \$ \\
1.200 .000 .000,00 \text { (Processo } \mathrm{n}^{\circ} 284.573-5 \text { ). }\end{array}$ \\
\hline 22.07 .2002 & Juízo rejeitou os Embargos opostos pela Light Serviços de Eletricidade S.A. \\
\hline 22.07 .2002 & Eletroger Ltda. opôs Embargos de Declaração. \\
\hline 23.07.2002 & Juízo rejeitou os Embargos opostos pela Eletroger Ltda. \\
\hline 29.07.2002 & $\begin{array}{l}\text { Tribunal de Justiça julgou o Agravo de instrumento interposto pela Eletroger } \\
\text { Ltda. (Processo } \mathrm{n}^{\circ} \text { 284.573-5), e concedeu efeito suspensivo parcial para } \\
\text { suspensão do processo até o julgamento do recurso que impugnou o valor da } \\
\text { causa. }\end{array}$ \\
\hline 05.08 .2002 & A Fazenda Pública do Estado de São Paulo apelou da decisão final. \\
\hline 17.05.2002 & Eletroger Ltda. apelou da decisão final (Processo no 408.001-5/8). \\
\hline 06.04 .2004 & $\begin{array}{l}\text { O Tribunal de Justiça deu parcial provimento ao Agravo de Instrumento } \\
\text { (Processo } 284.573-5 \text { ), determinado que o MM. Juízo arbitrasse o valor da } \\
\text { causa em R } \$ 500.000,00 \text {. }\end{array}$ \\
\hline 01.12 .2004 & $\begin{array}{l}\text { Os recursos de Apelação interpostos pela Eletroger Ltda. e Fazenda foram } \\
\text { recebidos em seu efeito devolutivo e o MM. Juízo de Santa Branca remeteu os } \\
\text { autos ao Tribunal de Justiça. }\end{array}$ \\
\hline 29.05.2005 & O processo foi encaminhado para a Procuradoria de Justiça. \\
\hline
\end{tabular}




\begin{tabular}{|c|c|}
\hline 01.02 .2007 & Eletroger Ltda. apresentou petição requerendo a localização dos autos. \\
\hline 16.02.2007 & $\begin{array}{l}\text { Foi expedido pelo Serviço de Processamento de acervo de Direito Público o } \\
\text { Ofício 37/2007 ao Ministério Público, requerendo a remessa do processo. }\end{array}$ \\
\hline 23.04.2007 & $\begin{array}{l}\text { O processo foi distribuído ao Desembargador Guerrieri Rezende, da } 7^{\mathrm{a}} \text { Câmara } \\
\text { de Direito Público. }\end{array}$ \\
\hline 02.05 .2007 & Os autos foram recebidos em cartório com despacho. \\
\hline 21.05.2007 & $\begin{array}{l}\text { Foi publicado despacho em que se determinou a redistribuição do processo } \\
\text { para a Câmara Especial do Meio Ambiente do Tribunal. }\end{array}$ \\
\hline 24.07 .2007 & $\begin{array}{l}\text { O processo foi distribuído à Câmara Especial do Meio Ambiente do Tribunal } \\
\text { de Justiça do Estado de São Paulo. }\end{array}$ \\
\hline 26.07.2007 & $\begin{array}{l}\text { Os autos foram distribuídos à Desembargadora Regina Capistrano da } 1^{\text {a }} \\
\text { Câmara de Especial de Meio Ambiente. }\end{array}$ \\
\hline 31.07.2008 & Foi dado provimento aos recursos. \\
\hline 18.02.2009 & Essa decisão transitou em julgado no Tribunal de Justiça. \\
\hline 19.03 .2009 & $\begin{array}{l}\text { O Juízo da Comarca de Santa Branca despachou que fossem cumpridos os } \\
\text { termos da decisão do Tribunal de Justiça e manda ouvir as partes. }\end{array}$ \\
\hline 06.07.2009 & Determinado o arquivamento do processo. \\
\hline
\end{tabular}




\section{ANEXO 6 \\ Referências sintéticas sobre os entrevistados citados no trabalho}

(em ordem alfabética)

\section{Carlos Alberto de Salles}

Promotor de Justiça de Meio Ambiente no Ministério Público do Estado de São Paulo na Capital. Ingressou no Ministério Público em 1988. Atualmente ocupa cargo em $2^{\mathrm{a}}$ instância, na Procuradoria de Direitos Difusos e Coletivos. Professor Doutor do Departamento de Direito Processual da Faculdade de Direito da Universidade de São Paulo, também integrante do corpo docente da Escola Superior do Ministério Público de São Paulo, entre outros, sua dissertação de Mestrado refere-se à legitimação do Ministério Público para a defesa de direitos e garantias constitucionais. Foi entrevistado em 08.10.2009.

\section{Clério Rodrigues da Costa}

Procurador do Estado, ingressou na carreira em 1988. Atualmente está lotado na $1^{\text {a }}$ Subprocuradoria do Contencioso Ambiental dessa Procuradoria, por onde passam as ações civis públicas ambientais propostas em face da Fazenda Pública na Capital em primeira instância e todas do Estado em grau recursal. Como representante da Procuradoria Geral do Estado, é membro suplente no Conselho Estadual do Meio Ambiente e, nessa condição, participa dos plenários desse Conselho desde a inclusão daquela instituição no Consema (o que ocorreu em função do Decreto 53.027, de 26.05.2008). Foi entrevistado em 10.08.2009. 


\section{Daniel Fink}

Procurador de Justiça e ex-Promotor de Justiça de Meio Ambiente no Ministério Público do Estado de São Paulo da Capital. Ingressou nessa instituição em 1988. Foi coordenador do Centro de Apoio Operacional de Meio Ambiente e Urbanismo do Ministério Público paulista, entre fevereiro de 2003 a setembro de 2005; nesse período houve a unificação do Centro Operacional de Meio Ambiente com o de Habitação e Urbanismo. Autor de livros sobre licenciamento ambiental. Foi entrevistado em 10.08.2009.

\section{Fernando Cardozo Fernandes Rei}

Presidente da Cetesb desde 2007, tendo ocupado esse cargo anteriormente entre 2001 e 2002. Na Cetesb, exerceu ainda as seguintes funções: Assistente Executivo de 1995 a 1997, Diretor de Desenvolvimento e Transferência de Tecnologia de 1997 a 1999 e depois entre 2001 e 2003, e Diretor de Controle da Poluição Ambiental de 2002 a 2003. Durante esses períodos foram introduzidas alterações legislativas no Decreto Estadual 8.468/76, no que se refere ao licenciamento ambiental, além da reestruturação na Secretaria de Meio Ambiente e na Cetesb. É professor de gestão ambiental no Senac. Foi entrevistado em 16.12.2008.

\section{Germano Seara Filho}

Secretário Executivo do Conselho Estadual do Meio Ambiente desde novembro de 1991. Anteriormente, dentro da Secretaria de Meio Ambiente do Estado de São Paulo, foi gerente da Gerência de Educação e Participação da Cetesb e coordenador da Coordenadoria de Educação Ambiental. Como secretário executivo, é de sua responsabilidade, entre outras atribuições, agendar e preparar as reuniões do Consema e das audiências públicas relacionadas a licenciamento ambiental. Conduziu as quatro audiências públicas realizadas para a discussão da UTE Santa Branca. A entrevista foi realizada em 15.11.2008. 


\section{José Goldemberg}

Ex-Secretário de Meio Ambiente do Estado de São Paulo, no período de 2002 a 2006. Durante sua gestão, por determinação judicial, foram canceladas duas licenças ambientais concedidas pela Secretaria de Meio Ambiente a empreendimentos de geração de energia elétrica, entre as quais a UTE Santa Branca. Professor titular aposentado da Faculdade de Física da Universidade de São Paulo, professor do Instituto de Energia e Eletricidade da mesma Universidade. A entrevista foi realizada em 17.12.2008.

\section{José Manoel Mondelo}

Engenheiro, consultor técnico na área ambiental, foi chefe da equipe da Jäakko Poyry Tecnologia Ltda., consultoria técnica contratada pela Eletroger Ltda. para elaborar os estudos ambientais voltados para o licenciamento ambiental da UTE Santa Branca, bem como para a interface técnica com o órgão de gestão ambiental, inclusive nas audiências públicas, no plenário do Consema e na Promotoria de Justiça de Santa Branca. Também trabalhou no licenciamento ambiental de outros empreendimentos de geração de energia elétrica à época, tais como Duke Energy e Capuava Cogeração. A entrevista foi realizada em 07.01.2009.

\section{Maria Assunção Faus da Silva Dias}

Professora Titular do Instituto de Astronomia, Geofísica e Ciências Atmosféricas da Universidade de São Paulo (IAG-USP), coordenadora do Instituto Nacional de Pesquisa Espacial (INPE), além de colaboradora de Institutos brasileiros, americanos e suecos de pesquisa em ciências atmosféricas. Pelo IAG-USP, coordenou os estudos de modelagem sobre os efeitos atmosféricos que adviriam da instalação da UTE Santa Branca ao Município e à região. Esteve presente em audiência pública e em reunião na Promotoria de Justiça de Santa Branca. A entrevista foi realizada em 22.12.2008. 